Andrews University

Digital Commons @ Andrews University

1980

\title{
A Process of Self-Assessment and Goal Setting for a Latin American Local Congregation as a Possible Means To Create the Necessary Conditions for Church Renewal, Fruitful Evangelism, and Effective Nurture
}

Ruben Pereyra

Andrews University

Follow this and additional works at: https://digitalcommons.andrews.edu/dmin

Part of the Practical Theology Commons

\section{Recommended Citation}

Pereyra, Ruben, "A Process of Self-Assessment and Goal Setting for a Latin American Local Congregation as a Possible Means To Create the Necessary Conditions for Church Renewal, Fruitful Evangelism, and Effective Nurture" (1980). Professional Dissertations DMin. 567.

https://dx.doi.org/10.32597/dmin/567

https://digitalcommons.andrews.edu/dmin/567

This Project Report is brought to you for free and open access by the Graduate Research at Digital Commons @ Andrews University. It has been accepted for inclusion in Professional Dissertations DMin by an authorized administrator of Digital Commons @ Andrews University. For more information, please contact repository@andrews.edu. 


\begin{abstract}
A PROCESS OF SELF-ASSESSMENT AND GOAL SETTING FOR A LATIN-AMERICAN LOCAL CONGREGATION AS A POSSIBIE MEANS TO CREATE THE NECESSARY CONDITIONS FOR CHURCH RENEWAL, FRUITFUL EVANGELISM, AND EFFECTIVE. NURTURE

by

Ruben Pereyra
\end{abstract}

Chairperson: Werner Vyhmeister 


\title{
ABSTRACT OF GRADUATE STUDENT RESEARCH \\ Project Report
}

\author{
Andrews University \\ Seventh-day Adventist Theological Seminary
}

Title: A PROCESS OF SELF-ASSESSMENT AND GOAL SETTING FOR A LATINAMERICAN LOCAI, CONGREGATION AS A POSSIBLE MEANS TO CREATE THE NECESSARY CONDITIONS FOR CHURCH RENEWAL, FRUITFUL EVANGELISM, AND EFFECTIVE NURTURE

Name of researcher: Ruben Pereyra

Name and title of faculty adviser: Werner Vyhmeister, Ph.D. Date completed: May 1980

\section{Problem}

Dropouts from church membership have increased during the 1960s among Christian denominations. Abundant literature has been circulating analyzing possible causes and suggesting remedies. The picture is not yet clear. Meanwhile, several types of solutions have been proposed and tried with different degrees of success or failure.

As the issue is also a concern among Seventh-day Adventists, a program considering the particular situation of this denomination, 
in a Latin-American setting, is presented. One way to a renewal experience that would help confirm members and thus prevent dropouts. is suggested.

\section{Method}

As a first step, a review of the current literature has been made to evaluate the different suggestions given and methods used to increase accessions and reduce apostasies. Further, a program based on a self-assessment process and followed by goal setting and continuous evaluation that can be applied to a local congregation is out1ined.

The thesis of the project has been tested in two local congregations of Texas. In order to search for areas where improvement is necessary, three different surveys were conducted among present and former members of the participating congregations. The analysis of findings of these experiences is made in the project; some conclusions have been drawn and these are éstimated as applicable also to other circumstances and situations.

\section{$\underline{\text { Results }}$}

By the end of the program, the churches involved in the pilot test had a clear idea of their needs and had outlined ways and means to satisfy them. The goal setting became the starting point for a reformation in the life of the congregations. According to the studies conducted, improving fellowship, the quality of worship, and preaching were among the priorities of the congregations involved. 


\section{Conc1usions}

After the literature about the issue was reviewed and the field tests were conducted, a twofold remedy for facing the problem of dropouts was proposed: (1) the church family must discover a true picture of itself and search for identification of weak areas, and (2) a dedicated effort must be made to face the shortcomings and search for improvement.

The renewal of the internal climate of the church, the quality of relationship among members, and an improvement of the quality of worship and preaching would transform the congregation into a source of spiritual power and affirmation. This, would result in more accessions and fewer apostasies. 
Andrews University

Seventh-day Adventist Theological Seminary

A PROCESS OF SELF-ASSESSMENT AND GOAL SETTING FOR A LATIN-AMERICAN LOCAL CONGREGATION AS A POSSIBLE MEANS TO CREATE THE NECESSARY CONDITTONS FOR CHURCH'RENEWAL, FRUITFUL EVANGELISM, AND EFFECT IVE NURTURE

A Project Report

Presented in Partial Fulfillment

of the Requirements for the Degree

Doctor of Ministry

by

Ruben Pereyra

May 1980 



\section{DEDICAT ION}

Because Eliana my wife, and Magaly, Mirna, Susy, and Brenda, my daughters, have meant so much to me and my ministry through the years as pastor and traveling evangelist, for their constant support and love, I warmly dedicate to them this project as a humble way of saying again, Thank you. 
TABLE OF CONTENTS

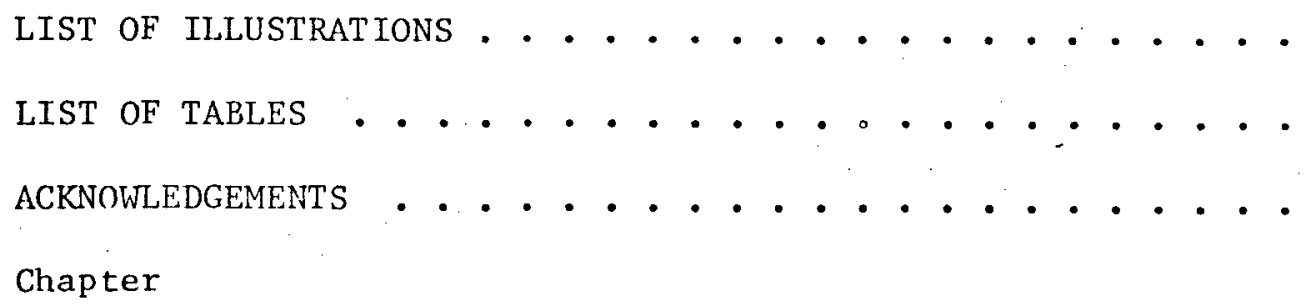

I. INTRODUCTION ................... 1

Background .................... 1

Purpose and Objectives ..............

Limitations...................... . . . . . . . . . . 4

Overview of the Study . . . . . . . . . . . 4

Definition of Terms............... 5

II. THE DIMENSIONS OF THE CHURCH . . . . . . . . . . 8

Human and Divine .............. . . 10

The Church as a Divine Organism . . . . . . 13

The Body of Christ . . . . . . . . . 13

The Bride. . . . . . . . .... 17

The Church as a Human Organization . . . . . . 18

The Church and the World . . . . ....... 20

The Process of Accommodation . . . . . . . . 26

An Analysis of the Process of Accommodation . . . 31

Practical Consequences of This Accommodation . . . 36

III. RENEWAL AS A REMEDY FOR THE PROBLEM OF DROPOUTS . . • • 38

Introduction . . . . . . . . . . . . 38

The SDA Church and Dropouts .......... . 39

What is Renewal . . . . . . . . . . 45

IV. THE SELF-ASSESSMENT PROGRAM . . . . . . . . . . . 50

Objectives of the Process . . . . . . . . 50

Planning with the Church ........... 55

Steps in the Process . . . . . . . ... . 55

Subjective Self-Evaluation of the Members . . . . 56

Interview with Disfellowshipped and Inactive

Members ................ 57

Survey among Members ............. 61

Study Groups ................ 62

Implementation of the Suggestions . . . . . . 65

Continuous Evaluation . . . . . . . . . . 69 
Chapter

V. ANALYSIS OF THE TEXAS EXPERIMENT . . . . . . . .

The Churches Studied . . . . . . . . . .

Dallas, The Oak Cliff Church . . . . . . 72

Houston, The Robertson Church . . . . ... 74

The Process of Self-Assessment . . . . . . . 74

Step 1. Personal Analysis .......... 74

Step 2. Visitation of Backsliders . . . . . . 81

Step 3. Survey among Members . . . . . . 81

The respondents . . . . . . . . . . 83

The Evaluation of the Church . . ....... 85

Step 4. Study Groups . . . . . . . . . . 104

Preliminary Organization .......... 105

Selection of leaders ............ . . 106

Members of the groups . . . . . . . . . 106

Time available .............. 108

Reports ............... 108

VI. INTENTIONALITY IN THE LIFE OF. THE CONGREGATION • • • 109

Need of Intentionality . . . . . . . . . 109

Analysis of the Reports . . . . . . . . . 112

Report of Group 1--Dallas . . ......... . 113

Analysis of the report of group 1--Dallas . . . 116

Reports of Groups 2-6--Dallas: A Brief Analysis • 117

Report 2--Worship and adoration . . . . . . 118

Report 3--Preaching ............ 118

Report 4--Outreach program .......... 120

Report 5--Prayer meeting ......... 120

Report 6--The church and money . . . . . 121

Report of Group 2--Houston . . . . . . . . 122

Text of Report 2--Worship and adoration . . . . 122

Implementing the Suggestions . . . . . . . . 124

Setting of priorities......... 125

Suggestions transformed into goals .. . . . . 125

Planning and Acting ........... 127

Evaluation ............. . . 127

VII. SUMMARY AND CONCLUSIONS . . . . . . . . . . . 128

Summary . . . . . . . . . . ... . 128

The Program Proposed . . . . . . . . 128

The Field Test .............. 129

Conclusions . . . . . . . . . . 130

Solutions . . . . . . . . . . . . 132

Application of the program . . . . . . . . 133

For Further Study ............... 135

APPENDIX A: The Instruments . . . . . . . . . . 136

B: Suggested Topics for the Study Groups . . . . 147

C: Results of the Survey among Members . . . . . 156

D: Reports of the Study Groups 2 to 6--Dallas . . . 178

SELECTED BIBLIOGRAPHY . . . . . . . . . . . . . 187 


\section{LIST OF ILLUSTRATIONS}

1. The Relationship between the Church and the World . • 22

2. The Relationship between the Church and the World . . 23

3. Two-step Cycle for a Self-assessment and

Goal-setting Process . . . . . . . . . . 71

4. Results of the Personal Analysis--Dallas . . . . . 77

5. Results of the Personal Analysis-Houston . . . . . 78

6. Personal Analysis--Comparison between Dallas and Houston .................. . . 80

7. Evaluation of the Quality of Four Aspects of the Internal Environment of the Church, Dallas and Houston .................... 90

8. The Continuous Cycle that Gives Intentionality to the Life of the Church . . . . . . . . . . 111 
1. Accessions and Dropouts in the SDA Church in North America, 1976-78 ............... 39

2. Accessions and Dropouts in the SDA Church in the World Field, 1976-78 .............. 40

3. A Comparison of Highest Ranking Factors Contributing to Disassociation from the Church as Expressed in Percentage by Former Members (FM), Adventist Pastors (AP), Denominational Leaders (DL), and

4. Causes for Disassociation Given by Backsididers in Different Countries of South America. . . . . . . 44

5. Present Age of the Respondents of the Survey in Dallas and Houston ............... 83

6. Age of Baptism of the Respondents of the Survey in Dallas and Houston ... . . . . . . . 85

7. Means by Which the Respondents Came to the Church . . 86

8. Religious Background of the Respondents . . . . . . 86

9. What Most Impressed Newcomers . . . . . . . . . 87

10. Evaluation of the Degree of Enjoyment of Participants in the General Activities of the Church . . . . . 88

11. Evaluation of the Degree of Effectiveness of the Programs of the Church . . . . . . . . . 89

12. Causes for Loss of Interest and Dropout, as Given by Present Members of the Church . . . ...... 91

13. Evaluation of Reverence in the Church . . . . . . . 92

14. Evaluation of Quality of Worship Services . . . . . . 93

15. Feeling of God's Presence at the Services . . . . . 93

16. Evaluation of Preaching . . . . . . . . . . . 94

17. Regular Attendance at the Three Main Weekly Services of the Church ................. 95

18. Comparison of Attitudes and Evaluation between Two Age Groups: 16-25 and 26-30 Years 01d ...... 100

19. Attendance at the Study Groups in Dallas . . . . . 107 


\section{ACKNOWLEDGEMENTS}

The writer is indebted to many people who have contributed to the completion of this project.

Special recognition should be given to Dr. Werner Vyhmeister, the Chairman of the Doctoral Committee, whose friendship, patience, and expertise have been a constant source of encouragement during the entire process. To Dr. Nancy Vyhmeister for the valuable suggestions given, to Dr. Arnold Kurtz for his guidance and editorial help, cheerfully given in spite of his busy schedule, special thanks are given. Gratitude is also expressed to the other members of the committee: Dr. W. G. C. Murdoch and Dr. Leona Running, for their help in the revision of the material and for their suggestions.

This project, and the whole course, have been made possible by the constant support of the South American Division of Seventhday Adventists and the Chile Union, to whom a word of thanks is imperative. Also to the Texas Conference, that made possible and supported the field test conducted in its territory.

Jane Hutapea fulfilled an almost impossible task transforming the handwritten material into a first draft, and Kathryn Cash made the final copy and gave additional editorial suggestions. To them, many thanks.

The merits this project might have are to the credit of all of those named above and many others who in one way or another contributed to its completion. 
CHAPTER I

INTRODUCTION

\section{Background}

During 1974 more than thirty thousand nembers of the Seventh-day Adventist churches in the eight countries of the South American Division were disfellowshipped. This number did not represent dropouts occuring during a single year, but was primarily the result of an updating of church membership records. At the time, the writer was serving as Ministerial Secretary of the Division and because of the impact it made upon him, he began a study of the problem in an attempt to discover its causes and to develop possible remedies.

The "Good Shepherd Plan," as it was termed at that time, was born with the purpose of making a survey of ex-members as a first step in the process of facing the issue. This program was not intended to reclaim these disfellowshipped members for the church, but was to serve as a method of looking at the congregation through the eyes of those who had been dropped from the fellowship of the church.

During this survey, 1,050 former members were visited throughout the South American Division. Perhaps the most important finding of the survey was that 90 percent of those disfellowshipped 
had never joined another denomination. It was found that most dropouts did not result because of theological disagreement, but rather because of some of the norms and practices of the daily 1ife. of the church members, which led to interpersonal conflicts, or to a temporary absence from the congregation resulting in eventual withdrawa1. An average of 87 percent of the backsliders who were interviewed still regarded themselves as Seventh-day Adventist Christians even after years of absence. The analysis of the results inpsired the second step which was launched during 1976, namely, the organization of study groups in local churches with the objective of analyzing different areas of congregational life in search of possible improvements. The final goal was to identify and eventually eliminate the possible source for dropouts.

A first experiment of the program was conducted at the central Seventh-day Adventist (SDA) church in Montevideo, Uruguay. It was later extended to the entire territory of the South American Division.

On-going refinement of the entire process was undertaken in connection with formal Doctor of Ministry degree program course work and in a field test in two Spanish-speaking congregations located in Dallas and Houston, Texas, during January and February, 1980. After this test, some conclusions have been drawn to make the program more practical. These conclusions are presented at the end of this project dissertation. 
Purpose and Objectives

Since 1966, the General Conference of Seventh-day Adventists has placed special emphasis upon the need for revival within the denomination. This appeal has been based on two specific concepts: (1) the need for a spiritual renewal, and (2) the elevation of evangelism as the primary task of the church.

The nature of this revival, the role human beings play in its achievement, and its relationship to evangelism, are not always clear. A study of the meaning of renewal, coupled with a practical, feasible approach to it, needs to be attempted if the church is going to enter into this experience. This project is an effort to make such an attempt.

As a possible tool to initiate the search for renewal, the project includes a program of self-assessment and goal setting aimed at an improvement of the quality of congregational life and climate in order to prepare the church to receive new members and to reduce the number of dropouts.

The study originally took place in the setting of Latin America, where the SDA church is experiencing a remarkable increase in membership. The South American Division incorporated 45,026 new members during 1978 and 50,174 during 1979. The figures for the Inter-American Division were 54,695 and 61,565 for the two years, respectively, making a total of 271,460 new members added in two years in the Latin American continent. The combined membership of the two Divisions at the end of 1979 exceeded the one million mark. The resultant rejoicing over new members, however, may well 
change to sadness should many of these individuals leave the church through the back door of apostasy. This study, therefore, is also intended to help prepare a local congregation to receive and integrate newcomers by fostering a spirit of effective nurture. The plan presented is deemed useful for preparing a local congregation for an evangelistic campaign, whether public or personal in nature.

\section{Limitations}

This program is limited to the analysis of the quality of congregational life and mutal relationship among members. Some aspects related to the structures of the administration of the church will not be examined unless they relate to or directly affect the life of the congregation under. study.

Due to the limitation of time, a long-term evaluation of the results of the field tests conducted in Texas has not been possible. Therefore, the analysis is limited only to the self-assessment and goal-setting stages. In the application of the program, however, a continuous evaluation is envisioned.

The field tests conducted in Texas may not fully reflect the situation other congregations face. According to past experience, however, it is believed that these congregations are generally typical of a Latin-American congregation.

\section{Overview of the Study}

This project dissertation is divided into seven chapters. In chapter II an attempt is made to analyze the nature of the church as a divine organism and a human organization. As a divine organism 
it is the body and the bride of Christ, but as a human organization it often takes the form of an earthly institution and, therefore, subject to the frailties of our broken human condition.

Chapter III deals with the necessity of renewal in the church if it is to recover its influence upon society and fulfill its mission. In this chapter current literature is reviewed with special attention being given to processes which might facilitate this experience.

A model of a self-assessment program for a local congregation is presented in chapter IV. The objective of the program is to discover areas in which improvement is indicated.

A pilot test of the self-assessment program conducted in two Spanish churches in the state of Texas (Dallas and Houston) is evaluated in chapter $\mathrm{V}$. Some clues are identified as to areas where changes or improvements are indicated.

After the self-assessment is accomplished, the goal-setting process begins. Therefore, chapter VI presents the results of the study groups formed for this purpose in Dallas and Houston. The value of the suggestions given by the study groups is also discussed.

\section{Definitions of Terms}

Apostasy. Apostasy is used to describe a total departure from the Seventh-day Adventist church, either by disciplinary measures taken by the church or by voluntary abandonment of the church by the member.

Backslider. Backsliding and apostasy are used synonomously in this paper. 
Church. Depending on the context, the church may be understood as the Christian church as a whole, a denomination, or a local congregation. When referring to the Seventh-day Adventist church it could mean any one of the organizational levels from the local congregation to the General Conference.

Dropout. The term dropout is similar in meaning to categories described above, and designates an obvious loss of interest in the church by one of its members. A dropout, therefore, is a member who leaves the church.

Dualism. When applied to the church, dualism means two different natures, the human and the divine. It is not used with a theological or philosophical meaning in this paper.

Environment. Environment is used in this project with two meanings. When speaking of the relationship between the church and its environment, the term means the outside world for which; and in which, the church is working. When speaking of the environment of the church, it denotes the climate existing within the congregation or the denomination.

General Conference. The central governing organization of the Seventh-day Adventist church is referred to as the General Conference.

Goal setting. The expression, goal setting, is used to identify the process by which the suggestions for improvement can be transformed into goals and the means for achieving them.

Inter-American Division. The geographical section of the General Conference of Seventh-day Adventists comprising Mexico, 
Central America, Colombia, Venezuela, the Guianas, and the Caribbean Islands, is called the Inter-American Division.

Latin America. That part of the Americas where Spanish and Portuguese are the commonly spoken languages is called Latin America.

Self-assessment. A process by means of which the congregation looks at itself, comparing present realities with the ideal to be reached, is self-assessment.

SDA. SDA is a commonly used abbreviated designation for Seventh-day Adventist.

South American Division. The geographical section of the General Conference of SDA comprising the eight countries of South America located south of the borders of Colombia, Venezuela, and the Guianas, is called the South American Division. 
CHAPTER II

THE DIMENSIONS OF THE CHURCH

The understanding of the nature of the church, its mission, and its relationship to the environment, is a key element in the success or failure of the work and witness of the church. The purpose of this chapter is to analyze the divine and human dimensions of the church and its relationship to the external world. A very important aspect of the latter is the process of accommodation to the environment that often occurs in religious organizations.

The church is an entity fundamentally different from any other institution. It was born with a particular mission related to the proclamation of the lordship of Jesus Christ, the Messiah of the Jews (Acts 2:36). The church was not to be a fortress isolated in self-concern, but was to fulfill a specific mission--the communication of the good news of salvation made possible by the Messiah. The inspiration and motivation for the fulfillment of such a mission came from heaven, while the actual performing of the task was entrusted to mankind.

There is in the church a divine and a human dimension. The divine dimension is not present in totally secular institutions or organizations. C. Norman Kraus establishes the differences between a society, a club, a sect or denomination, and a movement. He defines a society as "an organizationally defined association which 
forms on the basis of compatibility or agreed-upon regulations and goa1s." The same author adds one very important characteristic of a society: "It may be activity- or project-oriented and altruistic in its purposes, but it exists for the members, for accomplishing their purposes and for whatever other advantages may come with membership."1

A club is imilar to a society but is more oriented toward the self-fulfillment or pleasure of the group. The following definitions are given in an English dictionary:

[1] An association of persons meeting periodically (under certain regulations) at some house of entertainment for social intercourse.

[2] An association of persons interested in the promotion of some object.

[3] An association of persons formed mainly for social purposes, and having buildings for the exclusive use of the members, and always open to them as a place of resort. 2

While the church is essentially different from this, in reality it could resemble other entities and adopt similar forms while passing through the different stages of a metamorphosis studied and defined by Ernst Troeltsch. 3 Every religious institution--acording to his thesis--passes through a process of change which affects its type of organization, leadership, and authority. During this process there are some more or less defined stages. "An organization begins with a man, becomes a movement that

${ }^{I}$ C. Norman Kraus, The Community of the Spirit (Grand Rapids: William B. Eerdmans, 1974), p. 27n (emphasis supplied).

2 William Little, The Shorter Oxford English Dictionary (Oxford: Clarendon Press, 3rd ed.), s.v., "club."

${ }^{3}$ See Ernst Troeltsch, The Social Teachings of the Christian Churches (New York: Harper and Row, 1960), pp. 993-99. 
develops into a machine and eventually becomes a monument."1

During this process ${ }^{2}$ the church could adopt the form of a club, a society, or a religious club or society with objectives and purposes similar to the former--at least in the actual way of acting. When the divine dimension is lost and the activities are oriented toward the perpetuation of the institution in detriment to the performance of its divine spiritual mission, when the individual becomes less important than the institution, then the living organism has been transformed into an organization. Only the human dimension remains.

Therefore, the church in its divine conception is fundamentally different from any political, social, commercial, or any other sort of organization; it has a transcendent dimension which the others do not have. It has, however, the human dimension as we1l, because, in spite of being born of heavenly parents, it has its existence on earth. The church is made up of and led by human beings. How can this duality be understood?

Human and Divine

The nature of the church is a paradox. The two dimensions-the human and the divine--are sometimes mutually opposed. As a divine organism, the church is the body of Christ and His bride. It is a "chosen race, a royal priesthood, a holy nation, God's own

$1_{\text {World Vision International, "Dangers," Christian Leadership }}$ Letter, December 1977 , p. 1.

2 The nature of this process is studied further in this chapter. 
people" (1 Pet 2:9). But as a human institution it is sometimes Laodicean--"neither cold nor hot" (Rev 3:15) and even "wretched, pitiable, poor, blind, and naked" (v. 17).

Paul addresses his epistles to the church of Corinth, to "those sanctified in Christ, called to be saints" (1 Cor 1:1). At the same time he says, "But I, brethren, could not address you as spiritual men, but as men of the flesh, as babes in Christ" ( 1 Cor $3: 1)$. Then he becomes more specific: "It is actually reported that there is immorality among you, and of a kind that is not found even among pagans; ... and you are arrogant" (1 Cor 5:1-2).

As a divine institution, the church is perfect, but as a human organization, it is imperfect. The body sometimes is sick (Jer 8:22), and the bride gives her love to others rather than to the bridegroom (Isa $1: 21$; Ezek $23: 1-3$ ).

Trying to explain the dichotomy between the two aspects of the nature of the church, theologians have made some distinctions between a visible and an invisible church, a militant and a triumphant church, a transcendent and an immanent church, a mystical body and a manifested reality, a vertical and a horizontal church.

"The visible church consists of all who are enrolled as members . . whose names appear on the registers of churches," says Kuiper, while "the invisible church consists exlusively of those who by grace of the Holy Spirit have been born again." 1 It is easy to know who are of the visible church, but difficult to identify those

$1_{R}$. B. Kuiper, The G1orious Body of Christ (London: The Banner of Truth Trust, 1966), p. 26 . 
of the invisible. Kuiper concludes that "this aspect [the invisible] of the church is glorious indeed." 1 To that group are applied the words, "Ye were sometimes darkness, but now are ye light in the Lord" (Eph 5:8); they are "lively stones.. . built up [as] a spiritual house, a holy priesthood" ( 1 Pet 2:5); they constitute the body of Christ (Co1 $1: 18$ ).

When the church is called "militant" and "triumphant," the idea of an imperfect present and a perfect future is implied. Ellen White states: "Let everyone who is seeking to live a Christian life, remember that the church militant is not the church triumphant." ${ }^{2}$ When the idea of righteousness by faith is introduced into this picture, another dimension is added: the church on earth is not perfect with the absolute perfection of God, but is perfect because the sins of its members are forgiven and it is declared perfect by God, who already paid their debts through Christ. Due to the church members' profession of faith in the Savior, the church in giory will receive the total whiteness prophetically manifested in the book of Revelation. Now, it is declared righteous; then it will be made righteous.

The idea of a "mystical body" and a "manifested reality" is presented by Richards in the framework of the interrelationships between the people of God and Christ, the people of God and one another, and the church as a transforming community with the world

${ }^{1}$ Ibi.d., p. 27.

${ }^{8}$ Ellen G. White, Fundamentals of Christian Education (Nashville: Southern Publishing Assn., 1923), p. 179. 
to whom it ministers. 1 The church as a mystical body is the union of all believers with Christ, and as a manifested reality is the "local assembly of believers in a relationship of union with each other." ${ }^{2}$

The concepts of the vertical and horizontal dimensions of the church have been a source of discussion among different thinkers of Christian theology. The vertical dimension represents the relationship between men and God, the horizontal, the relationship between men and men. One represents the mystical aspect of the life of the church and the other its social concern and efforts for the well-being of the community.

Again, the two elements are present in the life of that divine-human organism. The cross, symbol of the Christian church, has two parts--one vertical, the other horizontal. In the church, both dimensions are interrelated.

The Church as a Divine Organism

Two metaphors used by the apostle Paul are the basis for the understanding of the divine nature of the church.

The Body of Christ

The figure of the church as the body of Christ is used in four epistles (Rom 12:4-5; 1 Cor 12:12-27; Col 1:18-19; Eph 1:22), stressing different dimensions of the nature of the church. In

ILawrence 0 . Richards, A New Face for the Church (Grand Rapids: Zondervan Publishing House, 1970), p. 76.

2 Ibid., p. 80. 
Ephesians, the expression "body of Christ" is used to represent the church as an organism, while the expression "members of his body" describes the saints (Eph $1: 22 ; 4: 4,12,15-16,25 ; 5: 23,30 ; 2: 15$; 3:6). Ephesians and Colossians use those terms with the focus-primarily, not exclusively--on the interrelationships between Christ and the church. 1

The expression "head of the church". applied to Christ does not mean just a position of honor, such as the head upon the body, but a relationship of rulership of the head; a source of life, protection, direction, leadership for the whole body. The body is not, in Paul's conception, an appendage to or an extension of the head, but a manifestation of the head's government and influence. In other words, the church as a body is a manifestation before the world of the ideas, ideals, principles, and plans of Jesus Christ the Head. To a church which is searching for renewal, some lessons are taught through this Pauline metaphor. The church cannot exist without a Iiving relationship with the Head, Jesus Christ. As the head in the human body conveys vital influences, vigor, and motion to every part of the body, so Christ is the Source of life, vigor, energy, and growth to the church. The church cannot live without a vital unity with the head; without it, the church is only a corpse. This interrelationship functions in a two-way process.

Meyer presents the idea of the two kinds of nerves that unite

${ }^{1}$ See Marcus Barth, The Broken Wa11: A Study of Ephesians (Chicago: The Judson Press, 1959), p. 115 . 
i. he head and the body as a symbol of that interrelationship: the eiferent and the afferent nerves. ${ }^{1}$ The efferent nerves carry volit. from the head to the extremities of the body, withdrawing the For from the thorn or compelling the hand to plunge into the flame. $\therefore$ is not an action of the foot or the hand, but a reaction through i impulses of the brain that are in the head.

Likewise, the individual Christian and the corporate body snould receive their impulses from Jesus Christ. When the church noters into the temptation of being transformed into a human enterrise, governing itself by well-elaborated policies, trusting in the roler of its budget, or the wisdom of its strategies, or in the in$\because$ 1ibility of its plans, then it should remember that its life, arity, and health are dependent upon its Head.

As a young swimmer lies paralyzed because of an accident in anch his spine was broken, and which in turn has broken the communicaAn between his body and brain, so the human-directed church is malyzed, in spite of its wise policies, good intentions, or its is rge budget. The paralyzed swimmer has a stomach and two lungs, i he cannot swim any more because the body no longer receives mes-

from the head.

The church, as a whole, must take its commands for suffering or warfare from no other lips than Christ's. Whatever course may be dictated by expediency, policy or human leadership, she dare not move until Christ gives the signal. But, if He bids her advanice, protest or suffer, she has no option but to obey. Though every voice that can reach her may be

\footnotetext{
$1_{F}$. B. Meyer, Ephesians, A Devotional Commentary (Grand vapids: Zondervan, 1953), p. 84.
} 
raised in expostulation and warning, she dare heed none but
this. 1

The afferent nerves are also important for the well-being of the body. They carry to the head the impression of what is happening to the body. Anything, good or bad, that happens to any part of the body is instantly communicated to the head. Pain and joy, failure or victory, the action of friends or enemies, everything is well known by the Head of the body. "Even the hairs of your head are all numbered" (Luke 12:7). "He who touches you, touches the apple of his eye" (Zech 2:8).

This communication cannot be cut off because the Head, Christ, cannot be separated from the body. The reaction of the body to the messages of the Head can be eliminated, but Christ is always in contact with what happens to His body.

This explains the importance given to prayer among the leaders and members of the apostolic church. When administrative problems were threatening to quench the prayer life of the twelve, they appointed "seven men of good repute, full of the spirit and of wisdom" to be in charge of secondary matters while they devoted themselves to prayer and preaching (Acts $6: 1-4$ ) in order to keep the body in contact with the Head. Both the miracles and the regular work of the church have to be performed "by nothing but . . prayer and fasting" (Mark 9:29) because, ultimately, the church is a living organism whose original message and power came from and must keep coming from God.

\section{${ }^{1}$ Ibid.}


The Bride

Ephesians 5:23-32 presents another metaphor stressing a different aspect of the divine nature of the church: purity, faithfulness. The sacred loyalty that must exist between husband and wife must be present in the relationship between the church and Christ. Again, Christ is presented as the head of the church, even as the husband is the head of the wife (v. 23). There is a sort of subjection of the church to the Head (v. 24); there is love from the "husband" to this wife, the church (v. 25). The church without Christ is a widow, a purely human institution.

Meyer compares the birth of the Christian church with the creation of Eve. As in Eden's story, it was not good for Christ to be alone. The Father sought a bride for his son from among the children of men." "He took the second Eve from the wounded side of the second man, as he lay asleep in the garden grove. Redeemed men compose that bride. Jesus loves as a first love and does everything to make her happy." ${ }^{2}$ The worth of Christ's loyalty is in the fact that "He loved the church and gave Himself up for her" (v. 25). In other words, He won the bride by the supreme sacrifice of Himself. The bride is His. When the bride is not loyal to and dependent upon her husband, she is an adulteress (Hos 1:2), or even a harlot (Rev 17; $19: 2)$.

Another dimension is added when the purpose of that sacrifice

${ }^{1}$ Ibid.; see also Charles R. Erdman, The Epistle of Paul to the Ephesians (Philadelphia: The Westminster Press, 1931), pp. 197-98.

2Meyer, pp. 90-91. 
is presented: the cleansing of a church, sanctified, "not having spot, or wrinkle, or any such thing; but that it should be holy and without blemish". (Eph 5:27). The purity of the church is not possible without unity. A club, a society, any other human enterprise could have ethical principles and morality; but only the church is purified by a divine element, because it alone is a divine organism.

The Church as a Human Organization

Not all is spiritual and divine in the life and work of the church, as not all in marriage is romance. In marriage, husband and wife are human. Moreover, they have many prosaic duties to perform. The same is true in the church.

The church is formed by all classes of believers, some really converted, and others who oniy profess "Lord, Lord" (Matt 7:21). Ellen White declares: "There are moral icebergs in the church, ${ }^{1}$ and "not one in twenty whose names are registered upon the church books are prepared to close their earthly history." 2

Paul speaks about "dangers . . from men who claim to be brothers in Christ but are not" (2 Cor 11:26, Living. Bible); the harm produced to him by Alexander, the coppersmith (2 Tim 4:14); his struggles with Peter (Ga1 2:11,12), etc. Such symptoms of the human dimensions of the church are found throughout the entire Bible, not excluding, obviously, the three and one-half years of the formation

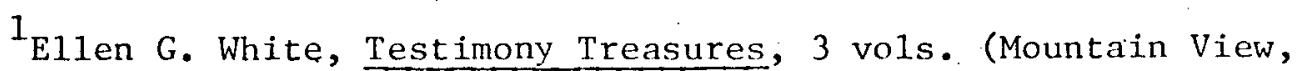
Calif.: Pacific Press Pub. Assn., 1949), 2:355.

${ }^{2}$ E1len G. White, Christian Service (Takoma Park, Washington, D.C.: Review and Herald Pub. Assn., 1947), p. 40. 
of the group of the twelve, when Judas and Peter, for example, showed so clearly that they were human beings.

There are some aspects of the life of the church in which God will not operate through miracles. As in any other organization, there will be policies and regulations, superiors and subordinates, receipts and expenditures, salaries, pensions, buildings, trave1, abundant material, and secular activities. ${ }^{1}$ This is normal. The existence of these activities is part of the life and work of the church. The problem lies in the proportion by which each area dominates the body. "The world of religion is part of the life of men on this earth and can become secularized as readily as any other world, despite the religious labels affixed to everything within it." 2

The problem, therefore, arises when trying to keep these secular aspects in their due proportions because growth will demand increase in material and human elements, sometimes to the detriment of the spiritual aspects; or the two elements could become independent of each other, not having the secular activities spiritually motivated.

This is probably the most serious reality the church has to face. Many individual congregations and corporate religious organizations have been transformed into monuments by secularization of the former movement that, having lost the spiritual power, preserves the

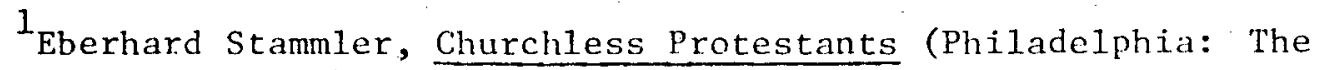
Westminster Press, 1964), p. 26 .

2 Daniel Jenkins, Beyond Religion (Philadelphia: The Westminster Press, 1962), p. 72 . 
political or material power, and in doing this has lost sight of its original goal.

The permanent struggle between the church and the environment, a decisive element in the understanding of apostasy and reviva1, has to be deeply studied in order to keep the church on the right track. The church has responsibilities toward God and toward the world. How can these be fulfilled?

\section{The Church and the World}

The relationship between the church and the world has been explained in a number of different ways. "Sometimes we contrast Church and world and sometimes we include one in the other," says McCabe. ${ }^{1}$ The Bible author who mentioned the term "world" the most often was probably John, and McCabe points out the "confusing" ideas presented by the fourth evangelist. "If you re-read St. John with an eye open for what he has to say about the world, the first general impression you"will get is of hostility tempered by confusion." 2 He then presents the following arguments:

1. The world and the Father are opposite concepts (1 John $2: 15-16):$

--Love the world, or love the Father

--What is in the world--1ust, pride--is not of the Father

--The world passes away; the one who obeys the Father abides forever

$1_{\text {Herbert McCabe, "The Church and the World," in The Meaning }}$ of the Church, ed. Donald Flanagan (Dublin, Ireland: Crili and Son, 1966), p. 55 . 
2. God so loved the world that He gave His only Son as the Saviour of the world (John $4: 13$ ):

--Christ came to overcome the world and to save it;

He has and has not come to judge the.world.

He concludes: "The whole thing is very puzzling--an exacerbated case of a love-hate relationship. . . We are investigating a mystery and ought not to expect easy solutions." ${ }^{1}$

Montgomery, in explaining the nature of the church as ecclesia, translates it as "that which has been called out from the world by God." He then adds an intriguing expression: "Here we have the first two characteristics of the church: radical separation and radical God-centeredness." 2

What is meant by "radical separation"? Is it the separation that characterizes hermits or anchorites? An analysis of John 17 clarifies the apparent confusion. The problem lies in the paradox that the world and the church are separate yet live together. This analysis can be shorn briefly as follows:

1. Jesus was not of the world (vv. 14, 16)

But He was sent to the world (v. 18)

He was in the world (v. 12)

He spoke in the world (v. 13)

He was leaving the world (v. 11)

2. The disciples were not of the world (vv. 14, 16)

They had been given to Jesus "out of the world" (v. 6)

${ }^{1}$ Ibid., pp. 56-57.

2 John Warwick Montgomery, Damned through the Church

(Minneapolis: Bethany Fellowship, Inc., 1970), p. 27. 
They should remain in the world (v. 15)

Jesus sent them into the world (v. 18)

The world hated them (v. 14)

In the world, but not contaminated by it (v. 15)

Figure 1 illustrates a common conception of the actual relationship between world and church.
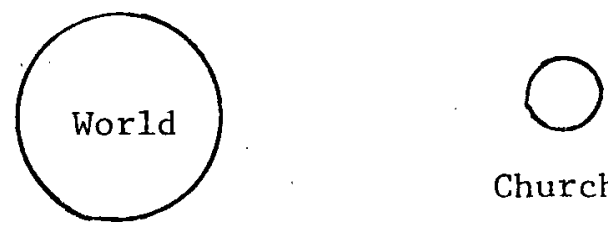

Church

Fig. 1. The relationship between the church and the world.

The church is an entity separated from the world by principle. To be in the church is to be out of the world. This attitude has been called "separationism," 1 and has been adopted through the centuries by hermits, anchorites, different kinds of monasticism, and in a more moderate form, by Anabaptists, Puritans, etc. Christ, however, prayed, "I do not pray that thou shouldst take them out of the world, but that thou shouldst keep them from the evil one" (John 14:15). The church cannot live physically outside of the world. Such a position is illustrated in figure 2, and may be contrasted with the relationship between the church and the world as depicted in figure 1. The former represents what is known as Synthesis, or

${ }^{1}$ In chapter 5 of Glenn H. Hinson, The Integrity of the Church (Nashville: Broadman Press, 1978), is an excellent study of five different positions aiout the relationship church/world: namely, Separationism, Syncretism, Synthesis, Dualism, and Conversionism. This section of the study is based on that chapter. 
Conversionism, and means an adaptation of the church to the environment in order to work for it. This is characterized by moderation and acceptance of the truth wherever it can be found, within or without the church. Of course, the church needs to adapt itself to the needs and characteristics of the world to which it has to minister, in order to avoid selling a procuct that is neither needed nor wanted by the environment, or its endeavors will result in failure. As Kelley points out, some churches not tuned in to realities are dying. 1 The problem arises when the price paid for adaptation is giving up principles which should not be changed or negotiated.

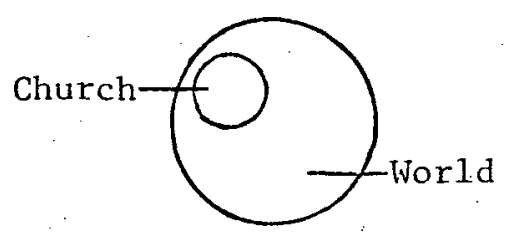

Fig. 2. The relationship between the church and the world.

What Hinson calls Conversionism ${ }^{2}$ is the other possible alternative. With this in mind it is easy to understand the apparent confusion of John in the gospel or his epistles. The church exists with a mission in the world. It has a message to share; namely, salvation from the power and consequences of evil. Both the church and the believer are inside the world, living, working, eating; however, in spite of being in the world, they are not of the world. "You are to influence them, not them influence you!" (Jer 15:19, Living Bible).

${ }^{1}$ See Dean M. Kelley, Why Conservative Churches are Growing (New York: Harper and Row, Pub., 1972).

2Hinson, p. 77. 
It is necessary again to go back to the reason for the existence of the church. The original purpose was not the formation of a superstructure to be a substitution for the structure of the world, an alternate choice. Rather, it exists to fulfill a mission inside the world. "One joined the new movement in order to be part of God's mission to the world, not to escape from it or to set up some island of security in it. "1 In other words, christians do not enter the church in order to find security, but to unite themselves with a program to transform and save the world.

Getz uses two terms, "separation" and "isolation," which are sometimes confused. The church has to be separated from the world, but it does not have to be isolated. "We are not to become a part of the world--living as the world lives--but neither are we to become isolated from the world. Others need to (they must) see in us what it means to be a disciple of Jesus Christ." 2

A very important point is whether the hate of the world toward the church is always directed to the divine organism or to the human organization. Again, the answer has to be twofold. There is an eternal enmity, a duality, between the two elements which was evidenced as early as Gen 3:15--an enmity between the seed of the serpent and the seed of the woman. This dualism is presented throughout the whole Bible:

$$
1_{\text {Kraus, }} \text {. } 27 \text {. }
$$

2 Gene A. Getz, Sharpening the Focus of the Church (Chicago: Moody Press, 1974), p. 233. 
Deut 30:19-20: Life and death, blessing and cursing

Josh 24:15: Yahweh or the pagan gods

Matt 7:13-29: Two options clearly illustrated

Matt 25:31-46: Final separation; two positions

John 3:6 Flesh, Spirit (Rom 6 and 8)

2 Cor 6:14-18: No partnership, no fellowship, no accord, nothing in common, no agreement

In the actual rejection of the church by the world, cosmic hate is not always present; rather, the opposition may be directed toward a human structure, a denomination, a corporation, and not against the holy body of Christ. Would it be possible to establish a distinction?

The church as a human organization suffers the same limitations as human beings suffer; it is imperfect, in permanent need of correction. This was the experience of the inconstant Israel and even of the Christian church, which in prophecy was accused of many sins (Rev 2:4, 14, 20; 3:15-20).

Caemmerer developed a study of the reasons for the "resistance of the world to the church," arguing that that kind of opposition is against what he calls a "pharisaical," "hypocritical," or "outworn" institution, situations produced by materiajism, ritualism, self-righteousness, and lovelessness in the life of the church. ${ }^{1}$ This conception is not a compliment to the church, but it sounds much like those of the prophets, in judging the church, or of Jesus in describing the so-called "people of God" of His time. Besides,

${ }^{1}$ Richard R. Caemmerer, The Church in the World (St. Iouis: Concordia Pub. House, 1949), pp. 26-39. 
Caemmerer refers to a rejected institution, not the body of Christ when faithfully fulfilling its mission.

The Process of Accommodation

It is difficult to make a clear difference between being in the world and not being of the world in the actual life of the church. History reveals clearly how the pressures of the environment and the process of growth eventually produce some changes in the church: the original fervor of the movement, the "first love" (Rev $2: 4)$ fades, and a compromise with the world occurs.

Based on the theories of Troeltsch and Weber, Teel presents: three areas in which the evolution is manifested during the process of the growth of the original movement:

1. Type of organization: from sect to church

2. Type of leadership: for prophet to priest

3. Type of authority: from charisma to bureaucracy ${ }^{1}$.

Snyder presents the typical case of a member of a local congregation who becomes tired of the institutional church, joins other members who feel the same way, and starts a movement of renewal, rejecting the structures of their former church. Very soon, however, a type of structure develops among them, perhaps better than that which they rejected in their mother church, but structure nonetheless. Snyder defends structures because life must have form; without form, life is sick and dies. "Structure is inevitable but not all church

${ }^{1}$ Charles Teel, Jr., "llow to Be a Movement, Not a Machine," Spectrum, Spring 1975 , p. 30 . 
structures are equally valid," Snyder affirms. ${ }^{1}$

There are two dangers with structures, however:

1. The structure enlarges beyond the mission which it is

designed to fulfill. Stammler describes the process in a graphic way way. The church has two levels, the upper story and the lower rooms. The upper story is the reception room, where the pure gospe1 is and the "theology of the cross" is preached. The lower room is the everyday reality of the church, and it is essentially different from the upper level. According to the structure, the movement and activity of the upper room section seem to be something secondary, comparable to a modest attic, as "modest and decorative as the opening and closing prayers used to begin and close some business meetings of the church." 2

There is, according to Stammler, a contradiction between goals and attitudes or expressions of the two sections. In the "upper room," self-surrender, discipleship, modesty, and humility is preached, while below, power and success is the valid criteria. Whereas the law of love and the power of faith and prayer have validity "above," the tactics and power of the organization reign "below." The human structure with the natural human egoism and pride is the reality "below," while renunciation of human power and worldly honor is the norm "above." "Above," the winning of souls, the finishing of the task of the church, are the goals; "below," the

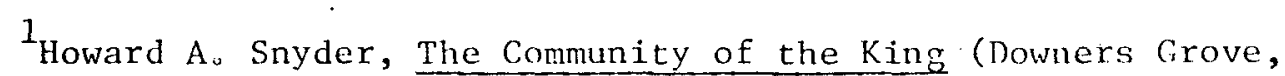
I11.: Inter-Varsity Press, Third Printing, 1978), pp, 137-38,

${ }^{2}$ St ammler, p。27. 
administration of a big complex is the primary burden. 1

The former movement has become, then, a well-established institution, a recognized entity. It is no longer called a sect but a church. Its financial structure has become solid; its institutions in the medical, educational, and welfare areas have become well known and respected. A better informed and educated ministry leads the work; specialists in the most varied areas are prepared.

This process is what Jenkins calls religion's "own form of secularization" through which the church "becomes conformed to this world which passes away," creating "a world of its own, which is neither the real world in which faith lives nor the mixed and confused world of everyday" but one which "might be called the 'Sunday' world, the world of the church and its fellowship." 2 The strong calls for a renewal of the church are directed to that kind of church, which is judged as nonsense because its way of behavior contradicts its profession of faith.

2. The new structure, we11 organized as an institution, becomes active although it works toward wrong goals or has adopted wrong objectives. During the 1976 Annual Council of the Seventh-day Adventist church, held in Washington, D.C., a document called "Evangelism and the Finishing of the Work" was approved. The main concern expressed in that document was precisely this: the present danger--due to the growth of the church--was failing to focus the activities of the church toward the right goal. The document states that the leaders of the SDA church "still contend that their vision

$$
1_{\text {Ibid. }}^{2} \text { Jenkins, p. } 71 .
$$


is unblurred and undimmed," but honesty will force them to recognize the struggle the church faces in this area, which is "not unlike the struggles of other great movements through history." 1

The danger seen in the church is to believe in "reaching the objective while doing many lesser things of a laudable nature that fall short of this goal," the proliferation of secondary activities, being "so busy doing the urgent that we have no time to do the important." The burden of the document is the setting of priorities to guide the church in her movement toward revival. The document clearly speaks about the "primacy and centrality of evangelism," 2 which can never be replaced by any other activity.

When experiencing the symptoms of decay, some churches try to survive by engaging themselves in more world-directed activities. Kelley suggests:

Some contend that the churches are declining because they are simply not relevant to the needs of the day. To become more relevant, it seems, they. should show a greater interest in social problems, engage in more vigorous programs of social action and welfare. ${ }^{3}$

Ecumenism, merging among congregations, is another solution often considered as a way of salvation from decay. What is important here is not how to cure the symptoms, but how to attack the roots of the illness. A secular organization cannot fill the spiritual needs of the people.

The causes for the obsolescence of religion have been

\footnotetext{
1"Annua1 Council of SDA, "Evangelism and Finishing Cod's Work," The Ministry, December 1976, pp. 3-10.

2 Ibid., pp. 3-7. 3 Kelley, p. 13.
} 
classified as external and internal. The first are present when the organization is providing something which is not needed any more, that has been replaced by a more modern equivalent, or for which there are more modern methods of production. The second is when the organization is unable to produce what is needed, or to produce it with the required quality. ${ }^{1}$

The failure of some churches is not necessarily due to changes in the environment (external causes), but may be due to the incapacity of a secularized organization, in spite of excellent machinery, to provide a spiritual product needed by the community. It is impossible to produce shoes with the equipment of an oil refinery.

In conclusion, a church is intended to have a product. In the process of institutional or organie growth it begins to produce something different and to produce it effectively. In spite of this new ability or capacity as a church, it will fail because its mission is different. The growth of a church should always be a function of the better fulfillment of its mission. If not, growth could be likened to the growth of a cancer. The original movement, influenced by the pressures of the external. world or by internal trends, becomes an institution, a monument, probably with clear objectives or even a welldefined theology, but without power. It is now like a strong locomotive with all its wheels, spigots, and water, but without fire to transform the load into energy. Nothing in the church is worthwhile without the original fire.

$$
1_{\text {Tbid. }} \text {, pP. 17-20. }
$$


An Analysis of the Process of Accommodation

The process of transformation of a sect or movement into an established denomination or church has been carefully studied. It follows a more or less standard pattern which could be summarized thus: the original fervor of the movement or sect fades and compromises with the outside world occur. ${ }^{1}$

There are different viewpoints, however, between the religious and the sociological understanding of the meaning of the words used and the steps of the process. The word "sect" as sociologists understand $i t$, is not a reference to a heretical and sinfully divisive group in contrast with a wel1-respected "church," the upholder of the true faith and moral guardian of all the people, as it is understood in the religious vocabulary. For Troeltsch and Weber the sect is merely a movement of religious dissent, while a church an organization which, emphasizing sacrament and creed, strives to be coextensive with society. ${ }^{2}$ Richard $H$. Niebuhr an American theologian, sees the need of an intermediate type of organism between the two proposed by the European sociologists, and so adds a third: the denomination. ${ }^{3}$ Finally, a fourth group was added, and the stages can be conceived as follows:

1. The sect. A group that considers itself the sole true religion and; seeking to preserve its spiritual purity by remaining apart from the world, exercises close control over its membership.

${ }^{1}$ John Wilson, Religion in American Society (Englewood Cliffs, N.J.: Prentice-Hall, Inc., 1.978), P. 138.

2 see Wilson, Ibid.

3 Richard Fi. Niehuhr, The Social Sources of Denominationalism (New York: Meridian Books, 1.957), p. 
2. The established sect. A group that is willing to tolerate the truth claims of other religious groups, but is nevertheless exclusive in its membership and remains aloof from the world except for the purpose of spreading its message.

3. The denomination. An association that tolerates the truth claims of other religious groups and has liberal membership requirements.

4. The church. A body that claims a monopoly on the truth, but has a broad, all-inclusive definition of membership. ${ }^{1}$

During the process of accommodation to the world and experiencing the stages of growth, the spiritually oriented organism becomes a more or less secularized organization. Wilson says, "No matter with what fervor sectarians begin their protest against the world and with what dtermination they set themselves apart from it, they gradually relent and learn to live with it." 2

This process can be seen in almost every religious movement. Some sects do not survive, however, and disappear. Others seem to defy the rule and retain their distinctive characteristics. History tells us of the reality of the process in the majority of the religious movements.

Wilson presents the case of the Methodist church. Methodism was born out of Wesley's concern about the spiritual poverty of the Church of England and its complacent support of the social and political corruptions of its time. The original followers of the leader were simple people, worshipping in the open fields. Their interest was first to revive the spiritual life of the people.

Growth brought changes, however. The more or less organized

${ }^{1}$ See Roland Robertson, The Sociological Interpretations of Religion (Oxford: Basil Blackwell, 1970), p. 123, quoted by Wilson, p. 138 .

${ }^{2}$ Wilson, p. 140 . 
movement began to search for respectability. The new trends, as presented by Currie, could be applied to almost any other movement-Lutherans, Baptists, Quakers, and not excluding the Seventh-day Adventists.

They demanded better chapels; abandonment of biblical and doctrinal crudities; nice singing; "a good time"; modest pleasures; and a cheerful, happy, unambitious society. - . . Rising prosperity had weakened denomination commit-

The new goals were reached. The poor, rejected followers of Wesley, contemptuously called "Methodists," were transformed into a respected denomination of the middle-cjass society during a period of about a hundred years.

There is a very positive explanation of this phenomenon, which in the end has a negative effect upon the movement. The first followers are contestants of an establishment. Normally they are from the lower class, without higher education and social position. They are eager to face opposition. The new ideals given by that renewing experience will lead them into a better fulfillment of their jobs, to more opportunities for education, and a general desire for improvement. As a result of this new philosophy of life, they will be upgraded in society. It is at that moment, perhaps, that the original problems or issues faced by the founders, change. The new generation does not understand these problems and issues because it is so far removed. There is a loss of the conviction of their

${ }^{1}$ Robert Currie, Methodism Divided: A Study in the Sociology of Ecumenicalism (London: Faber and Faber, 1968), p. 140 . 
reason for existence, and a relaxation of the original standards. 1

"A steady job, a more stable family life, a wider circle of friends, greater political freedom, will change the priorities of members from challenge to comfort, from change to stability, from being different to being normal." 2

This process of accommodation is reflected in several attitudes of the movement, mainly in the admission standards and the meaning of membership, its relationship with the surrounding world, and the shift of organizational priorities。 ${ }^{3}$

1. The second generation belongs to the organization more by heredity than by personal choice. ${ }^{4}$ There is a difference between the original followers of Wesley, who had to face ridicule and even persecution, and the present generation of Methodists brought to the church from birth, who have never had to face a real crucial decision with the danger of persecution or ridicule. The name Methodist here could be replaced by Lutherans, Seventh-day Adventists, Disciples of Christ, or any presently respected denomination.

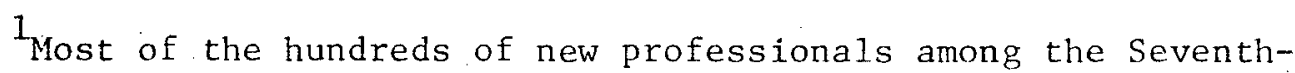
day Adventist members in South America are not new converts but are the children of a poorer generation, who, with the new doctrines grasped new ideas which led them to the universities, to degrees and a new status in society. Sociologists say that among the highly educated second generation, the original intensity of the message is somewhat dimmed. Two or three more generations and the pjcture of what relates to the evangelistic thrust, the fidelity to some of the standards of daily living and even the acceptance of some original doctrines could be changed.

$$
{ }^{2} \text { Wilson, p. 141. 3Ibid., pp. 144-1.46. }
$$

${ }^{4}$ In a survey conducted in the Spanish church of Dallas, Texas, in January 1980 , it was found that 64 percent of the respondents came to the church through their families, 17 percent through friends, 12 percent through evangelistic campaigns, 2.5 percent through publications, and less than 1 percent through the schools. In Houston the 
2. Membership in the denomination or the church is less rigorous than in the movement or sect. Religious norms are sometimes subordinated to the secular norms, and its agenda is frequently dictated by the external world. The reasons for attending church are shifted from the purely spiritual and transcendent interests to more social ceremonies.

3. The process of accommodation is seen in a third change: the attitude towards other similar organisms. The original sense of mission, clearly identified, gives to that movement an urgency in the fulfillment of its purpose. It considers itself as the only representative of the truth. Therefore, its campaigns do not exclude other religious bodies. When a certain degree of respectability is achieved, a new attitude of coexistence and cooperation with others is born.

The same phenomenon occurs in relationships with the community. The sect or movement has more clearly defined boundaries with the external world. The denomination or church is more friendly toward a closer identification with society. The boundaries are gradually eroded.

4. In the administrative structure a gradual increase in the number of professional leaders is seen, while the elements previously considered as the pillars of the institution receive less and less attention. A study of the categories of employed personnel in any growing religious movement shows a proportionately larger number of

figures were: family, 57 percent; friends, 25 percent; publications, 4. percent; schools, 2.5 percent; and less than 1 percent by evangelistic campaigns. 
pastors, preachers, and evangelists than administrators and departmental directors in the stage of sect. Gradually, however, specialization is required and the technical specialists begin to exert a broader influence in the whole institution. As their preparation is often received in secular institutions, with an approach different from that of the seminaries, their sense of priorities and even their sense of mission is also different.

In almost every religious organization there exists a sort of tension between the administrators and the personnel in the "lower ranks." As the process sect-to-church evolves, the relationships between the "top" and the "bottom" tend to worsen. 1

\section{Practical Consequences of This Accommodation}

When there is a dichotomy between the "ideal" and the "actual" life of the congregation, between its profession of faith and its actual behavior, the spiritual impact it is able to make upon the environment is diminished and a credibility gap is created. Raines says that this is the process of "domestication" of the church. "It is relatively easy to maintain the church busily occupied in cultivating her own garden. The world has pulled the teeth of the church and no longer listens to her enfeebled message. $" 2$

Another direct consequence of accommodation is the incidence

${ }^{1}$ For a very interesting study on this phenomenon, see Gerald J. Jud, Edgard W. Mills, and G. W. Burch, Ex Pastors. (Philadelphia: Pilgrim Press, 1970), pp. 23-30.

2 Robert Raines, New Life in the Church (New York: llarper and Row, 1961), p. 17. 
of dropouts. The people lose their admiration and love for the church when it is not different from the environment and when it ceases to be the source of inspiration.

The church is a very special kind of organization. It has a divine origin and message, but an earthly life. It has to transform its environment while being a part of it, yet without being negatively affected.

The influence of the environment is strong, however, and the danger of a process of accommodation always exists. This process could affect the understanding the church has of its own nature and mission and, accordingly, its pattern of growth or decline. When dropouts or decline occur, the church might study its own situation, searching for potential causes, beginning a campaign to eliminate them. 
RENEWAL AS A REMEDY FOR THE PROBLEM OF DROPOUTS

The purpose of this chapter is to examine the possible causes for dropouts from church membership and to suggest the importance of renewal as a valuable remedy. The special situation of the Seventh-day Adventist church will be briefly surveyed before presenting a review of different definitions of renewal and suggesting possible effects of the change of the internal climate of the congregation upon evangelism and nurture.

\section{Introduction}

The membership decline in some of the traditional churches in North America and in other areas of the world is a well-known phenomenon first observable in the late 1960s. Literature on the issue stresses three special areas where decline is evident: (1) confidence in the organized church, (2) church attendance, and (3) church membership. Of special importance is the study of probable causes for dropouts. As the topic has been extensively studied and the literature is abundant, it will not be analyzed here. ${ }^{1}$

${ }^{1}$ See Kelley, Why Conservative Churches are Growing; Montgomery, Damned through the Church; Sidney B. Parker, The Problem of Church Dropout (New York: Vantage Press, 1971); James L. Christensen, How to Increase Church Attendance. (Westwood, N.J.: Flemming H. Revel1 Co., 1961); Car1 S. Dudley, Where Have Al1 Our People Gone? (New York: The Pilgrim Press, 1979); and Roger L. Dudley, Why Teenagers Reject Religion (Washington, D.C.: Review and Herald Pub. Assn., 1978). 
Because this project is directed especially to the SDA situation, some statistical information and studies pertinent to this church will be noted.

The SDA Church and Dropouts

The problem of dropouts has been of real concern to the SDA church for decades. Table 1 shows the figures for the dropouts during the period 1976-78 in North America and table 2 for the world field.

TABLE 1

ACCESSIONS AND DROPOUTS IN THE SDA CHURCH IN NORTH AMERICA, 1976-78

\begin{tabular}{l|c|cc}
\hline \multirow{2}{*}{ Year } & $\begin{array}{c}\text { Baptism/ } \\
\text { Profession of Faith }\end{array}$ & Deaths & Apostasy/Missing \\
\hline \multirow{2}{*}{1976} & 32,232 & 5073 & 12,337 \\
1977 & 32,785 & 5073 & 13,563 \\
1978 & 30,422 & 4996 & 12,589 \\
\cline { 2 - 4 } & 95,439 & 15,142 & 38,489 \\
\hline
\end{tabular}

Source: Statistical Report of the General Conference of SDA, 1978.

These tables include only the members who have been already disassociated and do not take into account those who are on the records but who are missing, not attending at any time or attending only occasionally.

Some studies have been conducted seeking. to understand the 
reasons for these losses, but there is no agreement as yet on the findings.

TABLE 2

ACCESSIONS $\Lambda$ ND DROPOUTS IN THE SDA CHURCH IN THE WORLD FIELD, 1976-78

\begin{tabular}{l|cc}
\hline \multirow{2}{*}{ Year } & $\begin{array}{c}\text { Baptism/ } \\
\text { Profession of Faith }\end{array}$ & Apostasy/Missing \\
\hline 1976 & 235,169 & 72,746 \\
1977 & 243,735 & 80,526 \\
1978 & 250,608 & 65,360 \\
\hline & 729,512 & 218,632 \\
\hline
\end{tabular}

Source: Statistical Report of the General Conference of SDA, 1978.

James H. Smuts conducted a study in 1950 in which he suggests five areas of responsibility for membership losses:

1. Responsibility placed upon the church

2. Responsibility placed upon the individual

3. Social conditions

4. Educational backgrounds

5. Economic reasons

His final conclusion is that apostasies among SDA members are caused by "evangelistic shortcomings; pastoral failings; lack of true conversion; and economic conditions."

${ }^{1}$ James H. Smuts, "An Examination of the Reasons Leading Individuals to Apostatize" (M.A. thesis, The Seventh-day Adventist Theological Seminary, Washington, D.C., 1951), p. 51. 
Nielsen, in his survey, enumerated one hundred possible causes for apostasies. The study was conducted among former members (FM), pastors (AP), leaders (DL), and writers (DW). The most important factors listed are those presented in table 3.

Ila Zbaraschuk conducted a study to discover the problem of losses among SDA youth. He interviewed "academy kids, high school dropouts, a navy returnee, college students and college dropouts; as well as professionals, three youth pastors, some deans and a social worker." ${ }^{1}$ According to the opinions expressed, about 50 percent of SDA young people eventually leave the church, ${ }^{2}$ although some come back at a later tine either to remain or to stay for a short period. ${ }^{3}$ Some of the reasons given by those. interviewed were: (1) a sense of guilt for non-conformity with healthful living standards; (2) "nonessentials" elevated to importance by some adults (also called "misplaced emphasis"): (3) boring services; (4) poor quality of preaching of "sermons that sound like re-runs"; and (5) lack of pastoral assistance due to the transformation of the minister into a businessman. An interesting fact borne out also by other surveys, is that "no one person mentioned doctrine as a reason for leaving." 4

In the study conducted by the author in South America during

${ }^{1}$ Ila Zbaraschuk, "Why Young People Leave the Church," Insight, September 11,1975, p. 11 .

${ }^{2}$ Ibid., p. 14 .

3 The estimate varies from 40 to 50 percent of those who once left the church. Ila Zbaraschuk, "Why Some Come Back," Insight, September 25,1973, p. 16.

${ }^{4}$ Ibid., pp. 12-14. 
TABLE 3

A COMPARISON OF "HIGHEST RANKINE FACTORS 'CONTRIBUTING TO DISASSOCIATION FROM THE CHURCH AS EXPRESSED IN

PERCENTAGE BY FORMER MEMBERS (FM), ADVENTIIST

PASTORS (AP), DENOMINATIONAL LEADERS (DL), AND WRITERS (DW)

\begin{tabular}{|c|c|c|c|c|c|}
\hline & Reason & FM & $\mathrm{AP}$ & DL & DW \\
\hline 1. & Can't uphold church standards & 51.7 & 11.1 & 12.4 & 6.7 \\
\hline $2:$ & Stopped attending church & 50.3 & .9 & & 5.3 \\
\hline 3. & Lost interest & 44.3 & & & \\
\hline 4. & Drifted out & 33.6 & & 6.2 & 12.0 \\
\hline 5 . & Became lukewarm & 32.9 & 2.2 & 15.6 & 1.3 \\
\hline 6. & Stopped reading Bible & 28.2 & 20.4 & & 1.3 \\
\hline 7. & Working on Sabbath & 26.8 & 4.4 & & 6.7 \\
\hline 8. & Church is too condemning & 26.8 & & & 1.3 \\
\hline 9. & Premature baptism & 26.2 & 8.9 & 15.6 & 17.3 \\
\hline 10 . & Gain nothing from church & 23.5 & 22.2 & 9.3 & 11.3 \\
\hline 11. & Neglected praying & 23.5 & 20.4 & & 1.3 \\
\hline 12. & Hurt feelings & 22.8 & 18.1 & & \\
\hline 13. & Never converted & 22.8 & 33.3 & & 16.0 \\
\hline 14. & Smoking & 22.1 & 2.2 & & \\
\hline 15. & No close friends in church & 21.5 & & & \\
\hline 16. & Church neglects spiritual & & & & \\
\hline & development of members & 21.5 & 13.3 & 12.5 & 12.0 \\
\hline 17. & Members cold and indifferent & 21.5 & $4: 4$ & 12.5 & 9.3 \\
\hline 18 . & Married to non-Adventist & 19.5 & 1.8 & 8.9 & 1.3 \\
\hline 19. & Church too strict & 18.8 & & & \\
\hline 20 . & Church members have double standards & 18.1 & & & \\
\hline 21 . & Wanted to go to movies & 18.1 & & & \\
\hline 22 . & Stopped reading SDA literature & 18.1 & & 9.3 & 10.6 \\
\hline 23. & Family problems & 17.4 & & & 1.3 \\
\hline 24 . & Leaders press too much for money & 17.4 & 8.9 & & \\
\hline 25. & Never was a genuine Adventist & 16.8 & & & \\
\hline 26. & Sermons uninteresting & 16.8 & & & \\
\hline 27. & Pastors too critical & 16.8 & & & 9.3 \\
\hline 28 . & Disagree with church standards & 16.8 & & & \\
\hline 29 . & Using alcohol & 14.8 & 2.2 & & \\
\hline 30 . & Followed example of spouse & 14.8 & & & \\
\hline 31. & Church exalts E. G. White over Bible & 14.1 & & & \\
\hline 32 . & Wanted to go dancing & 14.1 & & & \\
\hline 33 . & Pastors indifferent & 14.1 & 8.9 & 31.2 & 10.3 \\
\hline 34 . & Church discriminating & 14.1 & & & \\
\hline 35 . & Church too conservative & 13.4 & & & \\
\hline 36 . & Members superficial & 13.4 & & & \\
\hline
\end{tabular}


TABLE 3--Continued

\begin{tabular}{lllrrr}
\hline Reason & FM & AP & DL & DW \\
\hline 37. Social disparity & 12.8 & 6.7 & 3.1 & \\
38. Church inconsistent & 12.8 & & & 1.3 \\
39. Divorce and separation & 12.1 & 4.4 & 28.1 & \\
40. Church is boring & 12.1 & & 6.2 & \\
\hline
\end{tabular}

Source: Louis Ch. Nielsen, "Disassociation: An Investigation into the Contributing Factors of Backsliding and Separation from the SDA Church in Michigan" (D. Min. Project, Andrews University, 1977), p. 288.

1973, the results are quite similar, with some variations between countries or geographical areas. Table 4 presents some of these results. 1

In spite of many similarities in the studies, there are also dissimilarities. A very important question has to be asked at this point: Are these reasons the real ones, or are they symptoms of a different disease? There are two possibilities here: (1) that the reasons given were just excuses or "outs" to justify a different situation, or (-2) that the reasons were real but only symptoms with a different root.

The next question to ask would be: Is there an answer to these excuses, symptons, or roots of the problem? All the reasons given could be synthesized into problem areas: problems with the

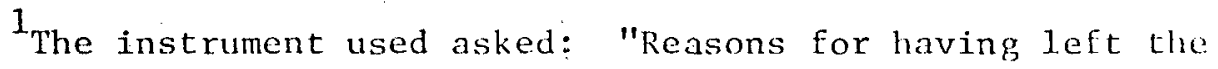
church," without giving a list of possibilities to mark. The answers were classified by items according to incidence. 
TABLE 4

CAUSES FOR DISASSOCIATION GIVEN BY BACKSLIDERS IN DIFFERENT COUNTRIES OF SOUTH AMERICA

\begin{tabular}{|c|c|c|c|c|c|}
\hline Reasons given & Argentina & Brazil & Chile & Inca Union ${ }^{a}$ & Uruguay \\
\hline 1. Sabbath observance & 31.0 & 20.5 & 16.0 & 20.6 & 35.3 \\
\hline 2. Adultery & 7.0 & 5.1 & 8.0 & 8.8 & 5.2 \\
\hline 3. Indifference & 6.8 & & 8.0 & 2.9 & \\
\hline 4. Eamily problems $b$ & 22.0 & 11.5 & 20.0 & 20.5 & 26.3 \\
\hline 5. Involvement in politics & & & & & 6.1 \\
\hline 6. Lack of care from the church & 5.5 & & 10.0 & 14.7 & 5.2 \\
\hline 7. Hypocrisy in the church & 1.3 & 2.5 & 8.0 & & 11.8 \\
\hline 8. Lack of preparation for baptism & 5.5 & 6.4 & 10.0 & 14.7 & 6.5 \\
\hline 9. Injustices in the church & 2.7 & & & & \\
\hline 10. Human relations in the church $^{c}$ & 15.0 & & 24.0 & 9.6 & 5.2 \\
\hline
\end{tabular}

ancludes Peru, Bolivia, and Ecuador.

b Includes marriage with non-Adventists, divorce, persecution by members of the family, etc.

c Includes interpersonal conflicts, conflicts with leaders, etc.

Note: Items 1-5: The responsibility is with the individual. Items 6-10: The responsibility is with the church. 
church and problems with the individual. Ultimately, however, the former could be identified with the latter in a sense. If the church were a source of real spiritual strength, a door to heaven, worshippers would receive the necessary power to face their own limitations and problems. Of course, this is an oversimplification. However, the church should search for a way to dininish the intensity of the problems, and one of the ways that could be utilized would be to facilitate a renewal experience.

\section{What is Renewal}

Due to the increase of dropouts and of a growing uneasiness because of lack of fruits among local congregations as well as in denominations, the desire for a renewal experience is general among churches. However, there is a large diversity of concepts about the nature of renewal as well as in the solutions proposed. A summary of some of these is presented below.

Different words have been used to refer to the renewal experience, such as revival, reformation, revitalization, renaissance, and renewal.

Tippett sees revival as the cure for the spiritual needs of the church, and revitalization as the cure for the organic needs, the former being the work of the Holy Spirit, and the latter the result of the operation of a human program, or a renewal of the structure. ${ }^{1}$ Engel and Norton see a difference between renewa1 and what

\footnotetext{
${ }^{1}$ Allan R. Tippett, Church Growth and the Word of Cod (Grand Rapids: Eerdmans Pub. Co., 1970), pp. 67-68.
} 
they call renaissance. Renewal "implies going back to an earlier and better day," while renaissance is to "look forward to what is yet to be discovered." 1 The important issue here is whether the model for today's church is the apostolic period or a totally new model. which better fits the needs of the contemporary world. McGavran stresses the common misunderstanding of what the experience means to different Christians. "To the ignorant it signifies an unfortunate trait of frontier life and lower class denominations," or "an emotional orgy stirred up by a professional which creates an illusion of spiritual well-being and leaves congregations much as they were before," while for others it "means primarily purifying and vitalizing the existent church." 2

Pinson points out the different emphases given by various streams of renewal.

One stresses the role of the laity . . ; others point up key pietistic themes such as prayer, meditation, and Bible study. Many spring to attention when the Spirit-filled life is mentioned. Others come alive to evangelism or ministry or Christian concern. 3

Worley listed six means used to achieve renewal, all of them, according to the author, lacking the vision of the congregation as a whole and dealing only with separate aspects of its life. ${ }^{4}$

${ }^{1}$ James F. Engel and H. Wilbert Norton, What's Gone Wrong with the Harvest (Grand Rapids: Zondervan Pub. House, 19.75), p. 144.

2 Donald McGavran, Understanding Church Growth (Grand Rapids: Eerdmans Pub. Co., 1970), p. 163 .

3 William Pinsori, Jr., The Total Dimension of Renewal, quoted in George Worre11, ed., Resources for Renewal (Nashville: Broadman Press, 1975), pp. 53, 54 .

${ }^{4}$ The six strategies are discussed by Robert C. Worley, Dry Bones 
What is to be changed through renewal is another disputed issue. Is the church what needs to be changed, or the perceptions or attitudes toward its reality? According to Jacobsen, what is needed is a change of attitudes, "not new programs but new people." 1 Others are more radical in their solutions. Some believe that the structures of the church are obsolete and should be rejected. Such is the case with Cosby's Church of the Savior in Washington, D.C., 2 and a new breed of home churches, Christian effeehouses, shopping and storefront churches. ${ }^{3}$ The theology of liberation and the charismatic movement are two contrasting additional options. One sees renewal as struggle for social justice and the other as the reception of the gifts of the Spirit, especially tongues.

A thesis of this study is that an experience of renewal must affect individuals as well as the corporate church; it must change perceptions of the individual as well as norms and practices of the congregation; it must foster love to God and love to one another; it is not a utilitarian experience but one directed to evangelism.

The final product of a renewed congregation will not necessarily be a mystical experience but a new life style which in turn makes the Christian faith appealing to others. As a result of this

Breathe (Chicago: McCormick Theological Seminary, 1978), pp. 7-15.

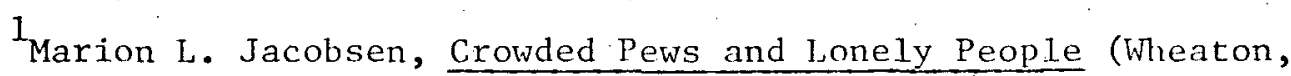
I11.: Tyndale House, 1975), p. 59.

${ }^{2}$ See Elizabeth o'Connor, Journey Inward, Journey Outward

(New York: Harper and Row Pub., 1968); Gordon Cosby, Handbook For Mission Groups (Waco: Word Books, 1975).

${ }^{3}$ See Rudger Reitz, The Church in Experiment (Nashville: Abingdon Press, 1969), pp. 37-53. 
revitalization people will be attracted to the church, producing an increase of accessions, and a diminishing number of dropouts. Renewal is the secret of multi-dimensional growth. ${ }^{1}$

An important aspect of the subject of church renewal involves the question of who is responsible for its realization. This study assumes that there is a primary and a secondary initiative, the former belonging to God and the latter to man. God's initiative in this matter is always available; man's initiative has to be cultivated. God's power operates in both the abandoned field and the beautiful garden. There is fruitage, however, only when the farmer plows the ground, sows the seed, and cares for the whole process. God does not make orange trees grow everywhere, but only where men have planted orange trees.

God's power is always operating in the church. One church, however, may experience it while a neighboring one is by-passed. What the latter lacks may be the human initiative that prepares the way for God's Holy Spirit to operate. The fault is not God's, but men's.

The problem of dropouts is real and is produced by some known and some unknown factors. Renewal of the life of the congregation is suggested here as an important solution to the problem. In

${ }^{1}$ See Getz, pp. 29-30, 206; George Hunter ITI, The Contagious Congregation (Nashville: Nbingdon Press, 1979), pp. $108-$ 172; Donald Mccarran and W. C. Aru, Ten steps for Church Growth (New York: Harper, 1977) p. 76; LeRoy Lawson and Tetsunio Yamamori, Church Growth: Everybody's Business (Cincinnati: Standard Publishing, 1975), p. 74 . 
spite of the discrepancies between Christian leaders about the meaning of the expected experience, the power of God is ready to operate when men prepare themselves for that operation. Part of this preparation is the awareness of the real situation of the church, aimed at improvement. This is the subject of the next chapter. 
CHAPTER IV

THE SELF-ASSESSMENT PROGRAM

The process of accommodation to the world which was studied in chapter II might affect the impact made by the church upon the community and its consequent growth or decline. Therefore, renewal is a necessary experience.

It is my conviction that the actual situation of the congregation should be evaluated as a first step toward renewal. The awareness of needs would presumably contribute to changes where deemed necessary. Those changes could strengthen the life of the congregation, affecting its impact upon unbelievers and contributing especially to the confirmation of those who are already members.

This chapter proposes a practical program of self-assessment for a congregation, aimed at renewal for successful evangelism and effective nurture.

\section{Objectives of the Process}

There might be some reasons for the troubles of the church. Jacobsen, speaking about the need for a change of attitudes toward things, says, "If people dislike me, it will be good to ask: Why is it? Being sincere with myself, probably I will discover things 
others see and I don't." 1 This is a good way to start the process toward renewal in the church. At the beginning of one of his books, Brown asks: "Where do we start, in finding out what is amiss in the church today?" His answer is: "We will not start with the Holy Scriptures or Calvin. - . We will start not by proclaiming but by listening. - . Before we offer answers, we need to know the questions." ${ }^{2}$ James F. White says: "Any important step forward must begin with a backward look so as to gain self-knowledge." 3

This process of self-knowledge and self-understanding has been well defined by Kurtz, who says it is

A process through which persons and organizations look at themselves, where they are, and where they would like to be. In congregational self-assessment a process is developed whereby those within the congregation collect data, interpret the meaning and plan their own course of action. 4

This self-assessment might be directed toward feelings (How does one fee1?), perceptions (What does one see?), knowledge (What does one know?), or even be an evaluation (What judgment does one make about how one feels, what ore sees, and what one knows?). According to the style used, it might be a "descriptive" or a "prescriptive" assessment, depending on whether its objective is to measure the actual life of the congregation only, or if it is an evaluation of the

${ }^{1}$ Jacobsen, p. 59 .

2 Robert M. Brown, Frontiers for the Church Today (New York: Oxford University Press, 1973), p. 3 .

3 James F. White, Christian Worship in Transition (Nashville: Abingdon, 1976), p. 62:

${ }^{4}$ Arnold Kurtz, Leadership for Church Organizations (Berrien Springs, Mich.: Andrews University, 1979), p. 55. 
present reality of the life and thought of the church compared with the idea1. 1

Therefore, the objective of the process is to discover the truth and face it. It is easy to say, "I'm OK, you 're OK," in dealing with the life of the church. But it is not healthy. The opposite attitude is cheap criticism behind doors. This is negative and destructive. It can be transformed into evaluation and be a positive tool for change and renewal. "The major standard for a healthy organizational climate," says Anderson, "is whether or not the system rewards or punishes, supports or denies the actual facts of its ongoing 1ife." He then adds, "Most organizations punish the truth."2 The church leaders' understanding of the true reality of the church will inspire the search for solutions and will help to avoid the sense of frustration of an organization that is trying to arrive somewhere without knowing its destination. It is possible to have in the church total unity of forces pushing together but in the wrong direction. Only a sincere self-assessment will help to avoid this. "Changes should never even be contemplated without a thorough assessment of the current situation and determination of the reasons for the problem that exists." 3

Several questions should be asked by both leaders and laity to discover that truth:

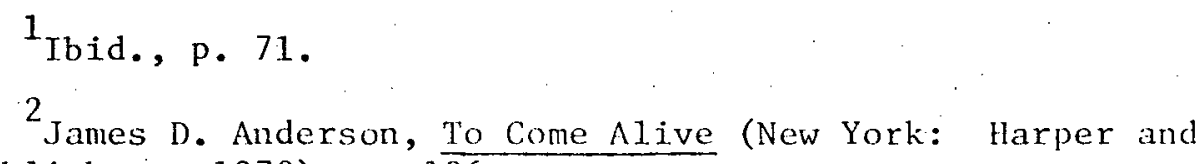
Row, Publishers, 1973), p. 106.

${ }^{3}$ Engel and Norton, p. 145. 
1. Who are we? This denands an understanding of the nature and the function of the mission of the church.

2. Where are we supposed to go?. This requires a knowledge of the objectives of the church as an organization.

3. Where are we going now? Leaders must be aware of the present reality compared with the ideal.

4. How can we move from here to there? This demands an analysis of the possible means to give intentionality and clear goals to activities of the congregation.

5. What are we going to find in the way? It is necessary to identify possible obstacles that may have to be faced and overcome during the process of achieving the goals.

6. How can we know if we are going in the right direction? It is essential to make permanent evaluation along the way, comparing goals with achievements.

A very important point is, who is going to ask these questions? Mead presents two different approaches that are used in counseling which could easily be applied here. 1

1. The counselor administers psychological tests to the patient, interprets the results, and gives his diagnosis, telling the patient what his problem is.

2. The counselor works with the patient, helps him to discover his problem and to look for solutions, and to use and develop more of his potential.

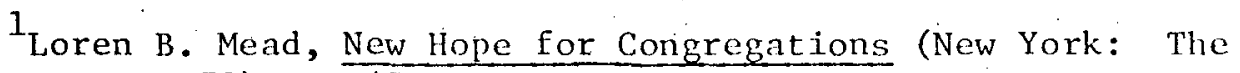
Seabury Press, 1972), p. 47 . 
In the framework of a local congregation, the second approach seems to be the better of the two. Mead marks the positive effects of an "innocent ignorance" manifested by a consultant/advisor in the solving of a local problem. Such a relationship permits questions to be asked which will "bring out in the open issues that had been held. in a conspiracy of silence," giving the opportunity for facing and eventually solving them. ${ }^{1}$ The opposite attitude is the excessive demonstration of "expertise," which could encourage unhealthy dependence upon the consultant.

The role of the clergy in the process of renewal should, then, be instrumental in assisting the congregation to develop its own vitality. The minister cannot provide all the answers.

Information that can draw a picture of the realities of the congregation can be obtained from several sources. Lindgren suggests some sensors through which feedback may be received for a permanent assessment. They are:

1. Internal self-evaluation of mission, structured programs, and leadership.

2. External evaluation from outsiders, supervisors, and colleagues.

3. Periodicaily organized data-gathering from members with particular attention on non-active members.

4. Consistent openness of leaders to receive feedback from

${ }^{1}$ Ibid., p. 100. 
anyone willing to offer honest criticism through personal daily conversation. ${ }^{1}$

There is a danger, however, with the self-assessment procedure. It could be transformed into either a destructive session of criticism with no positive results, or what McNutt calls "morbid introspection." 2 To avoid the first extreme, the remedy is the disposition to change what is deemed necessary to change and not just to lament its existence. The remedy for the second extreme is to use the self-scrutiny as a tool to reach out for the ever-available power of God, the source for change and renewa1. The whole process should be filled with love (the antidote for criticism) and faith (the remedy against desperation).

\section{Planning with the Church}

When applied to a local congregation, the program should begin with a meeting of the church board. The whole idea should be presented, discussed, and necessary adaptations made. The impression of an imposed plan should be avoided in order to foster identification of the board members with the program and achieve maximum participation. The same procedure should be followed with the whole congregation.

\section{Steps in the Process}

The objective of the process is to receive input from present

${ }^{1}$ Alvin J. Lindgren and Norman Shawchuck, Management for Your Church (Nashville: Abingdon, 1978), pp. 66-68.

2 William Roy McNutt, Worship in the Churches (Philadelplia: The Judson Press, 1941), p. $8 \overline{6}$. 
and former members of the congregation. From this input, feelings and perceptions will be assessed by combining subjective and objective evaluation and analyses.

The suggested program will use four basic steps: (1) personal self-evaluation, (2) interviews with disfellowshipped or totally inactive members, (3) a survey among present active nembers, and (4) study groups which will analyze the data received and search for ways to make necessary improvements. The program should be adapted to the local. congregation through the ideas and suggestions presented by the board members and members of the congregation.

Subjective Se1f-Evaluation of the Members

The subjective evaluation of the members is based on three assumptions :

1. The quality of the corporate life of the congregation depends on the quality of the lives of the individual members. The opposite is also true; that is, the quality of the life of the individual member depends on the quality of the corporate life of the congregation. There is a mutual interdependence between the two.

2. The spiritual health of the congregation depends on the quality of the relationships of the individual with his environment. The individual's relationship with the other members of his family, with fellow members of the church and with his neighbors, and his willingness to serve others will all be evaluated.

3. The quality of the spiritual life of the individual is contingent upon his dependence on the source of spiritual strength. 
His prayer life, his devotions, his participation in devotions, and his attendance at church services are sources of spiritual health and will be evaluated. This will establish at the very beginning the right idea that renewal can be achieved by the power and grace of God alone even though man's will plays a very important role in the preparation for the reception of power.

The self-evaluation will be made at the conclusion of the worship service on the first Sabbath morning of the assessment program. The suggested topic for the morning's sermon is the tension the Christian experiences between the call to follow Jesus and the call of the world.

The model for the suggested evaluation is totally subjective. The evaluation requested is based on the church member's degree of self-satisfaction with his present condition concerning the mentioned items. Identification of the respondent is not requested. (See appendix A.)

\section{Interview with Disfellowshipped and Inactive Members}

Ex-members are often considered traitors or enemies of the church. Since the presentation of the parable of the prodigal son, many "older brothers" have been stumbling blocks for returning backsliders. When Jud made a study with ex-pastors of the United Church of Christ, he stated, "The wisdom of the ex-pastors was not being tapped. There had obviously been an institutional failure in listening to . . . these men." He called these ex-pastors an important 
group of people, . . who had given much and have much to give."1

The same could be said of backsliders, among whom there are former church officers and people with long life experiences. Their viewpoint, as they see the church from outside, can be valuable in identifying areas where improvement is necessary. Some very practical rules that should govern this part of the program are:

1. A vital aspect of this visitation program is the manner in which the ex-member is approached. Normally when a backslider faces a miniters or a member of the church, he either locks himself up or adopts an attitude of attack or self-defense. Neither is a positive attitude for good interaction. Since postures might be caused by previous experiences when he may have been treated as an outcast or had been condemned, his present attitude is understandable. It must be remembered that the main motive for this particular visit is not to convince him to return to the fellowship, but rather to secure information and advice to help improve the life of the congregation. The goal is to search for possible hurtful elements that could be eliminated from the present life of the congregation in order to avoid future mistakes. The church is eager to 1isten. This should be made clear at the very beginning of the visit in order to create an open and relaxed atmosphere.

2. The selection of the visitor is a very important issue. It would be ideal if a minister who has not been involved with the life of that congregation, and who would, therefore, be neutral to

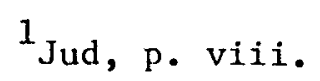


the particular situations mentioned, could be the visiting pastor. This is especially true when there are visible problems in the church--such as ethnic, social, or family divisions among members. Church members who are advocates clearly identified with one side of a church conflict should not be allowed to visit ex-members, because this obviously would close the door to an open interaction. If an impartial minister cannot be the visitor, members from neighboring churches or denominational leaders would make satisfactory substitutes. They would be more able to foster. greater impartiality necessary for a fruitful visitation program. Church members who were involved in the disfellowshipping of the former members should not take part in this phase of the program.

3. The questions should be asked in the most natural way possible, avoiding any semblance of a cross-examination.

4. The visit should be made by appointment. This will avoid unnecessary pressure and will create a more relaxed environment.

5. All the observations made by the ex-member should be received and accepted without defense or justification. The visitor needs to know the facts; the evaluation will come later. Sometimes strong accusations against the ministry, the denomination, and the local leadership of the church might be revealed. The visitor should accept these and make note of every observation or idea, encouraging the person to talk freely. It is relatively easy to discover whether the person is bitter and frustrated or if he is speaking objectively.

6. The visitor should try to assess whether the ex-member's real reasons for dropping out are due to doctrinal problems or to 
human-personal relationships. In other words, if the separation is from the institutional church or from the gospel.

7. The visitor should be sincerely thankful for every. idea expressed and should promise to take them to the church to be studied as they search for ways in which they may improve.

Since the self-assessment by the ex-member is intended to improve the quality of congregational life and the environment of the congregation, the following information should be secured: (See sample form in appendix A.)

1. Age when baptized

2. Means by which the person became acquainted with the church

3. Length of time he/she remained in the church

4. Evaluation of the prebaptismal instruction and postbaptismal care

5. Evaluation of different aspects of the life of the congregation, such as the program, worship services, quality of fellowship, preaching, finances, etc.

6. Evaluation of his/her habits of church attendance and participation in the outreach program.

7. Reasons for dropping out

8. Areas in which, and in what ways, the church could improve

9. Suggestions for diminishing the number of dropouts

Fordyce Detamore, a specialist in this kind of work, suggests several "do's" for those working with backsliders. His principles, 
which are listed below, may be wisely applied to the visitation program described above:

1. Come to the point quickly. This shortens the period of dread and discomfort that is natural in such a visit.

2. Let the bitterness come out. He will probably "unload his pent-up hatred." Listen kindly and interestedly.

3. Don't defend anyone. Defending an "enemy" of the backslider identifies you as an enemy also.

4. Don't betray the backslider's confidence by telling others what should be kept secret.

5. Don't make the visit long. In that way the door is open for another visit.

6. Always close your visit with prayer. ${ }^{1}$

\section{Survey among Members}

A survey to gather information from the current members of the congregation may have its objectives summarized as follows:

1. To discover the quality of the climate of the congregation as felt by the present members.

2. To isolate potential causes for dropouts

3. To discover possible means to correct what may be a source of problems.

A special meeting should be convened for the completion of the survey forms. (See sample in appendix A.) A full explanation

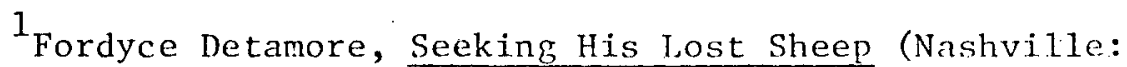
Southern Pub. Assn., 1965) pp.70-75. Other help ful guidelines are given on $\mathrm{pp} .78-82$ in the same book. 
of the objectives for this part of the assessment process should be made before the forms are filled out. It may be advisable to go over the form item by item, allowing time for answers to be written and giving participants the opportunity to ask questions. Every item should be made clear. Anonymity should be honored in the answers to the questions.

One of the results of this survey will be to awaken the interest of the church members to speak openly about concerns they may have but have been afraid or hesitant to express or which they may have shared only in some inner circles. This newly developed openness prepares the way for the last part of the evaluation process, that of forming a clear idea. of the real condition of the church. The same questions and request for opinions which were asked of former members should also be asked of current members.

\section{Study Groups}

Probably the most important aspect of this self-evaluation process is the formation of study groups to investigate aspects of the life of the congregation by which its "character" is manifested. Through the analysis of the self-evaluation, the visit to backsliders, and the survey among members, a more or less clear picture of the health of the church will emerge. Probably some problem areas will be identified, although it is not unusual to discover that no major problems were revealed. Nevertheless, some of the more important areas of the life of the church should be isolated and studied by these small groups. The main concern here is the quality of the 
human climate or "character" of the church. Some significant areas to evaluate could be:

1. Fellowship in the church

2. Worship services

3. Quality of preaching

4. State of finance

5. Missionary programs

6. Prayer meetings

7. The church building

8. The church and the community

9. The church and young people.

In the organization of the study groups, the following steps should be taken:

1. A leader should be selected for each group. Each item on the evaluation list is assigned to a group. The leader's work will be to lead out in the brainstorming process.

2. A meeting will be held for all the leaders. At that time the following items should be discussed:

a. The self-evaluation process up to that point should be reviewed and the objectives for the overall plan

- should be made clear.

b. A clear explanation of the objectives of the study groups and of the approach to the study should be given. In addition, leaders will learn what role they are to play in their groups, how they should elicit participation from every nember, how to 
limit topics, how to avoid fruitless criticism, etc.

c. The mechanism for presenting group reports to the whole assembly should be outlined.

d. Ideas about the subjects to be studied should be shared so that leaders will be better prepared for their leadership role.

3. Consideration should be given to the organization of the church for the discussion groups. There are some practical aspects that should be taken into consideration in this phase of the process.

First, what kind of groups should there be? In smaller

churches where the formation of groups is not advisable, the total membership could analyze together each of the topics at a time set aside for this (either every night of a given week, or once a week during the prayer meetings, or in specially called meetings). The discussion could be preceded by a Bible study about the subject to be discussed and/or prayer bands.

Second, small study groups could meet in private homes, bringing their conclusions later to the plenary session of the church. If the groups met on different evenings of a given week, the pastor could be present at all of them, if that is deemed advisable.

Third, the entire congregation should be invited to a special meeting. The large groups are then divided into smaller groups which caucus and give input to the plenary. According to the interest manifested in the discussions, two or more sessions could be planned. Adequate time should be provided for a calm and relaxed discussion. One and a half to two hours is usually sufficient. 
Every group should appoint a secretary who will gather a11 the ideas discussed by the group and present the report to the plenary session.

Fourth, in a special meeting--which could follow the discussion groups if enough time is available--every group secretary will present the suggestions brought by his or her respective group. At this time additional ideas could be added.

Fifth, the final report of the groups will be published for distribution among the members, who will be asked to make the renewal decision a special subject of prayer. A commitment to achieve the ideal renewal presented will prepare the church for the miracle of renewal that God will surely perform.

\section{Implementation of the Suggestions}

In this kind of planning there is the danger of (1) leaving everything as it was before, giving the plans and suggestions a resting place in the files; (2) spending so much time in planning that the impact of what is being done is diffused; or (3) assuming that renewal is a mechanical task that will be performed by human decisions and efforts. In order to avoid these dangers, the following principles should be taken into consideration:

1. A11 of the processes analyzed above are just the beginning. A good plan occupying a file folder in the file represents a loss of precious time. The objective of all the data gathering is to give intentionality to the church, to show what the goals are, and to determine what means should be used to reach them. Without proper implementation such data gathering is not worthwhile. As 
expressed by Worley, the objective of the church in such a study is "to examine its own understanding and make judgments as to whether the intentions of the congregation express that self-understanding." 1 The result of the evaluation must be the setting up of an ideal to be reached in each of the areas under study. For example, perhaps the quality of the midweek prayer meeting does not fulfill the expectations of the congregation. The diagnosis (present reality) of that service has already been made by one of the study groups, but that is not all that is needed. A model of an ideal prayer meeting should be drawn up by the group with subsequent input from the entire congregation. This model would probably include the ideal time and place for the meetings, the type of preaching or Bible studies to be presented, congregational and special music, and any other characteristics that would produce an ideal spiritual, dynamic, and blessed prayer meeting.

When the model has been completed, pertinent questions should then be asked: How does the present prayer meeting compare with the model? In which aspects should changes be introduced? Do the present music, preaching, and prayer groups reach the ideal? What principles and traditions govern the format of the present prayer meetings? The value of this kind of procedure is that it gives intentionality to the goal to be reached. It is relatively easy to make the necessary changes during the renewal process and to adjust the situation to the model previously prepared. Other main points can be analyzed in the same way and a<smiles>[Y10]C=[Pb]</smiles> 
model, which will become the goal to achieve, should be prepared. Throughout this process positive aspects should be included and negative ones avoided.

All goals should be clear, attainable, and measurable. When idealistic, unrealistic goals are set, the result is frustration. Goals should be measurable so that they can be continuously checked for progress or lack of progress. The basic idea and the way it is formulated should clearly show the church where it wants to go and how to get there. If the goal for worship, for instance, is "to bring the spirit back into worship," the goal is not clear. Worley calls this a "pious statement which may have excellent intentions behind [it]," but which lacks a "model description of what the outcome would look like if the group were effective." 1

It is suggested that members of the discussion groups could well be transformed into special committees to implement the ideas they had presented to the church and which were accepted by the congregation.

The minister plays a very important role in the implementation of the whole program, but he must be very careful not to manipulate the congregation--one of the easiest things to do through the pulpit. However, the pulpit is a good place to voice the needs of revival and to lay the foundations for it.

Juan Carlos Ortiz says: "We preach a truth until the church lives it." For instance, the Bible says, "Husbands, love your wives" (Eph 5:25). He will preach that for two or three weeks until all the husbands are loving their wives. 2

$1_{\text {Ibid., p. } 1.05 .}$

Robert Munger. "Purpose, Priority and Planning as Factors of kenowat of a location Congrenation" (Syllabus for Seminar on Church kenewal) ((irand Rilpids, July 1979), n.p. 
The needs of the congregations, the ways to fulfill those needs, and the power of Christ to complete that renovation have to be stressed until Christ, through the decision of the congregation, fills all their needs. This is the way by which the problems that the congregation discovered during the data-gathering process can be solved.

The words of Engstrom and Dayton are a good summary: "An effective organization needs clear and communicable goals, adequate resources, motivated people, and good communication." 1

2. The second danger is spending so much time in planning that the impact of what is being done is soon spent. It is not encouraging to keep going if results are not seen. If the church spends too long a time with committee meetings without getting the job done and witnessing some fruits, boredom and frustration will put an end to the whole program. Careful planning and decided action should take place as soon as the objectives and goals are clear.

The plan suggested in this paper would accomplish the entire process of planning, self-assessment and goal setting in just three intensive weeks. The recommended schedule for this would be:

Day 1. Presentation of the idea to the church board, and upon acceptance, establish the method to be used in the local congregation.

Day 8. The whole program is announced to the congregation during a specially called administrative meeting which receives

$1_{\text {Ted }} \dot{W}$. Engstrom and Edward R. Dayton, The Art of Management for Christian Leaders (Waco, Texas: Word Books, 1976), p. 109 . 
feedback to be used in the preparation of the final plan.

Days 9-14. Questionnaires and other materials prepared.

Days 15-23. Intensive process of self-evaluation during a special week of prayer (week of spiritual emphasis), to include the following activities:

Day 15, Steps 1,2. General survey and self-evaluation of the members of the church

Day 16, Step 3. Visitation of backsliders

Days 17-19, Step 4. Study groups working

Days 20-23, Step 5. Report of study groups, elaboration of general plan formulated. The implementation of the program begins immediately.

3. The third danger is believing that renewal is a mechanical task performed by human decisions and efforts. "Unless the Lord builds the house, those who build it labor in vain" (Ps 127:1, RSV). A spirit of prayer should permeate the work during the whole process. The church is not a secular-human organization whose functions are based on human plans and inspirations. Men can permit or reject the operation of the Holy Spirit, but cannot do what is the work of God. During the whole process the task of the congregation is to open their hearts to the light of the Holy Spirit, who will enable them to see where changes need to be effected. It is the power of God that will do the cleansing.

\section{Continuous Evaluation}

Continuous evaluation of what is taking place is a last 
necessary step. Its objectives are. (1) to check whether the goals are being achieved, and (2) to check whether the fruits of the program are affecting the life of the church. A sensoring system should be built into the church so that it will be alert to the environmental changes. Feedback needs to be taken seriously and objectively. It should be evaluated and acted upon. Feedback comes from various sources:

1. Frequently the clearest feedback is behavioral: complaints, reduced participation, financial withholding, and poor attendance are some of the signs that show a negative response. The positive signs for the success of the program are: improved attendance, active participation, improved finances, and a happy atmosphere where differences and resentments have disappeared. ${ }^{1}$

2. Internal self-evaluation using the same instruments could be repeated after some time. The first experience will make the second easier and more accurate.

3. External evaluation from pastoral colleagues, denominational leaders, and members of other churches.

4. Daily contact among members who are willing to offer honest, open, critical opinions.

The whole process of self-assessment and goal setting could be summarized in a two-step cycle that was followed by one of the churches analyzed by Anderson and is shown in figure $3 .^{2}$ The same process can be presented in a six-stage sequence, which agrees

${ }^{1}$ For a complete study of this aspect, see Engstrom and Dayton, pp. 66-68.

${ }^{2}$ Anderson, p. 132 . 
or

EVALUAT ION

ACTION

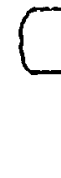

Fig. 3. Two-step cycle for a self-assessment and goal-setting process

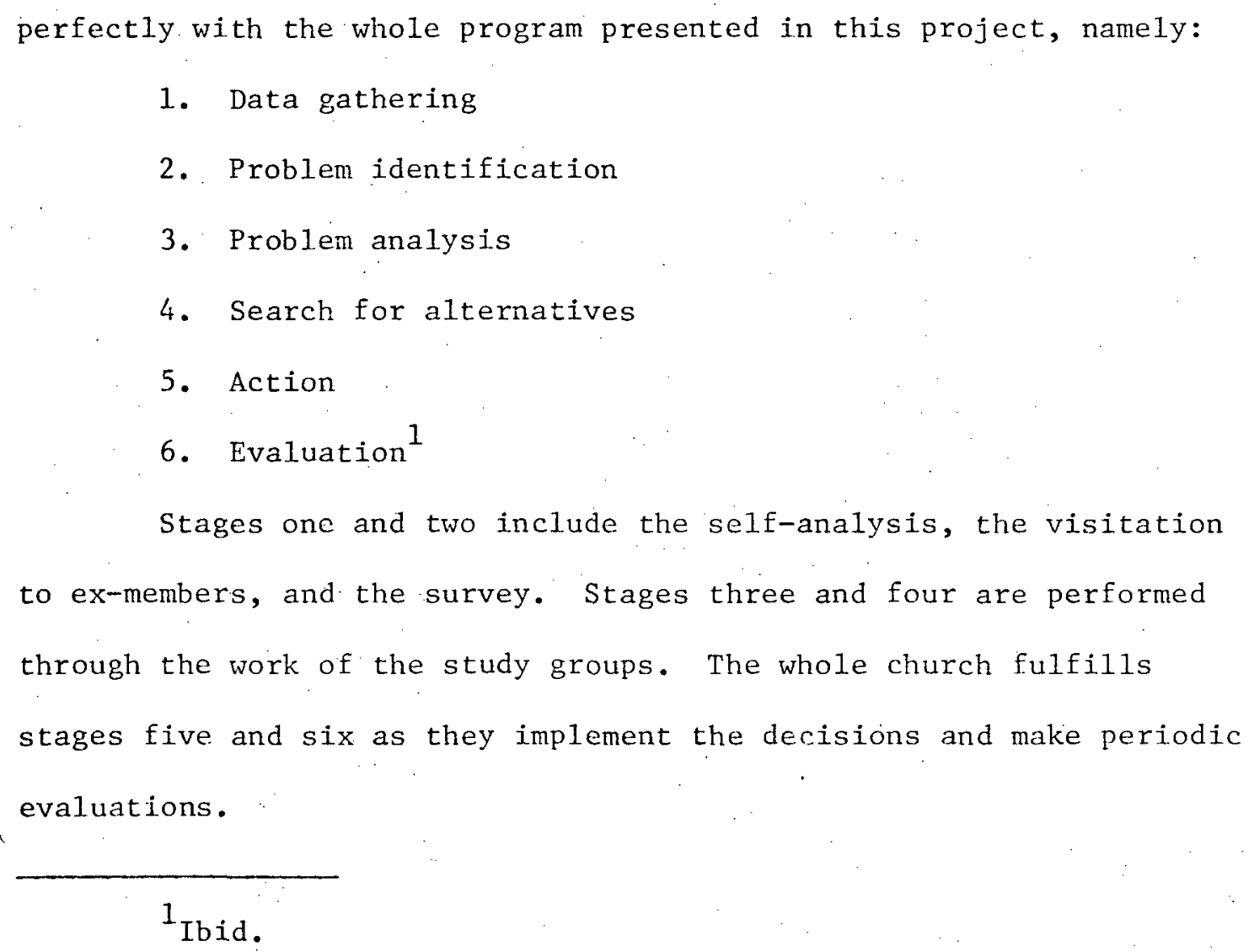




\section{CHAPTER V}

\section{ANALYSIS OF THE TEXAS EXPERIMENT}

Having established the need for a program of self-assessment as a prior step to the implantation of changes in a congregation in order to achieve renewal, a place was selected to test the program. The purpose of this chapter is to analyze project activities involving three ${ }^{1}$ congregations in the state of Texas. A brief history of the churches is followed by the analysis of the results of the various steps of the program.

\section{The Churches Studied}

The Spanish-speaking congregations of Dallas and Houston were selected for this experiment, and arrangements. were made with the Texas Conference of SDA for a field test of the program proposed in this study. The field tests were planned during November and December 1979 and were conducted in an intensive way during January and February of 1980 . Dallas, The Oak Cliff Church

Its history. The present Oak Cliff SDA Spanish church began as a small group of believers in the 1960 s and was a part of the American congregation. In 1967 the original congregation moved to new facilities, leaving the building to the newborn congregation. At that time the first pastor was appointed. Highlights of the

\section{$1_{\text {See p. }} 73$.}


story of the congregation are as follows:

1972-1977 - The pastorate of Norberto Mulinari was characterized by a strong evangelistic emphasis. The congregation grew from eight to 110 members.

1977-1979 - During the pastorate of Onesimo Mejia, a new congregation--the North Church--was organized (August 1979) and a strong evangelistic campaign was conducted (September-0ctober 1979). The membership increased by 108 new members.

1979 - In October of 1979 Tony Vargas was appointed as the new pastor.

Eighty percent of the present church members are Mexican immigrants. The other 20 percent are Americans with Mexican background. The original plan comprised one entire month of activities involving the two congregations of Dallas. The North Church, however, was unable to secure the facilities of its rented building for an entire week of nightly meetings. Therefore, its members were invited to join the Oak Cliff Church for the program. In this study the two churches are called "Dallas."

Another problem arose two weeks before the beginning of the program. The pastor, due to a serious illness of a relative, had to leave Dallas, and was unable to return until two days before the close of activities. Because of this the program was organized, prepared, and carried out without his presence and counsel. The implementation of the suggestions given by the study groups (at the end of the self-assessment program) depended upon the enthusiasm of the congregation which was thus required to lead the pastor through 
a program which he had not personally experienced. Houston, The Robertson Church

Its history. The history of the congregation began in 1944 with the conversion of the first Spanish-speaking couple. Some of the important events of its history include:

1964 - A small group of believers left the American church and began meeting in a rented home.

1968 - The inauguration of the new church building. 1972 - An evangelistic campaign was conducted by Braulio Perez Marcio, director of "La Voz de la Esperanza" radio program. 1969-1908 - The pastorate of Ben Colon

Almost the entire congregation is Mexican-American. At the beginning of 1980 the church had 180 members.

Although the program was not originally planned for Houston, Pastor Ben Colon accepted it with enthusiasm when part of the activities of Dallas were cancelled. He totally cooperated with the selfassessment and goal-setting portions of the program. The congregation also cooperated with enthusiasm throughout the project.

\section{The Process of Self-Assessment}

The schedule suggested in chapter IV was followed in the two churches. In the following pages, a description of the activities of each phase of the program is made.

Step 1. Personal Analysis

To begin the self-assessment process, the members of each 
church filled out a self-evaluation sheet on which they rated the following aspects of their personal lives on a scale of one to ten:

1. Prayer life

2. Devotiona]. reading

3. Faith

4. Attendance at the services of the church

5. Confidence in the church

6. Stewardship

7. Personal witnessing

8. Willingness to serve

9. Family worship

10. Relationship with husband/wife

11. Relationship with children

12. Relationship with parents

13. Relationship with fellow members of the church

14. Relationship with neighbors (See appendix A.)

As explained earlier, ${ }^{1}$. this is a subjective evaluation on the part of the congregants based on the degree of satisfaction or dissatisfaction experienced with their present habits or customs in these important areas. To avoid "morbid introspection,"--a common practice among some religious persons,--the achievement of a positive climate was attempted by means of a sermon preached prior to the self-evaluation process. The purpose of this evaluation was also fully explained, and the ever-present power of Jesus Christ was 
pointed out as the answer to any weaknesses which might surface. This thought is also included in the questionnaire used. (See appendix A.)

The evaluation had two main objectives: to help confront the respondent with his personal situation in these matters and to serve as an instrument of evaluation of the congregation as a whole. The evaluation sheets returned (63 in Dallas and 47 in Houston) served as the basis for a profile of the church. Because the responses of all members were not included in this material, the profile must be considered as representative of the perceptions of those who chose to return the sheets. However, the varied responses did give some indicators of the concerns of the members. This kind of evaluation is of value because it produces a confrontation between the individual and his present situation in vital aspects of his 1ife. It also serves to open up opportunities for the pastor, who is provided a profile of the needs of the corporate group, to help people who are in need. For example, in Dallas, satisfaction with personal "devotional reading" ranked lowest while "church attendance" ranked highest (figure 4). In Houston, the lowest ranked was "family worship" and the highest was "relationshipwith parents (figure 5).

Comparing the two churches on the basis of the results of the Personal Analysis questionnaire, one notes some unexpected results as well as a confirmation of some rather obvious items visible to those who are acquainted with the two congregations. The results of the profile indicate that the respondents from Dallas felt better about their church (average of 7.44 on a scale of 0 to 10 ) than did 


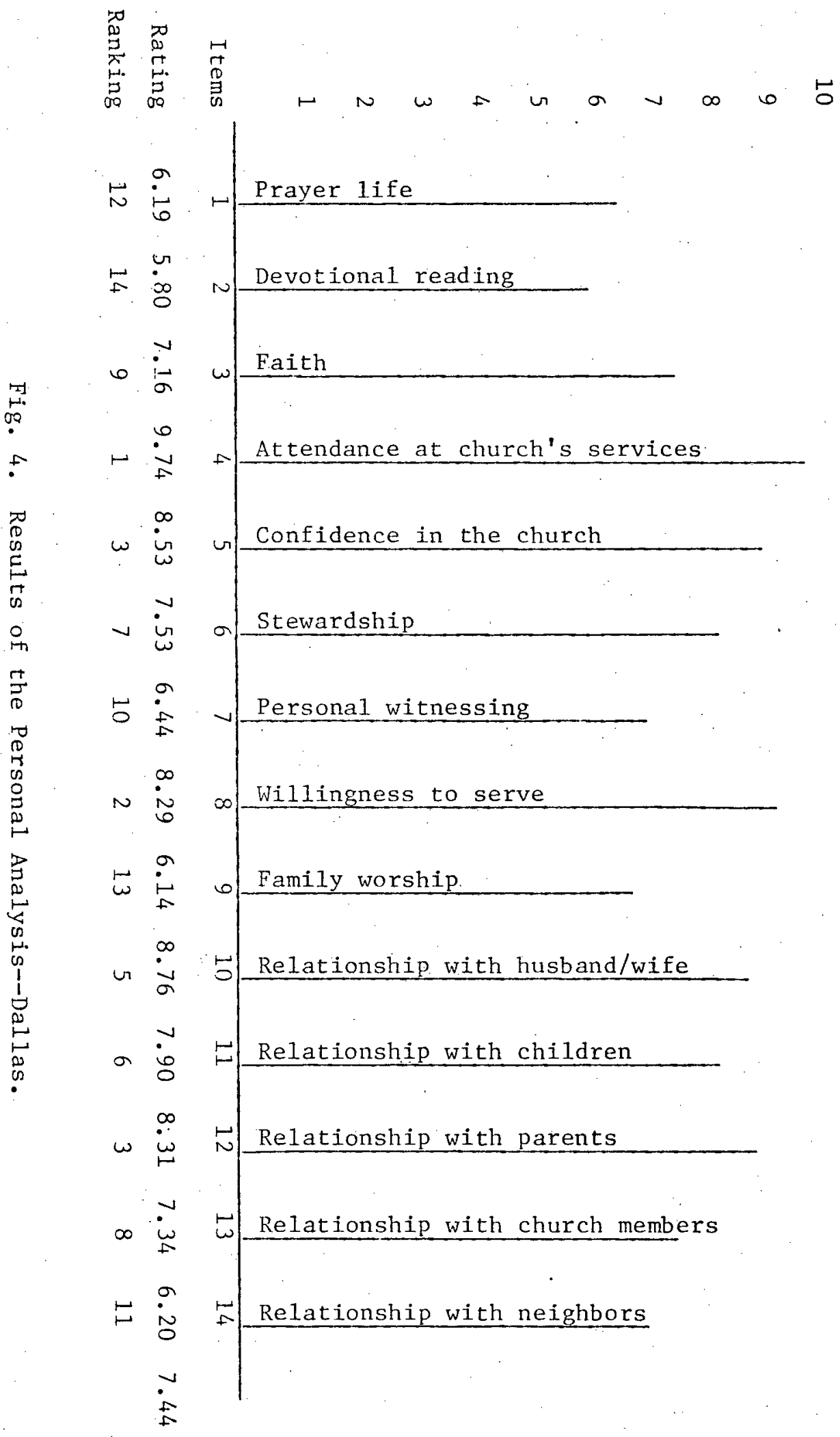




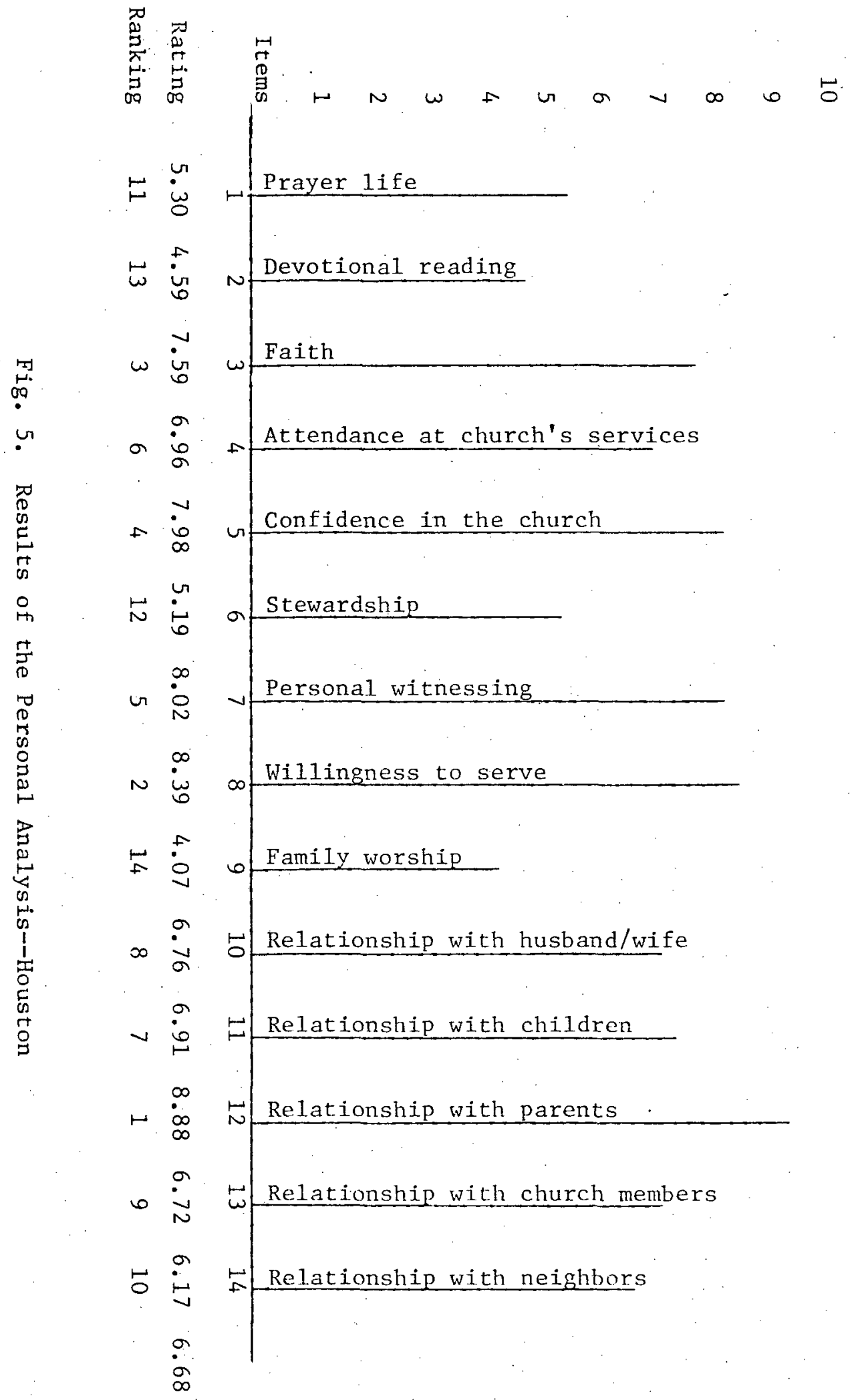


those from Houston (average of 6.88 ). This attitude was also apparent in the church atmosphere. From the profiles, the church in Dallas appears to be much more alive, its singing more vigorous, attendance at meetings much better. Thus the instrument appears to corroborate what may be observed in the church.

Another surprising, although understandable, contrast is seen in the evaluation of stewardship. Dallas rated "stewardship" 2.34 above Houston's rating. However, it was insistently mentioned during the entire process that financial drives were emphasized too heavily in Houston. One might ask if the difference in ratings in this area might be an indication of weakness in the approach to financial promotion. The former pastor of Dallas had worked as stewardship director at the union level previously. Perhaps his competence in this area is reflected by the survey in which stewardship sermons were given a high ranking--third place--in Dallas (after those relating to prophecies and the Christian life. In Houston stewardship sermons were ranked in eighth place.

In other areas, the profile suggests differences difficult to explain. In Dallas, respondents gave a low ranking to satisfaction with their prayer and devotional life (rank of twelve and fourteen respectively) and admitted poor habits regarding family worship (rank of thirteen), yet considered their faith and witnessing to be better (rank of nine and ten respectively). It would seem that these items should be more closely related. Figure 6 shows a comparison between Dallas and Houston on the fourteen areas covered in the selfassessment. 


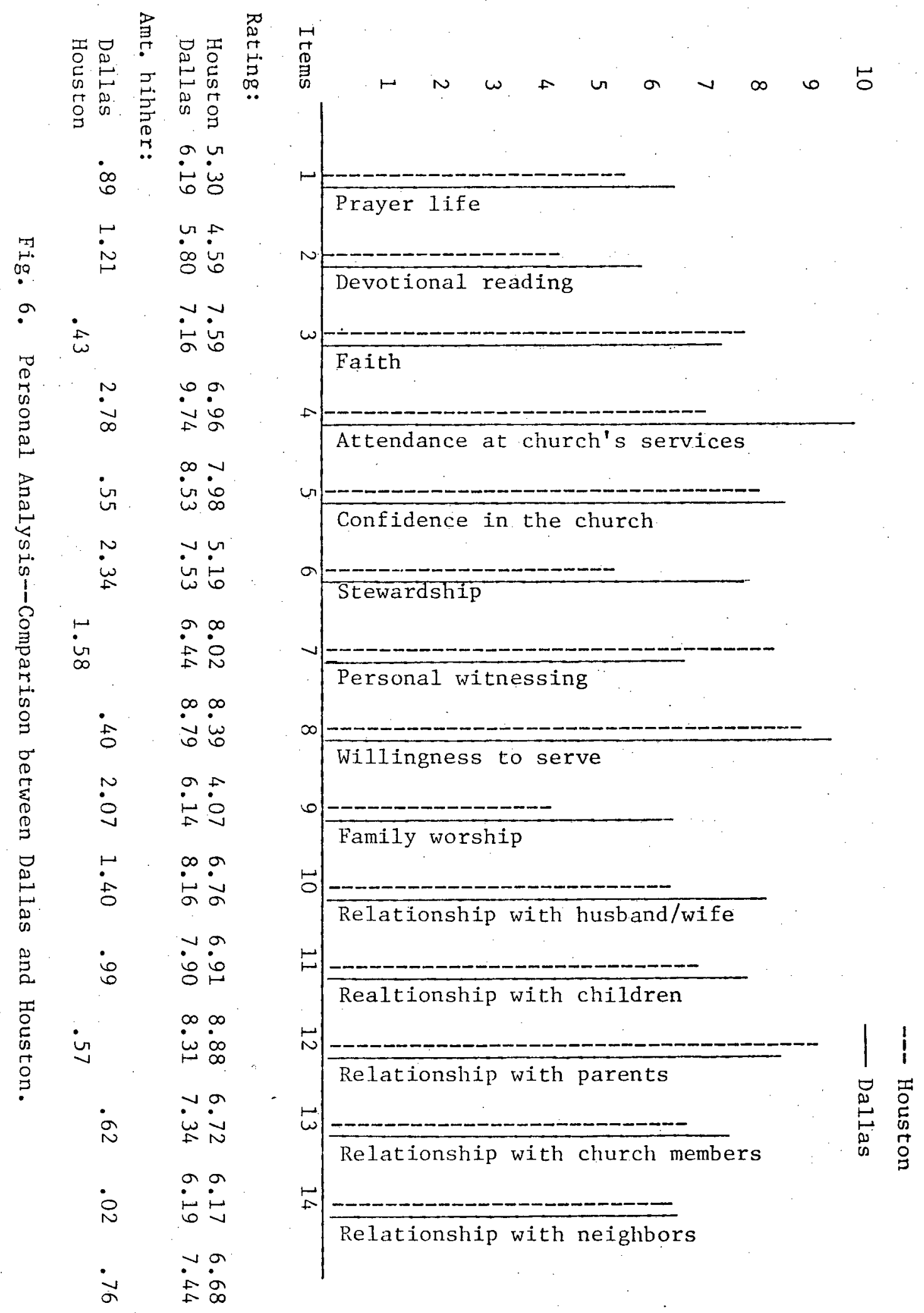


Step 2. Visitation of Backs1iders

As noted earlier, a part of the overall program includes visitation of backsliders. This part of the program was not carried out in either church because of the paucity of identifiable dropouts. The churches were both relatively new. It was discovered that persons referred to as dropouts were no longer in the area. There is a high degree of mobility among the Spanish-speaking people in the southern part of the United States. The proximity to the Mexican border and the constant search for new horizons produce a high degree of movement in the region. In other cases there was a lack of accurate information as to addresses or location of dropouts. It was concluded that the number of persons visited was inadequate to be able to reach definite conclusions.

\section{Step 3. Survey among Members}

The main objective of the membership survey is to attempt to view the congregation from within. It is an opportunity for the members to express freely through a questionnaire (see appendix A) what they like and what they dislike in the life of their congregation, not as an accusation, but rather as a diagnosis. The manifestation of bitter feelings, unfortunately, is sometimes inevitable in this part of the evaluation process. The expression of these fee1ings is encouraged, however, as a necessary and healthful step in the process of healing and improvement.

Indispensable to this stage is the next phase, in which members are brought together in groups for purposes of diagnosis and to 
search for means of improvement. Without this the survey could result in a negative experience.

The instrument employed to gather information was prepared with the definite purpose of measuring those elements or situations which appear to contribute to disassociation from the church. Basic assumptions to be examined by the data included:

1. Dropouts from the SDA fellowship are not produced by theological disagreement but by the quality of the internal life of the congregations.

a. The doctrines of the SDA church are clear and are not a cause for dropouts.

b. Deficiencies in the quality of human relations and fellowship among members of the congregation contribute to dropouts from the church.

c. Deficiences in the quality of worship and preaching result in spiritual undernourishment, which also contributes to an increase of dropouts.

2. There are enough resources and good will among SDA church members to face these problems and solve them.

As a step toward testing these assumptions, the members of the churches involved in the study were invited to a special meeting on a Sabbath afternoon. After a short spiritual message and an explanation of the objectives of the survey, questionnaire no. 3 was distributed. Assurances were given with respect to anonymity and confidentiality. A total of 110 forms were filled out in Dallas and seventy-eight in Houston. Although much of this information will be 
examined in connection with the analysis of the stury groups, some general aspects are noted here.

The respondents

Sex. Of the respondents from Dallas, 50 percent marked "male" and 46.4 percent marked "female." In Houston more respondents marked "female" (53.9 percent) than "male". (43.6 percent). Thus, 49.5 percent of the total responses were given by women and 47.3 by men; the remaining 3.2 percent did not indicate their sex.

Age. The churches involved in this survey are composed of a high percentage of young people, as presented in table 5 . This is frequent1y the case in Latin-American congregations. Obviously, a

TABLE 5

PRESENT AGE OF THE RESPONDENTS OF THE SURVEY IN DALLAS AND HOUSTON

\begin{tabular}{l|rrr}
\hline \multirow{2}{*}{ Age } & & Percentage & \\
\cline { 2 - 4 } & Dallas & Houston & Average \\
\hline $11-15$ & 1.8 & 1.3 & 1.6 \\
$16-20$ & 12.7 & 24.4 & 17.5 \\
$21-25$ & 13.6 & 16.7 & 14.9 \\
$26-30$ & 20.9 & 21.8 & 21.3 \\
$31-35$ & 9.1 & 6.4 & 8.0 \\
$36-40$ & 8.2 & 5.1 & 6.9 \\
$41-45$ & 9.1 & 6.4 & 8.0 \\
$46-50$ & 5.4 & 6.4 & 5.9 \\
$51-55$ & 0.9 & 2.6 & 3.7 \\
$56-60$ & 4.5 & 2.6 & 3.7 \\
$61-65$ & 4.5 & 2.6 & 2.1 \\
$66-70$ & 2.7 & 1.3 & 0.5 \\
$71-75$ & 0.9 & - & - \\
$76-80$ & - & - & \\
81 or older & - & - & \\
\hline
\end{tabular}


high percentage of them were baptized very young. (See table 6.)

Background. Two types of background were considered important--that of the family and the religious background. Two factors may explain the large number of young people in the church and early baptism: (1) In general, Mexican families are large, and (2) there is a special relationship between parents and children, as already noted in the Personal Analysis. Parents at Dallas evaluated their relationship with their children as being positive ( 7.9 on a scale of one to ten); those in Houston gave a slightly lower rating (6.9). The children evaluated their relationship with their parents at 8.3 in Dallas and 8.9 in Houston. Family unity is normally well preserved in the Latin-American culture. This may explain the large number of respondents who reported the family as the means through which they came to the church (table 7).

The religious background is also important. As. Catholicism is strong in Mexico, it is understandable that a larger number of respondents have a Catholic background. (See table 8.) If these data seem to contradict those presented in table 7 , it must be remembered that when someone immigrates from Mexico to the United States, there are close bonds with other family members who have preceded him. Usually these family members provide shelter, food, and often their religious convictions. Many relatives of Seventh-day Adventists leave the Catholic church in order to become Adventists. The percentage of former Catholics is higher in vallas than in Houston; perhaps due to the more frequent evangelistic campaigns conducted there. It has been observed that Catholics are easier to win by this means than are 
Protestants. In Houston there has been some interaction between members of the SDA church and those of the Church of God, Seventh-day. This explains the incidence of accessions from that confession.

TABLE 6 .

AGE OF BAPTISM OF THE RESPONDENTS OF THE SURVEY IN DALLAS AND HOUSTON

\begin{tabular}{|c|c|c|c|}
\hline \multirow{2}{*}{ Age } & \multicolumn{3}{|c|}{ Percentage } \\
\hline & Dallas & Houston & Average \\
\hline 10 or under & $\cdots$ & - & - \\
\hline $11-15$ & 30.0 & 33.3 & 31.4 \\
\hline $16-20$ & 16.4 & 15.4 & 16.0 \\
\hline $21-25$ & 18.2 & 15.4 & 17.0 \\
\hline $26-30$ & 11.8 & 14.1 & 12.8 \\
\hline $31-35$ & 6.4 & 6.4 & 6.4 \\
\hline $36-40$ & 0.9 & 2.6 & 1.6 \\
\hline $41-45$ & 1.8 & 3.8 & 2.7 \\
\hline $46-50$ & 3.6 & - & 2.1 \\
\hline $51-55$ & 1.8 & - & 1.1 \\
\hline $56-60$ & 0.9 & - & 0.5 \\
\hline $61-65$ & 0.9 & - & 0.5 \\
\hline $66-70$ & 0.9 & 1.3 & 1.1 \\
\hline $71-75$ & - & - & - \\
\hline $76-80$ & - & - & - \\
\hline 81 or older & - & - & - \\
\hline
\end{tabular}

The evaluation of the church

This section analyzes and comments on the evaluations given by the respondents from Dallas and Houston about their church.

General responses

Before analyzing the reactions of special groups in the congregations, a general comparison of reactions between the two churches is presented. 
TABLE 7

MEANS BY WHICH THE RESPONDENTS CAME TO THE CHURCH

\begin{tabular}{l|ccc}
\hline \multirow{2}{*}{ Means } & \multicolumn{3}{c}{ Percentage } \\
\cline { 2 - 3 } & Dallas & Houston & Average \\
\hline Family & 61.8 & 53.8 & 58.5 \\
Friends & 15.4 & 24.4 & 19.1 \\
Evangelistic campaign & 12.7 & 2.5 & 8.1 \\
Literature & 2.7 & 6.4 & 4.2 \\
School & - & 2.6 & 1.1 \\
Radio & 2.7 & 3.8 & 3.2 \\
Other & 2.7 & 2.6 & 2.7 \\
\hline
\end{tabular}

TABLE $\cdot 3$

RELIGIOUS BACKGROUND OF THE RESPONDENTS

\begin{tabular}{l|ccc}
\hline \multirow{2}{*}{ Denomination } & \multicolumn{3}{|c}{ Percentage } \\
\cline { 2 - 4 } & Dallas & Houston & Average \\
\hline Roman Catholic & 37.3 & 20.5 & 30.3 \\
Baptist & 3.6 & 1.3 & 2.7 \\
Presbyterian & 0.9 & - & 0.5 \\
Pentecostal & 0.9 & 1.3 & 1.1 \\
Methodist & 1.8 &.- & 0.9 \\
Church of God, 7th Day & & 7.7 & 3.2 \\
\hline
\end{tabular}


First impressions. One of the questions asked was, "What impressed you most the first time you came to the church?" Table 9 shows the response to this item. Those who came to the church appear not to have been attracted by the material facilities nor other secondary elements but by a biblical, prophetic message. The data indicate, however, that other factors play a part in attracting people to the church, namely, the quality of the pastor, the people, the program, and finally, the material facilities.

TABLE 9

WHAT MOST IMPRESSED NEWCOMERS

\begin{tabular}{l|ccc}
\hline \multirow{2}{*}{$\begin{array}{c}\text { Most } \\
\text { Impressed By }\end{array}$} & \multicolumn{3}{c}{ Percentage } \\
\cline { 2 - 4 } & Dallas & Houston & Average \\
\hline Building & 1.8 & - & 1.1 \\
Message & 53.6 & 59.0 & 56.0 \\
Pastor & 9.1 & 7.7 & 8.5 \\
People & 12.7 & 10.3 & 11.7 \\
Program & 6.4 & 6.4 & 6.4 \\
Other & 6.4 & 6.4 & 6.4 \\
\hline
\end{tabular}

Activities of the church. A rather positive picture emerges from the evaluation given with respect to church activities, as can be noted on table 10. This item encompassed attendance at the services, the missionary outreach program, the ingathering program, etc. It was viewed as a general way to obtain a feel of members' attitudes 
towards the church as a whole. A complement to this is the instrument evaluating member's perceptions as to the effectiveness of the programs carried out by the church. Again, this survey included the programs to fulfill both the internal and the external responsibilities of the church. The objective of this question was the same as the previous one, to elicit an expression of members' attitudes toward the church and its quality of 1 ife.

TABLE 10

EVALUATION OF THE DEGREE OF ENJOYMENT OF PARTICIPANTS IN THE GENERAL ACTIVITIES OF THE CHURCH

\begin{tabular}{l|ccc}
\hline \multirow{2}{*}{ Degree of enjoyment } & \multicolumn{3}{c}{ Percentage } \\
\cline { 2 - 4 } & Dallas & Houston & Average \\
\hline Burdensome & 2.7 & 7.7 & 4.8 \\
Necessary Duty & 10.0 & 3.9 & 7.4 \\
Enjoyable & 53.6 & 57.7 & 55.3 \\
$\begin{array}{l}\text { Major source of } \\
\text { satisfaction }\end{array}$ & 30.0 & 23.1 & 27.1 \\
\hline
\end{tabular}

As can be seen in table 11, there appears to be satisfaction with the church program as a whole. Percentages in the "ineffective" column are low. This tends to confirm the opinions expressed in the Personal Analysis, when confidence in the church was given 8.53 (on a scale of one to ten) in Dallas and 7.98 in Houston.

When asked to express their opinion about the reaisons why people leave the church, "Doctrinal Disagreement" was rated as 7.3 percent in Dallas, whereas this cause was not listed at all in 
Houston. These causes of disaffection must be sought in another area.

TABLE 11

EVALUATION OF THE DEGREE OF EFFECTIVENESS OF THE PROGRAMS OF THE CHURCH

\begin{tabular}{l|ccc}
\hline \multirow{2}{*}{$\begin{array}{c}\text { Degree of } \\
\text { effectiveness }\end{array}$} & Pallas & Houston & Average \\
\cline { 2 - 4 } Ineffective & - & 9.0 & 3.7 \\
Partially effective & 25.4 & 37.2 & 30.3 \\
Quite effective & 50.0 & 27.0 & 40.4 \\
Very effective & 21.8 & 15.4 & 19.1 \\
\hline
\end{tabular}

Internal environment. An evaluation of four aspects of the human relationships among members may reveal: some of those weaker areas. Section B of the survey (appendix A) deals with four aspects of those relations, namely; unity among, members, fellowship, care for visitors and affirmation, as they exist in the church. Figure 7 compares the present situation in Dallas and Houston.

It appears that there is a great need for improvement in this area. In the Bible, and remarkably so in the New Testament, the demonstration of love among the children of God is considered as a key element, first as a demonstration of union with the Deity (John $17: 21,23 ; 13: 35$ ), and second, as a way to manifest the love of God for the well-being and salvation of others (Matt 7:21-29). This kind of brotherly love is the fulfillment of the 1aw (Rom 13:10; 
Dallas.

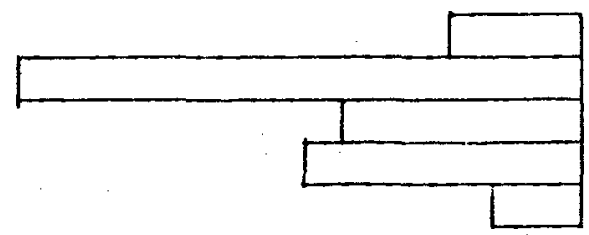

\section{Unity}
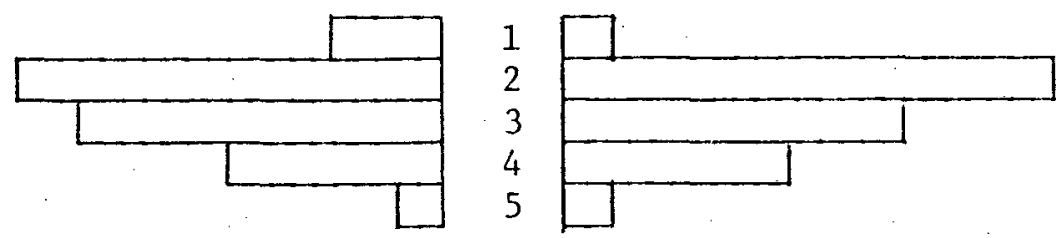

Fellowship
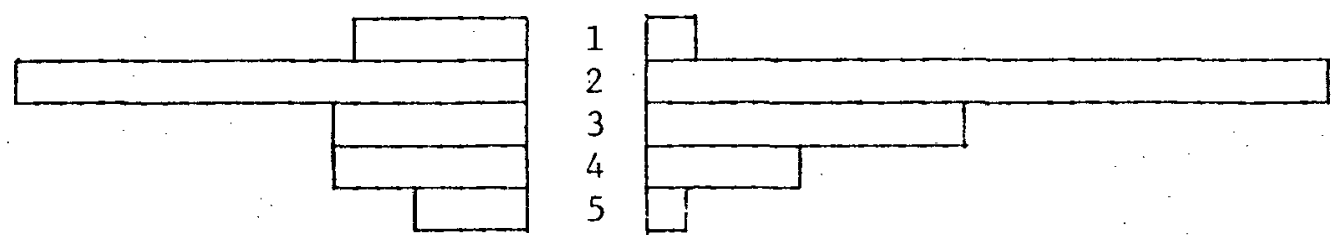

Visitors
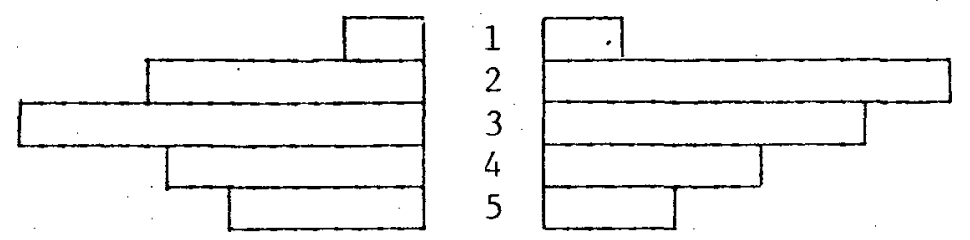

Affirmation

$$
\begin{aligned}
& 1=\text { zero } \\
& 2=\text { poor } \\
& 3=\text { fair } \\
& 4=\text { good } \\
& 5=\text { outstanding }
\end{aligned}
$$

Fig. 7. Evaluation of the quality of four aspects of the internal environment of the church, Dallas and Houston 
Matt $22: 38$, 39; Deut $6: 5$; Lev 19:18), is a fruit of the Spirit

(Ga1 5:22), and without it the church would be like any other institution, devoid of the attributes of a superior institution ( 1 Cor 13).

The last question in the survey asked about the main cause for loss of interest and dropout among members. Table 12 shows the reasons suggested by the respondents.

TABLE 12

$$
\begin{aligned}
& \text { CAUSES FOR LOSS OF INTEREST AND DROPOUT AS GIVEN } \\
& \text { BY PRESENT MEMBERS OF THE CHURCH }
\end{aligned}
$$

\begin{tabular}{l|ccc}
\hline \multirow{2}{*}{ Cause } & \multicolumn{3}{c}{ Percentage } \\
\cline { 2 - 3 } & Dallas & Houston & Average \\
\hline Doctrinal disagreement & 7.3 & - & 4.5 \\
Problems among members & 47.3 & 47.4 & 47.3 \\
Problems with leaders & 3.6 & 2.6 & 3.2 \\
Problems of the & & & 18.1 \\
individual & 15.5 & 21.8 & 8.5 \\
Lack of pastoral care & 1.9 & 18.0 & 1.6 \\
\hline
\end{tabular}

The respondents from the two churches appear to have given a self-diagnosis of the potential causes for apostasy. Their responsibility now is to remedy the situations fostering backsliding. Worship. Several questions were asked regarding different aspects of the worship services: reverence, preaching, enjoyment, 
and attendance. There is a very common problem among most of the Latin-American congregations: lack of reverence. It seems to be caused mainly by two factors: (1) a large number of children, and (2) the typical Latin character which tends to be noisy, spontaneous, and even irreverent. The situation in Dallas and Houston is not different from what might be expected. Table 13 shows the evaluation of this particular problem by the members of the two churches.

TABLE 13

EVALUATION OF REVERENCE IN THE CHURCH

\begin{tabular}{l|ccc}
\hline \multirow{2}{*}{ Degree of Reverence } & \multicolumn{3}{c}{ Percentage } \\
\cline { 2 - 4 } & Dallas & Houston & Average \\
\hline Poor & 40.0 & 52.6 & 45.2 \\
Average & 25.4 & 20.6 & 23.4 \\
Good & 24.6 & 15.4 & 20.7 \\
Excellent & 5.4 & 9.0 & 6.9 \\
\hline
\end{tabular}

Item 25 reads: "Worship services, in my opinion, are: du11, routine, average, inspiring, outstanding." The results obtained are shown in table 14. The picture might be considered positive. Nevertheless, the effects upon the 18.6 percent of the respondents who felt the worship services were dull or routine, should be adequate reason for the church to seek for improvement.

Respondents were asked to indicate at which church services they felt God's presence most. The highest rating was given to the 
Sabbath worship service, although there was a difference in preference between the two churches. The other services were also rated differently by the two groups. The data presented in table 15 show that Sabbath and midweek prayer services are rated lower in Houston than in Dallas, whereas the Sabbath School has a higher rating in Houston than in Dallas.

TABLE 14

EVALUATION OF QUALITY OF. WORSHIP SERVICES

\begin{tabular}{l|ccc}
\hline \multirow{2}{*}{ Quality of worship } & \multicolumn{3}{c}{ Percentage } \\
\cline { 2 - 4 } & Dallas & Houston & Average \\
\hline Dul1 & - & 3.8 & 1.6 \\
Routine & 14.5 & 20.5 & 17.0 \\
Average & 30.9 & 32.1 & 31.4 \\
Inspiring & 30.0 & 30.8 & 30.3 \\
Outstanding & 20.0 & 11.5 & 16.5 \\
\hline
\end{tabular}

TABLE 15

FEELING OF GOD'S PRESENCE AT THE SERVICES

\begin{tabular}{l|ccc}
\hline \multirow{2}{*}{ Service } & \multicolumn{3}{c}{ Percentage } \\
\cline { 2 - 4 } & Dallas & Houston & Average \\
\hline Sabbath School & 16.6 & 33.0 & 23.1 \\
Sabbath worship & 58.9 & 47.2 & 54.5 \\
Prayer meeting & 23.8 & 17.6 & 20.2 \\
Other & 0.7 & 2.2 & 1.2 \\
\hline
\end{tabular}


It appears that the respondents object to some aspects of the preaching services. An evaluation of the quality of preaching in the two churches, as shown in table 16, clarifies this problem.

TABLE 16

EVALUATION OF PREACHING

\begin{tabular}{|c|c|c|c|}
\hline \multirow{2}{*}{ Quality of preaching } & \multicolumn{3}{|c|}{ Percentage } \\
\hline & Dalilas & Houston & Average \\
\hline Poor & 2.7 & 7.7 & 4.8 \\
\hline Routine & 14.5 & 42.3 & 26.1 \\
\hline Cha1lenging & 10.0 & 6.4 & 8.5 \\
\hline Inspiring & 33.6 & 20.5 & 28.2 \\
\hline Excellent & 25.4 & 11.5 & 19.7 \\
\hline
\end{tabular}

In Dallas, preaching is considered more positively than in Houston, where "routine" was the category most frequently chosen. This is another field where much improvement should be found. Is there a correlation between the quality of preaching and attendance at the different meetings? Attendance at the three services is lower in Houston than in Dallas. Table 17 includes all those respondents who rated their attendance as "5" on a scale of zero to five. A cause-effect relationship cannot, of course, be established on this evidence alone, but it could be a good topic for further research. were open ended and members were encouraged to give a written opinion 
or evaluation. These answers are briefly summarized here. The percentages presented are based on the total number of answers given to each particular question.

TABLE 17

REGULAR ATTENDANCE AT THE THREE MAIN WEEKLY SERVICES OF THE CHURCH

\begin{tabular}{l|ccc}
\hline \multirow{2}{*}{ Service } & \multicolumn{3}{c}{ Percentage } \\
\cline { 2 - 4 } & Dallas & Houston & Average \\
\hline Sabbath school & 79.1 & 61.5 & 71.8 \\
Sabbath worship & 83.6 & 75.6 & 80.3 \\
Prayer meeting & 33.6 & 15.4 & 26.1 \\
\hline
\end{tabular}

"What do you like best in the church?" The answers given to this question were grouped into five general categories in Houston and six in Dallas, as shown in the following summary:

1. Houston

Percentage

a. The message of the church 30.3

b. The services (preaching, Sabbath school, youth meeting, worship on Sabbath, etc.) 20.0

c. Music (congregational singing, special music, the choir, etc.)

d. Fellowship (church as a family, brotherhood, lunch at the park, etc.) . 6.6

e. Other (social activities, guest speakers and guests from other churches, working 


$$
\text { with children, the pastor, etc.) } 15.8
$$

2. Dallas
a. The message
37.1
b. Straight sermons
25.9
c. The services
18.0
d. Fellowship
11.2
e. Music
4.5
f. Other (hope, fulfillment of Bible
prophecies)
3.4

When asked what changes they felt should be introduced in the life of the church, respondents gave a wide range of answers concerning many aspects of church 1ife. Of these, the most frequently mentioned were activities that respondents felt should be discontinued and activities they felt should receive greater emphasis. These suggestions are summarized below under the two categories mentioned.

Activities or customs which the respondents felt should be discontinued are:

Houston

Percentage

a. Lack of reverence 41.7

b. Fund-gathering suppers 19.4

c. Inappropriate ways of talking about. money

d. Other (Sabbath school classes, worldly festivities, social meetings in inadequate places, formality, etc.) 
Dallas

Percentage

a. Lack of reverence

40.3

b. Aspects of the services (such as use of modern music, offerings at every service,

Sabbath school classes, youth meetings

from the pulpit, long sermons, Sabbath

school report, dramatizations at the

church, etc.)

36.2

c. Disobedience to standards

14.5

d. Wrong administrative procedures

10.0

Activities or customs of the church which the respondents

felt should receive greater emphasis are:

Houston

Percentage

a. More love, brotherhood, care, etc. 26.6

b. Social activities $\quad 23.0$

c. MV meeting improvement 18.6

d. Reverence 13.9

e. Other (communion service, more time for

Sabbath school lesson, missionary work, evangelism, more study of the Bible and

the Spirit of Prophecy, learn more about

Jesus, etc.) 13.6

Dallas

a. Evangelism 25.2

b. Youth activities 19.8

c. Fellowship 17.1 
Percentage

d. Social activities

14.5

e. Punctuality in starting services

5.3

f. Choir

3.9

The above information was given to the study groups to aid them in their deliberations and to help them discover the areas where changes could be introduced.

Special groups' responses. In order to isolate particular situations that needed to be faced, the respondents were divided, with the aid of a computer, into nine categories:

1. General (including the two churches)

2. Dallas

3. Houston

4. Female

5. Male

6. Former Catholics

7. Ages sixteen through twenty-five

8. Ages twenty-six through thirty

9. Those who sometimes were tempted to leave the church

Categories one to three have already been analyzed, at least in their essentials. Groups four to eight will be considered only briefly, permitting more attention to be given the ninth category, which, of course, is the key one.

Sex. Only 96.9 percent of the respondents gave information regarding their sex. The distribution of respondents' sex was different in the two churches. In Dallas, 50 percent of the respondents 
were males and 43.6 were females; in Houston, 34 percent were males and 53.8 percent were females.

The females reported being baptized younger than were the males. Forty-three percent of the females and 20.2 percent of the males were baptized before fifteen years of age. A large percentage (68.9 percent of females and 62.8 percent of males) reported having been baptized between fifteen and twenty-five years of age.

A comparison of attitudes of males and females shows more females reporting a vital relationship with the church than did males. They also reported more complete pre-baptismal instruction and less temptation to leave the church. Females also had the highest estimation of the effectiveness of the program of the church, but at the same time considered fellowship in the church as poor (the highest rate). In the rest of the evaluation no significant differences appeared between the females and the males.

Males indicated better attendance at Sabbath school and prayer meeting than did females, but less at the Sabbath worship hour. They reported lower pre-baptismal instruction and lower postbaptismal care. There are no other important differences apparent.

Age. A comparison was made between the 16-25-year-olds, and the 26-30-year-o1ds. In spite of the difference in years which comprised the two groups (a ten-year span compared to a five-year span), comparisons can be made since this study is dealing with percentages. Table 18 indicates that the respondents in the older age group perceived themselves as stronger spiritually than did the younger group. Two conclusions might be drawn from these figures: 
TABLE 18

COMPARISON OF ATTITUDES AND EVALUATION BETWEEN TWO AGE GROUPS: 16-25 AND 26-30 YEARS OLD

\begin{tabular}{|c|c|c|c|}
\hline \multirow{2}{*}{ Relationship or activity } & \multirow{2}{*}{ Degree } & \multicolumn{2}{|c|}{ Percentage } \\
\hline & & $16-25$ & $26-30$ \\
\hline Relationship with the church & Vital & 37.7 & 50.0 \\
\hline Attendance at Sabbath school & Excellent & 60.7 & 75.0 \\
\hline Attendance at Sabbath worship & Excellent & 75.4 & 82.5 \\
\hline Attendance at prayer meeting & Excellent & 18.0 & 22.5 \\
\hline $\begin{array}{l}\text { Received pre-baptismal } \\
\text { instruction }\end{array}$ & Complete & 34.4 & 52.5 \\
\hline Received post-baptismal care & Complete & 22.9 & 30.0 \\
\hline Activities of the church & $\begin{array}{l}\text { Major source } \\
\text { of } \\
\text { satisfaction }\end{array}$ & 22.9 & 42.5 \\
\hline Program of the church & $\begin{array}{l}\text { very } \\
\text { effective }\end{array}$ & 13.1 & 20.0 \\
\hline Fellowship & Good & 16.4 & 22.5 \\
\hline & Outstanding & 1.6 & 7.5 \\
\hline Care of visitors & Outstanding & 3.3 & 12.5 \\
\hline Affirmation of members & Outstanding & 14.7 & 20.0 \\
\hline Evaluation of worship services & Outstanding & 18.1 & 27.5 \\
\hline $\begin{array}{l}\text { Participation in outreach } \\
\quad \text { program }\end{array}$ & Very Active & 8.2 & 17.5 \\
\hline $\begin{array}{l}\text { Participation helps } \\
\text { spiritual1y }\end{array}$ & A great dea 1 & 22.9 & 42.5 \\
\hline
\end{tabular}


1. The 26-30-year-old group has a more positive attitude and could be of decisive help for the well being of the church. They have energy and are at the peak of their youthful capacity and energy, yet in some ways they are already stabilized.

2. Part of the group that was between sixteen and twentyfive years of age is still in the stage of adolescence when some rapid changes are taking place in their personality, sense of values, and attitudes. In the area of religion, according to Jones, "there is more a decrease in enthusiasm and in positive feelings for the church than an increase in antagonism against it. "1 Hurlock adds that "childhood concepts of religion are basically unrealistic, and the adolescent may become critical of his earlier beliefs." ${ }^{2}$ This attitude is normal and should be understood, not as apostasy, but as a dangerous period of the normal life, which has to be correctly. managed in order to succeed. The minister's responsibility for this group of people is enormous.

Catholic background. Of the total respondents, 54.4 percent of the women and 43.9 percent of the men reported a Roman Catholic background. The respondents of this group are mostly between the ages of twenty-one years and thirty years, and are the newest in the church (31.6 percent reported less than one year in the church, and 33.3 percent from two to five years in the church). In most instances they were brought to the church by friends $(28.1$

$1_{V}$. Tones, "Attitudes of College. Students and Their Changes: A 37-Year Study," Genetic Psychology Monograph No.81 (1970): 3-80.

${ }^{2}$ Elizabeth B. Hurlock, Developmental Psychology (New York: McGraw Hi11 Book Co., 1975), p. 189 . 
percent). This is the largest group brought in through evangelistic campaigns and the smallest group brought in through the influence of other family members. What impressed them most about the church was its message; and, this emphasis was more obvious with them (see p. 167) than with the other groups. Their evaluation of the worship services is higher than that of any other group. They also rated the quality of reverence of worship services very good. In the other aspects, nothing special is observed.

Those tempted to leave the church. The attitudes and opinions of those admitting that they have considered leaving the church are of special value to this study. They represent 23.6 percent of the respondents from Dallas and 30.8 percent from Houston, or 29.8 percent of the total sample. Of these, 42.9 percent are female and 57.1 percent are male. Nearly half, or 44.6 percent, are in the group that was baptized between the ages of sixteen and twenty years. In general, they have been in the church longer than any other group. of course, being in the church longer than others, they have had more contact with the church and more chances to be hurt.

Most of those in this group were brought to the church by relatives (69.6 percent, the highest percentage among the groups). They represent the lowest percentage ( 7.1 percent) brought in by friends. An important aspect of these results is the fact that they constitute the largest percentage of those who were impressed by the people of the church ( 14.3 percent). This could mean that they are people-centered, which makes them more sensitive to the attitudes of others toward them. They have the largest number of members of the 
family who are SDA (28.6 percent have more than eight Adventists in their families).

The evaluation of the church by this group is also meaning-

ful.

1. Their attendance at Sabbath school and Sabbath worship is the highest of the six groups. Attendance at the prayer meeting is exceeded only by former Catholics.

2. Satisfaction with post-baptismal care is also the highest of any of the groups.

3. With respect to participation in the outreach program, they rated themselves as being very active (second after the group of 26-30-year-olds).

There are, however, several areas which this group evaluates as low. They have the highest percentage in affirming that:

1. The activities of the church are burdensome

2. Unity among members is poor

3. Fellowship in the church is poor

4. Care for visitors is poor

5. Affirmation of members is poor

6. Worship services are routine

7. Reverence at the church is poor

8. Preaching is routine

9. Financial demands are excessive

10. People leave the church because of problems with other nembers. 
The frequency of factors influencing their consideration of possible withdrawal from the church are summarized below:

1. Houston (seventeen reasons cited)

No. of reasons

a. Problems with the church 12

b. Problems of the individual 5

2. Dallas (thirty-eight reasons cited)

a. Problems with fellow members

b. Family problems (persecution, marriage with unbelievers, divorce, etc.)

c. Personal problems

d. Standards of the church decaying

e. Other

\section{Step 4: Study Groups}

The last step of the process of self-assessment, and at the same time the first step in the goal-setting stage, is the work of the study groups. Implementation of goals should follow naturally.

The data are now carefully studied to isolate areas which deserve deeper study and in which some corrective measures should be taken. In the particular cases of Dallas and Houston, some of the nine main topics suggested previously, ${ }^{1}$ were selected because they seemed to fit the local needs.

$1_{\text {See pp. 62-63 above. }}$ 
were selected, because they seemed to fit the local needs. Preliminary organization

In Dallas six study groups were organized to deal with the following topics:

1. Fellowship in the church

2. Spirit of worship and adoration

3. Preaching

4. Outreach program

5. Mid-week prayer meeting

6. The church and money

The leaders of each group--selected and trained beforehand-received two helpful items: (1) a summary of the findings of the three previous steps in the area to be studied, and (b) an outline to be used eventually as a guideline for the discussion. (See appendix B).

The outline was divided into three sections:

Diagnosis. This consisted of questions to be answered in order to sense and evaluate the present condition of the church in that particular area of concern, and to give a beginning point for the discussion, avoiding useless preparation (especially considering the short amount of time available for the discussion). The summary of the result of the previous self-assessment was used in this stage of the work.

Possible solutions. These sets of questions were designed to ask for practical and attainable solutions for the shortcomings of the congregations. Some of the groups followed the sequence in an 
organized way, presenting a fairly well-organized report as a result of their discussions.

Practica1 suggestions. It was suggested that each group endeavor to maintain a balance between the time devoted to the diagnosis and to the search for solutions. While adequate time was needed for the former, sufficient time must be reserved for the most important part, namely, the search for solutions. The diagnostic process would set the framework for developing remedies.

The actual report of the groups shows that this plan worked we11. Quite a large number of practical suggestions were presented. Selection of leaders

In counsel with the pastor of the respective churches and the members of the team, the list of group leaders and assistants was prepared. Each leader was assigned one topic, according to his own preference.

Members of the groups

The choice of the group in which to participate was left in the hands of every member present. Full information about topics, place, and leader was given and everyone was free to participate in the group of his or her election.

In both churches the results were quite satisfactory. However, Dallas had the advantage of larger and more comfortable rooms in which to meet. The average attendance in Dallas is shown in table 19.

The preference for attendance at a particular group could be interpreted in different ways: 
TABLE 19

ATTENDANCE AT THE STUDY GROUPS IN DALLAS

\begin{tabular}{cc}
\hline Group No. & $\begin{array}{c}\text { Average } \\
\text { attendance }\end{array}$ \\
\hline 1 & 32 \\
2 & $*$ \\
3 & 24 \\
5 & 16 \\
6 & 9 \\
\hline
\end{tabular}

*The entire congregation studied topic 2.

1. Location of the meeting place, which would justify the larger attendance in groups 1 (main sanctuary) and 3 (balcony)

2. Interest in the topic to be analyzed

3. Attraction to the leader in charge of the group

The author does not attribute much importance to the factors involved in " 1 " and " 3 " above as being the primary motivating influences. He believes that the topics to be analyzed were the main attraction, and considers it as another symptom of the awareness of needs on the part of the congregation.

The main concern of the congregation was doubtless the quality of the environment and the need for spiritual nurture through preaching. The probable reason for the sma11 number gathered to study the prayer meeting (group 5) was that that particular activity 
is a difficult one in a working day in a large city. If the meeting is not conducted with special dedication, it would not be worth the sacrifice required to attend. Presumably it is not perceived to be an attractive meeting by a majority of members.

\section{Time available}

The daily program lasted approximately one hour and ten minutes. The study groups had only thirty to forty minutes for their discussion. The program every evening was scheduled as follows :

$\begin{array}{ll}7: 30 \quad \text { Welcome and opening song } \\ & \text { Scripture reading } \\ & \text { Prayer } \\ & \text { Short inspirational message } \\ & \text { Division into groups } \\ 7: 45 \quad & \text { Return to the sanctuary } \\ 8: 30 & \text { Prayer groups } \\ & \text { Closing song } \\ 8: 40 \quad \text { Dismissal }\end{array}$

The time allotted in this program proved to be somewhat short. At least one and ahalf hours should be allowed, for the evening sessions in order to have at least one full hour for the study groups.

\section{Reports}

The reports of the suggestions of every group began to be presented to the congregation on. Thursday evening, as a means to prepare the way for the final report presentation at a special mecting to be held on Sabbath afternoon. The study of the reports will be made in chapter VI. 


\section{CHAPTER VI}

\section{INTENTIONALITY IN THE LIFE OF THE CONGREGATION}

The objective of chapter VI is to analyze the work done by the study groups in Dallas and Houston, and to evaluate the suggestions given.

The first three steps have provided a large amount of information about the present reality of the congregation. The fourth step adds a new dimension to the whole process: it is not only an assessment but the search for ways to improve the life of the congregation, the setting of goals and the introduction of changes as deemed necessary with the final objective of enabling the church to nurture its members, thus avoiding dropouts.

\section{Need of Intentionality}

The self-assessment program presented in chapter $V$ had a twofold objective:

1. To honestly assess the present reality of the life of the congregation, comparing it with the ideal to be reached.

2. To give intentionality to what the congregation is and does in order to improve, by making the necessary changes.

A basic characteristic of a successful congregation is a clear sense of mission with clear goals and objectives. Some 
congregations are "trapped in unproductive ways of living," 1 which cause them to die. Mead affirms also that "it is possible to make significant headway against the barriers of freedom that get built into our parish life. That which is unrewarding and depressing in congregational life can be changed. There are directions to go and ways to get started." 2

A healthy congregation must be acting, moving, and growing. Action, movement, and growth, however, are not in themselves enough. Activity is not necessarily synonymous with effectiveness. ${ }^{3}$ Movement is not necessarily synonymous with progress. Movement in a wrong direction is unhealthy. There is positive growth, but there can also be negative growth. Cancer is a growth, but it kills.

The complete cycle to be followed by a healthy organization includes the following steps: the clarification of purposes and objectives, awareness of needs, establishing goals, planning, action and evaluation. (See figure 8.)

The purpose 4 of intentionality is to achieve renewal aimed at the reaching of the ideal set by God for His church. This renewal includes changing what needs to be changed in the life of the congregation. The process of self-assessment in its first three steps is designed to produce an awareness of the needs and shortcomings

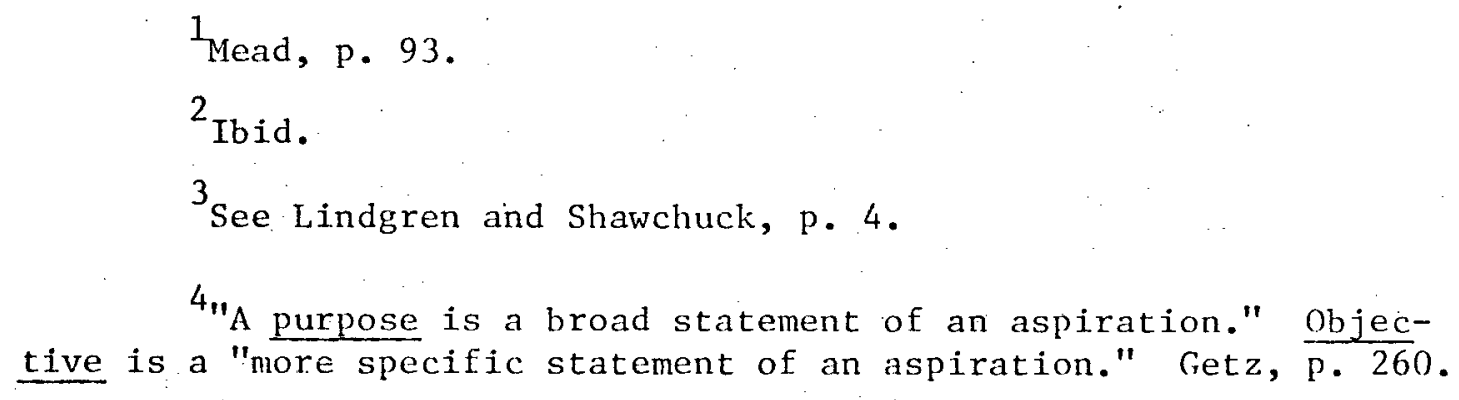
tive is a "more specific statement of an aspiration." Getz, p. 260 . 


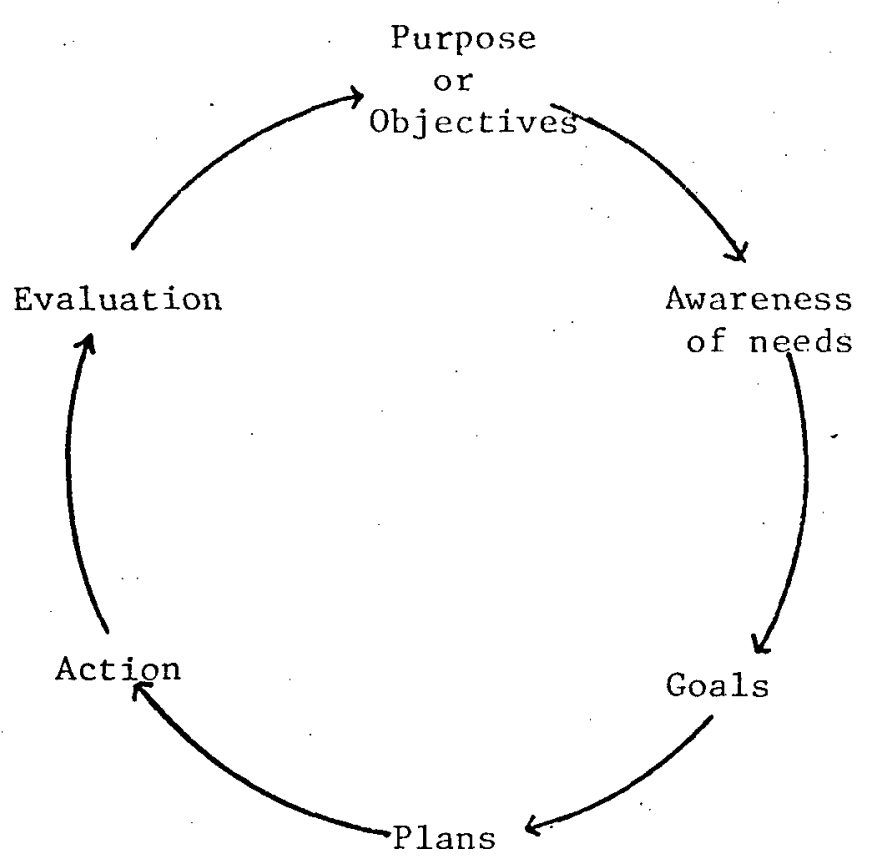

Fig. 8. The continuous cycle that gives intentionality to the life of the church.

within the congregation and thus reveal areas in need of change or improvement. The fourth step, the study groups, concludes the analysis of needs and includes setting goals ${ }^{1}$ to address those needs and achieve congregational purpose.

At this stage of the cycle the church faces a decisive issue. The data are now available; what the data say may be accepted, rejected, or simply ignored. The latter is perhaps the easiest way to move. Enge1 says: "Either [the church] takes these data seriously and seeks the mind of the Lord in discovering the changes $\mathrm{He}$ wants, or it perpetuates the effectiveness crisis by taking no

1"The goal is a still more specific statement of what is to be accomplished to produce progress toward an objective." Ibid. 
action whatever." 1 When the self-assessment stage of the process is finished, the church takes an important step forward. However, this step without further planning and action would not only be fruitless, but it would be harmful. It will deepen doubts, resentments, and frustrations unless serious measures are taken to change the situation and search for a change. The weaknesses of the congregation will be more evident now, because they have been made public.

The study groups now sought to identify areas of need in which action might be taken toward change. The suggestions which emerged from the study groups could not at this stage be described, technically speaking, as "goals" ${ }^{2}$ but these suggestions would lay the groundwork for more concrete proposals later.

\section{Analysis of the Reports}

In order to show the kind of work that such groups can do, the report of group 1 of Dallas is reproduced in full in the following pages. The reports of the other groups will then be briefly reviewed and are included in full in appendix D.

\section{Report of Group 1--Dallas}

WHEREAS the survey developed among members revealied the need to strengthen the spirit of fellowship with the congregation, the following measures were suggested:

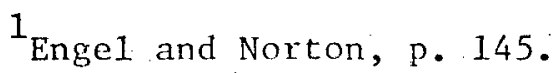

2 A statement such as "to create a spirit of fellowship". is too general but has value in identifying potential points of focus. 
1. How Better to Care for Visitors:

a. to identify visitors with a badge

b. to lead visitors to a comfortable place in the sanctuary

c. to request somebody to sit beside visitors to help in case of need, such as to share a Bible and a hymna1

d. to start a campaign in the church to interest members in the well-being of visitors, caring for them

e. to keep a record of visitors, reading their names and introducing them to the congregation

2. How Better to Care for Sick People:

a. to form a committee whose task would be to keep careful track of any possible sick person in the congregation

b. to visit sick members as soon as possible after learning that they are ill

c. if the sick person is unable to come to the communion service, to take him/her the emblems to allow him/her to participate

d. to create a fund to send flowers or get-well cards to sick members

3. How to Help the Discouraged Members:

a. to visit and try to encourage them 
b. to send discouraged members a card when they are missed at the services

c. to form special prayer bands asking God for their recovery

d. to try to find ways to help them in solving their problems

4. How to Help Those Facing Financial Problems:

a. to visit the person in order to be better acquainted with the real situation

b. to take the necessary steps to help in solving the problem, avoiding a desperate situation

5. How to Help Young People:

a. to organize more recreational activities

b. to avoid destructive criticism of young people, trying by all means to understand them and their problems

c. to try to win their friendship and trust (confidence)

d. To organize more activities involving young people on Sabbath afternoons, in coordination with the missionary department of the church

e. to improve support, without discrimination of the music directors, and unite them in the goal of forming a church choir

f. to take advantage of the talents and spiritual gifts of the young people, providing them with 
opportunities to participate in the services

g. to provide special stimuli, such as the election of the "youth of the month"

h. to allow young people to participate in special trips or engage in special activities under the direction of an appointed leader, taking advantage of special dates or events

i. to search for means to reconcile young people among themselves in case of interpersonal conflicts

6. How to Help Children:

a. to fix and equip the children's Sabbath school rooms

7. How to Help the New Members:

a. to provide prospective members with a better prebaptismal preparation

b. to organize a fellowship dinner after baptism as a special welcome to new members, inviting the newcomers by profession of faith and transfer as well

c. to invite them to visit in our homes

d. to provide them with special post-baptismal care

8. How to Foster Friendship and Fellowship among Members:

a. to have Christ in our hearts

b. to pray in order to overcome any spirit of criticism

c. to avoid the establishing of differences among menbers, cultivating fellowship with all without forming c1iques 
9. What Could Be Done to Avoid Conflicts:

a. to have meetings such as this more often

b. to approach the person with whom we have the problem, or to see the pastor or another reliable person asking him to intervene between persons in conflict

c. to carry out weeks of prayer more frequently, since the last one was conducted more than three years ago

10. Additional Suggestions Given by the Audience:

(When the present report was presented to the whole congregation, a lively discussion took place. Some additional suggestions were presented and accepted by the audience.)

a. to prepare and print an up-to-date directory of the church, including the names, addresses, and telephone number of all the members, making copies available to the entire church

b. to help the non-Spanish-speaking visitors through a translator, preferably in the balcony.

c. to replace the sign outside the church with a sign written in Spanish

d. to provide the church members with a calendar with sunset time in the area for the whole year

Analysis of the report of group 1--Dallas

Witnessing the way the discussion was conducted, it was evident to the researcher that the leader of this group had a clear idea of the topic he himself had chosen to discuss. As a member of 
the church, he himself was an example of good human relations and fellowship toward the other members of the church and appeared to enjoy their general appreciation. The guidelines provided (appendix B) were well used by the group. It was also clear that the leader was trying to cover the whole agenda.

A few of the suggestions given are quite broad, such as "to have Christ in our hearts" ( see 8-a), or "try to win their [young people's] friendship and confidence" (see 5-c). Others are perhaps a repetition of what is well known, such as "to provide them [new members] with special post-baptismal care" (see 7-d). All these may better be labeled as "purpose" rather than "goals," 1 or at least as "non-measurable goals."

Some ideas are clear and could be considered measurable goals, such as "to identify visitors with a badge" (see 1-a), or "to keep a record of visitors, reading their names and introducing them to the congregation" (see 1-e). It is easy to measure whether or not these goals are being reached or not.

Other suggestions merely give the idea, leaving the development and implementation to the church board (see 5-a, 5-c, 5-d, 7-a) or to the individual members (see $8-a, 8-b, 8-c$ ).

\section{Reports of Groups 2-6--Da11as}

A Brief Analysis

In order to notice the possibilities for improvement afforded by this consultation with the members of the church, general

1"The difference between a goal and a purpose is that a goal is measurable." Engstron and Dayton, p. 19. 
comments about the report of other groups at the church in Dallas are made here. (See the full reports in Appendix D.)

Report 2--Worship and adoration

The study of this topic--the spirit of worship and adoration-was made by the whole congregation. The recommendations are solutions for real situations lived by the congregation, especially in what relates to point two of the report (Preparation of the service).

According to information received, there were long delays in beginning some services and between the Sabbath school and the worship service. Improvisation seemed to be the characteristic of the leadership of worship. This same criticism was apparent in the report of group 3 .

Lack of reverence appears to be a rather common characteristic in Latin-American churches. However, the Dallas members were concerned with the problem. A determination to reduce extraneous movement and noise to a healthy minimum was expressed.

The report includes good suggestions which might well occupy the congregation and the board in the work of producing healthy change. Report 3--Preaching

The initial report had to be softened somewhat in order to keep it within previously agreed-upon rules pertaining to the work of the study groups. Members were concerned about some aspects of the preaching segment of worship. These were discussed one by one:

1. Lack of enough time for the sermon, especially on Sabbath mornings, caused by the long announcements, unnecessary intervals, delays in beginning the service. 
2. Priority given to the presentation of the children's story to the detriment of the sermon. Sometimes the story would be given more time that the sermon itself.

3. Use of the pulpit--especially by laymen--to deal with interpersonal conflicts, or to make personal references to specific problems in a subjective manner.

The search for solutions to these problems led the group to what some saw as extreme suggestions such as the elimination of the children's story and lay preaching--the latter reserved only for emergency situations. During a discussion of the matter of adequate time for the sermon, it was made clear by the members that the elimination of the children's story was not the best solution for the problem. The solution was, rather, a well-prepared and wellorganized service, conducted according to a schedule. It was indicated that time could be saved in many other ways without sacrificing the attention to the needs of the children.

During the floor discussion an observation was made regarding the danger implied in the approval of point seven of the report (eliminating lay preachers except in emergencies)。Appreciation was expressed to those who perform acceptably as lay preachers. The need of prepared lay preachers was emphasized, their role elevated, and a plea was made for the organization of training classes to prepare them to preach, not only in the church, but to conduct evangelistic meetings as well.

Point 4 of the report (types of sermons) was motivated by the issue presented under " 3 " above. The objective of the original 
suggestion was to avoid the wrong use of the pulpit. The second part of the paragraph was included during the discussion for the purpose of discouraging the idea that preaching should be aimed only at pleasing the congregation. In the course of the discussion it was concluded that the congregation might expect rebuke and even reprimands from the preacher, but in no case should preaching be used as an instrument of revenge.

As in the case of group 2, this group made several kinds of suggestions, some of which were general, some specific, and some perhaps unnecessary. Their implementation, however, would presumably create a healthier atmosphere in the services, especially on Sabbath morning.

Report 4--Outreach program

Considering the specific situation of the missionary activities of the church, points 2 and 3. (participation and training respectively) are possibly the most important. The reasons checked why some people (while aware of the importance of participating in the outreach program of the church) do not participate are: (1) lack of enjoyment in doing something not according to their taste, abilities, or spiritual gifts, and (2) the lack of appropriate training. The discovery of each individul's gift, the assignment of a task according to that gift, and the practical training while participating in the task with someone else who has experience and ability will help in the achievement of the other goals presented in the report. Report 5--Prayer meeting

The two main goals of the group were, according to the report, 
to increase attendance and the participation of worshippers through sharing. Two of the points in the first area (to increase attendance) are too general. There is no explanation of what is meant by "spiritual" and "interesting." The first four points in the second area (participation) are implicit definitions of what the group considered to be a spiritual and interesting worship service. Participation at services with such a variety of participation would certainly be more interesting than to follow the routine in which the average mid-week services is conducted.

The inclusion of a day dedicated to visitors (see 2-f) from time to time was an expression of concern for outreach through the mid-week service. The same could be said about "2-g" (an occasional musical program). This group was led by a veteran minister who, although having devoted his whole ministry to administrative tasks, has shown pastoral interest in his work as a local elder after retirement. His leadership is clearly visible through the report presented.

A revival in such an important service as the mid-week prayer meeting could help bring spiritual power to the congregation and could be a key element in the renewal of the congregation. Report 6--The church and money

A very good spirit was demonstrated by the members of this group in dealing with a rather difficult subject. The larger portion of the congregation, as shown through the survey, seemed to have a positive approach to the financiat requirements of the church. There were, however, approximately 10 percent of the respondents who 
considered the demands excessive. The comments were that the amount of money requested is not excessive, but the requests are too frequent, thus giving the idea that the amounts requested were too high.

The group faced that situation and brought out some practical ideas aimed at the reduction of the number of offerings and the spiritualization of every offering announcement or campaign carried out at the church. The reaction of the congregation was very positive.

\section{Report of Group 2--Houston}

The reports presented by al1 the groups that met in Houston will not be analyzed here. What was done by group 2, however, will be considered in order to comment on the possible ways to deal with the suggestions in transforming them into measurable goals. Text of Report 2--Worship and adoration

"WHEREAS, both the quality of the service and the worshippers' attitudes while worshipping are important ingredients for an inspiring experience of adoration, it was recommended:

1. That both the preacher and the congregation be united in the purpose of achieving the necessary reverence during the services to this end:

a. The preacher should always present messages that captivate the interest and attention of the 1isteners, instructing and inspiring them with the word of cod.

b. The preacher should teach reverence through his own example 
c. The congregation should follow attentively the development of the sermon, taking notes of what is said for later study

2. That a campaign aimed at fostering reverence be initiated to create the consciousness that God is present, according to His promise, transforming the meeting place into a holy place.

a. That all music, either played or sung, be well prepared and of high quality

b. That the congregation be urged to participate joyfully in the singing

c. That leadership of worship be carefully prepared, avoiding any kind of improvisation

d. That every service be opened and closed at the appointed time

e. That everybody be encouraged to arrive on time, to receive the blessings of the worship hour from the very beginning

f. That after the closing of the service, the congregation leave the place in order

g. That improper habits of children be avoided, such as unnecessary movements in and out of the sanctuary, eating, playing with noisy toys, key rings, etc. during the service

3. As an additional help to the spirit of adoration, it was suggested:

a. That the building be cleaned regularly and that a 
campaign be initiated to maintain it

b. That the air conditioning or the heating system be kept under control during the whole service to create a pleasant physical atmosphere

c. That for the same reason, proper care be taken of the public address system, in order to provide good sound in both the sanctuary and the mothers' room

d. That at least fifteen minutes before the beginning of every service, soft preparatory music be played, either recorded or at the piano, organ, or marimba

e. That study be given to the possibility of installing cushions on the pews to make them more comfortable

f. That the tithe receipts not be filled out during the time of worship

g. That study be given to the relocation of the telephone to avoid disturbances during the services

h. That a positive disposition toward those charged to lead the campaign for reverence be promoted

\section{Implementing the Suggestions}

According to our model, once the reports are presented, the congregations have the responsibility of implementing what has been suggested. The reponsibility for implementation lies with (1) the pastor, (b) the church board, and (3) the individual members. $\Lambda 11$ must assume their responsibilities. In this situation the church is asking the pastor to take certain responsibilities, and he should be aware of what is expected of him. Some decisions must be made 
by the board, such as appointing someone to lead out in the concern for reverence in worship. Finally, the ultimate success or failure will rest upon the individual member without whom this or any campaign would be fruitless.

Setting of priorities

A campaign to implement all suggestions might be initiated simultaneously. Perhaps this would be the best approach in order to create an impact. However, it may be wiser to set a schedule for the implementation of the different ideas in a progressive way. Each church must determine its own priorities and select its own strategies for the implementation of suggested programs.

The church at Houston began with the strengthening of the prayer meeting as a way to bring power to the whole church, starting from the nurturing root of renewal--God and His power. A series of studies on spiritual gifts was also launched, stimulating a great deal of interest among the members. As a result of the discovery of their gifts, the suggestions given in regard to the outreach program might be easier to carry out.

Suggestions transformed into goals

It is easy to suggest ideas, such as "to start a campaign for reverence." This, of course is not, technically speaking, a goal. The church board may transform that general objective into an operational goal. ${ }^{1}$ The following are samples of what the board might, with proper briefing, decide upon:

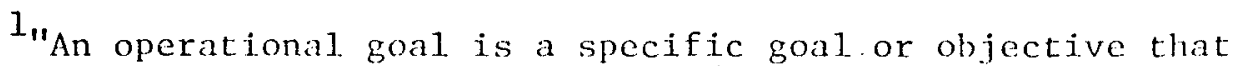
defines a particular target in precise terms, is feasible in terms of
} 
1. To designate somebody as the leader of the campaign, assigning him with specific responsibilities, such as:

a. organizing the services well ahead of time in order to avoid delays or improvisations. A meeting with the Sabbath school. superintendent, the MV leader and the pastor will help to achieve this goal. The date and place for the meeting is set immediately.

b. using a few minutes every Sabbath morning to share some practical ideas about the way to foster worship in a spiritual way. This would include what should be done at home before coming and a preparation for the service, what to do when arriving at the sanctuary, while waiting, etc. The meaning of worship should be explained, not confusing lifelessness or sadness with adoration.

c. improving the facilities of the mothers' room, thus to encourage its use

d. having special time in the children's departments to instruct them in reverence and worship

e. designating someone as directly responsible for the control of the heating and air-conditioning systems

3. Designating someone to be in charge of the public address system, and to be responsible for the special music to be played as a preparation for the services

available resources, can be related to a timeline or schedule, includes mileposts for measuring progress and has built into the definition the criteria for subsequent evaluation." Lyle E. Schaller, "Use Operational Coals," Church Administration 14 (June 1972), p. 19. 
4. Arrange for the relocation of the telephone Planning and acting

Articulating operational goals is the first step in the planning process. ${ }^{1}$ other decisions have to be made, such as allocating funds to finance some of the activities to be carried out or the setting of a schedule with deadlines to be reached.

\section{Evaluation}

Periodical evaluation is necessary to measure the degree of progress and direction. The entire program is directed toward a purpose or objective. When this objective is reached the work has not yet been concluded because of the human tendency to go back to old patterns. The process must be repeated. As in nature, winter is followed by spring, and the fruitful season of summer is followed by autumn, so in the church, renewal is not a permanent experience but one in continual renewal.

${ }^{1}$ See fig. 8, p. 111. 
CHAPTER VIT

SUMMARY AND CONCLUSIONS

\section{Summary}

The church is a distinctive entity. It has a divine origin but is composed and led by human beings. It is in the world, but is not of the world. Since the very mission of the church implies an interaction with the world, this distinction is not always a reality. Consciously or unconsciously the church eventually becomes contaminated with the norms and practices of the world, losing in a smaller or larger degree its distinctiveness, sometimes becoming similar to a worldly organization. When this happens, its spiritual impact is diminished; there is a decrease in accessions and an increase in dropouts, producing stagnation or even decrease.

If this is the case, the obvious remedy is some sort of revitalization, reformation, or renewal to bring the church back to its ideal. The very nature of this experience, the ways to achieve it, and the fruits expected, are issues that have received different kinds of answers.

The Program Proposed

The objective of this project has been to present a possible tool to lead the church into a renewal experience through a reformation of the quality of internal climate and environment. 
The process included a self-assessment program through which the congregation is looked at from different angles: (1) the individual member evaluates the quality of his relationship with God, the church, the family, and the community; (b) former and inactive members are interviewed to ask their advice in the search for improvement in the life of the congregation; (c) a survey is conducted among current members to make a profile of the needs of the church from different angles.

The church is then divided into small study groups to analyze the data collected and identify its actual needs, bringing suggestions which, transformed into goals, would give intentionality to what the church is and does.

All this process would prepare the congregation for the operation of God's power, the only one able to breathe life into dry bones. Renewal is a work performed by God when the church is prepared for that operation.

\section{The Field Test}

The above-mentioned program was carried out as a test in two Spanish-speaking congregations in Texas--the Oak Cliff Church in Dallas and the Robertson Street Church in Houston, during January and February, 1980. The results of the Personal Analysis and of the Survey among members ${ }^{1}$ were tabulated and studied with the objective of drawing some conclusions to be used as the basis for a

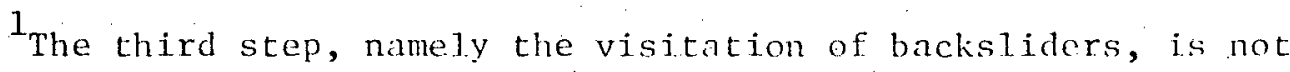
included in this report due to the linited number of persons to be visited in the area. 
goal-setting program. The congregations were then divided into study groups to analyze the results of the previous steps and develop suggestions to be presented to the congregation and the church board aimed at the search for a renewal experience through change.

The reports were presented, discussed, and actions were taken in regard to their implementation. The churches then began a campaign to improve the aspects of their lives in need of improvement.

The study conducted as a field test appears to confirm the thesis that the main cause for dropouts is to be found, not in theological disagreement, but in the quality of the climate of the church. A vast 1iterature on the growth of cults, especially those of Oriental origin, shows that their attraction resides in the fellowship and care for the individual which they offer, which spirit is somewhat absent from some churches, mainly those which are declining.

\section{Conclusions}

On the basis of this research summarized above, the following conclusions are set forth:

1. There is concern among the members of the churches about the existence of unsolved problems in the life of the congregations, every one of which may be different.

2. Sometimes these situations are clearly identified. In some cases they are faced and solved. In other instances the situations are identified but not faced, producing hurts that are potential causes for dropouts or uneasiness.

3. In other cases, the situation is felt but not identified, 
and consequently neither faced nor solved.

4. Members of most of the churches are eager to cooperate in improving the life of the congregations. What they need is motivation to act.

5. A vital element in this process of improvement is the freedom provided by leaders openly to discuss the issues involved in the improvement of the congregational life.

6. A pastor who humbly and sincerely seeks for advice from his congregation will be rewarded by the unconditional support of the human element whose attitude toward him and his program may well signify his success or failure. Although the position of the pastor as leader might sometimes become uncomfortable during the discussion, his positive attitude will help him in the fulfillment of the whole program.

7. Members show a deeper concern and desire for changes in the areas of human relations and worship, longing for a deeper communion between leaders and members and with God. In the latter, preaching plays a very important role.

8. Renewal is a divine but a human task. The function of the leader should be to motivate the congregation to reassess its condition and be prepared for the operation of God's power. The prophets in the past presented continuous calls for change in the life style of God's people. Through Isaiah God said: "Wash you, make you clean; put away the evil of your doings from before mine eyes; cease to do evil; learn to do well; seek judgment, relieve the oppressed, judge the fatherless, plead for the widow" (Isa $1: 16,17$ ). 
When there is the disposition to do it God produces the cleansing. "Come now, and let us reason together, saith the Lord: though your sins be as scarlet, they shall be as white as snow" (v. 18).

The messages to the seven churches of Revelation are based on calls to repent, to do the "first works" (Rev 1:5), to "overcome" $(\operatorname{Rev} 2: 7,11,17,26 ; 3: 5,12,21)$, and to keep God's word (Rev 2:26). Al1 these are followed by promises of forgiveness, salvation, and cleansing. Men's disposition is followed by the operation of God's power. 1

\section{Solutions}

After listening to the discussions in Dallas and Houston, and after reading the responses to the survey, the proposed solutions could be reduced to one: the improvement of the quality of the internal climate of the church through a twofold process:

(1) discovery of the true actual situation, searching for identification of the weak areas, and (2) a dedicated effort to face the shortcomings and a sincere search made for improvement.

When the quality of worship is improved, worshippers will experience the power of communion with God; when the quality of preaching is improved, listeners will be nourished by the Word of God and not by more or less capable lecturers; when the spirit of fellowship is improved, members will feel that there is no other place in the world like their church, and they will not desire to leave it. The manifestation of true Christian love would

${ }^{1}$ See Tippett, pp. $67-69$. 
demonstrate: the authenticity of the message preached by the congregation. What the church does is important. Most important, however, is what the church is.

Application of the program

The program suggested in this study is intended to be a help to a local pastor in facilitating change and renewal--especially in the preparation of a congregation for an evangelistic thrust. The following suggestions are based on what was learned to date in its application:

1. The pastor himself can conduct the program in his own church or may obtain the help of a consultant. There are advantages and disadvantages in both cases. The pastor will be able to follow the implementation of the goals proposed, while the consultant will remain only for part of the program. However, the consultant will be able to act with more freedom than the pastor because of his noninvolvement in local situations. The approach to be used will be determined in every case by the needs, character, and possibilities of the congregation.

2. A packet of materials for the use of pastors and lay persons could be provided by the local conference, including guidelines and instruments for the entire program.

3. Lessons drawn from the experience in Texas:

a. It is inadvisable to conduct this program without the full support and presence of the local pastor. The experience of Dallas would probably have been even more fruitful had the pastor been present. The success of the program depends on the willingness 
of the pastor to achieve with his congregation the experience of renewal. His identification with the entire process is vital for the overall results.

b. More time should be devoted every evening to the study groups. In both cases--Dallas and Houston--the period of time was too short for thoughtful work. An hour, or even an hour and a half, should be devoted every evening to the study of the different topics.

c. More evenings could be devoted to the study groups. At least four evening sessions are needed for a relaxed discussion.

d. The groups should not analyze too many points, but rather, reduce the discussion to the most important issues according to the local situation.

e. By increasing the daily period and the number of sessions, the study groups could not only prepare a set of suggestions (as in Dallas and Houston), but also elaborate upon them, formulate operational goals, and establish priorities and schedules. Another alternative would be to extend the period of the self-study for a longer time, meeting weekly, to search for means of implementing the suggestions presented during the initial stages.

f. The work of the consultant should be extended at least until the suggestions are framed into operational goals, the priorities set, and the schedules prepared. The field tests conducted in Texas were limited only to the self-assessment program which was found to be a good experience, but not as complete as it should be. 
For Further Study

Due to the limitations established for this project, some other areas of interest are not included which deserve further study. The following topics might well be studied:

1. The effects of intentionality on other areas of the life of the congregation, such as structures, styles of leadership or administration, budget, etc., in the overall success of the fulfillment of the mission of the church.

2. The organization of a campaign to recover former members after the church has been prepared to receive and properly nurture them. 
APPENDIX A

THE INSTRUMENTS 
Form 1

PERSONAL ANALYSTS

There are three standards by which you are eviluated:

1. What you believe you are

2. What others believe you are

3. What God believes you are

There is always a possibility of error in the first two; only the third is infallible. An honest self-analysis would help in finding areas in which your personal experience is weak and where it is strong. You can evaluate yourself by circling the number which you estimate represents in a scale $0-5$ your present condition in each one of the fourteen items listed below:

1. My prayer life

2. My devotional readings

3. My faith

4. Ny church attendance

5. My trust in the church

6. My stewardship

7. My witnessing

8. My willingness to serve

9. My family devotions

10. I and my wife/husband

11. I and my children

12. I and my parents

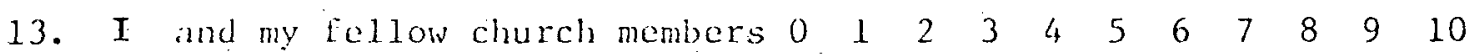

14. I and my neiphbors

Poor Optimum

$\begin{array}{lllllllllll}0 & 1 & 2 & 3 & 4 & 5 & 6 & 7 & 8 & 9 & 10 \\ 0 & 1 & 2 & 3 & 4 & 5 & 6 & 7 & 8 & 9 & 10 \\ 0 & 1 & 2 & 3 & 4 & 5 & 6 & 7 & 8 & 9 & 10 \\ 0 & 1 & 2 & 3 & 4 & 5 & 6 & 7 & 8 & 9 & 10 \\ 0 & 1 & 2 & 3 & 4 & 5 & 6 & 7 & 8 & 9 & 10 \\ 0 & 1 & 2 & 3 & 4 & 5 & 6 & 7 & 8 & 9 & 10 \\ 0 & 1 & 2 & 3 & 4 & 5 & 6 & 7 & 8 & 9 & 10 \\ 0 & 1 & 2 & 3 & 4 & 5 & 6 & 7 & 8 & 9 & 10 \\ 0 & 1 & 2 & 3 & 4 & 5 & 6 & 7 & 8 & 9 & 10 \\ 0 & 1 & 2 & 3 & 4 & 5 & 6 & 7 & 8 & 9 & 10 \\ 0 & 1 & 2 & 3 & 4 & 5 & 6 & 7 & 8 & 9 & 10 \\ 0 & 1 & 2 & 3 & 4 & 5 & 6 & 7 & 8 & 9 & 10 \\ 0 & 1 & 2 & 3 & 4 & 5 & 6 & 7 & 8 & 9 & 10 \\ 0 & 1 & 2 & 3 & 4 & 5 & 6 & 7 & 8 & 9 & 10\end{array}$

Are there any areasi in which rou need to improve? TE the dianosis; is low, do not despalir. Jestls offers llis love, power, and vicecry. "Apite from me you can de mothing" (John 15:5). "be of nood cheer, T have avercente the world" (John 16:33). "Lo, I am with you alway" (Male 28:20). 
MY CONCREGATION

Survey among Members

(No signature needed)

I. General Information

$\begin{array}{lll}\text { 1. [ ] male [ ] female; [ ] single [ ] divorced } & \text { [ ] married [ ] widowed }\end{array}$

2. Present age: [ ] $11-15$ [ ] 36-40 [ ] 61-65

[ ] $16-20$ [ ] $41-45$ [ ] $66-70$

[ ] $21-25$ [ ] $46-50$ [ ] $71-75$

[ ] 26-30 [ ] 51-55 [ ] 76-80

[ ] [ ] $31-35$ [ 56-60 [ ] 81 or older

3. Age when baptized:
[ ] 10 or under [ ] 26-30
[ ] $11-15$
[ ] $31-35$
[ ] 46-50
[ ] $66-70$
[ ] $16-20$
[ ] 36-40
[ ] $51-54$
[ ] $71-75$
[ ] $21-24$
[] $41-45$
[ ] $55-60$
[ ] $61-65$
[ ] 76-80
[ ] 81 or older

4. How long have you been a member of the church?
[ ] less than a year
[ ] 21-25 years
[ ] 46-50 years
[ ] 1-5 years
[ ] 26-30 years
[] 51-55 years
[ ] 6-10 years
[ ] 31-35 years
[ ] 56-60 years
[ ] $11-15$ years
[ ] 36-40 years
[] 61-65 years
[ ] 16-20 years
[ ] 41-45 years
[ ] 66 or more years

5. How far from the church do you live?
In miles:
[ ] $1-5$
[ ] 6-10
[ ] $11-15$
[ ] $16-20$
In time:
[ ] $15 \mathrm{~min}$.
[ ] $30 \mathrm{~min}$.
[ ] $45 \mathrm{~min}$.
[ ] 1 hour
[ ] $1 \mathrm{hr} .15 \mathrm{~min}$.
[] more
[ ] more

6. How many other members of your family are in our congregation? (circle one)
$\begin{array}{llllllll}0 & 1 & 2 & 3 & 4 & 5 & 6 & 7\end{array}$
89
$\begin{array}{llllll}10 & 11 & 12 & 13 & 14 & \text { more }\end{array}$

7. Have you ever been a member of another SDA church? [ ] yes [ ] no

8. Have you been a member of another denomination?

[ ] yes [ ] no Which one?

9. How did you get acquainted with the SDA church?
[. ] family
[ ] 1iterature
[ ] radio/TV
[ ] friends
[ ] evangelistic campaign
[ ] Other (state)
[ ] school.
[ ] lay persons 
10. What impressed you most when you first attended the SDA church?
[ ] building
[ ] people
[ ] message
[ ] youth activities
[ ] pastor
[ ] other (state)

11. Did you receive pre-baptismal instruction?

[ ] none [] poor [] fair [ ] satisfactory [ ] complete

12. Did you receive post-baptismal care?
[ ] none [ ] poor
[ ] fair
[ ] satisfactory
[ ] complete

13. How would you evaluate your present relationship with the church? [ ] a vital part [ ] one of the bunch [ ] unknown [ ] other

14. What do you like best in the church?

15. Is there anything you dislike? If so, what?

16. Have you ever thought about leaving the church? [ ] yes [ ] no If so, why?

II. How You See the Congregation

\section{A. Activities}

17. How do you perceive the activities of the church?
[ ] burdensome
[ ] necessary duty
[ ]

[ ] enjoyable

[ ] major source of satisfaction

18. How do you perceive the programs of the church?
[ ] ineffective
[ ] quite effective
[ ] partially effective
[ ] very effective

[ ] 
19. Which activity or custon do you feel should be phased out?

20. Which activity or activities do you feel should receive more emphasis?

B. Internal Environment

How do you evaluate the following aspects of the life of the church?

Zero Poor Fair Good Outstanding

21. Unity

22. Fellowship

[ ] [ ] [ ] [ ] [ ]

23. Interest and care shown visitors

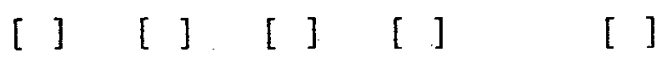

[ ] $\left[\begin{array}{lllll} & {[} & {[}\end{array}\right]$

24. Affirmation and support to members

[ ] [ ] [ ] [ ] [ ]

C. Worship

25. How do you perceive the worship services of your church?

[ ] dull [ ] inspiring

[ ] routine [ ] outstanding

[ ] average [ ] other

26. Reverence in the worship services is
[ ] poor
[ ] average
[ ] good
[ ] excellent

27. In which of the following do you most feel God's presence?

[ ] Sabbath School [ ] Sabbath worship [ ] Prayer meeting

[ ] Communion services [ ] other

28. How would you evaluate your attendance at services? (circle one)

$\begin{array}{llllllr} & \text { Zero } & - & \text { Average } & \text { Excellent } \\ \text { Sabbath School } & 0 & 1 & 2 & 3 & 4 & 5 \\ \text { Sabbath worship } & 0 & 1 & 2 & 3 & 4 & 5 \\ \text { Prayer meeting } & 0 & 1 & 2 & 3 & 4 & 5\end{array}$


D. Preaching

29. In general, how do you perceive the preaching at your church?
[ ] poor
[ ] routine
[ ] challenging
[ ] inspiring
[ ] excellent

30. The best sermons I remember were on: (subject)

1.

2.

E. Finances

31. The financial demands of the church are:

[ ] excessive [ ] affordable [ ] normal [ ] insignificant

F. Outreach

32. Your participation in the outreach program is:
[ ] poor
[ ] occasional
[ ] active
[ ] very active

33. Your participation helps you spiritually [ ] zero
[ ] sometimes
[ ] quite a bit
[ ] a great dea1

G. Building

34. The church facilities are [ ] inadequate [ ] not representative

[ ] need improvement [ ] good [ ] excellent

\section{H. General}

35. What do you think is the main cause for loss of interest and separation from the church?

[. ] doctrinal disagreement

[ ] problems with leaders

[ ] lack of pastoral care

[ ] problems with members

[ ] problems of the individual

[ ] other 
Naine Phone ( )
Last
First

Street City

State Zip

1. [ ] male [ ] female; [ ] single [ ] divorced [ ] married [ ] widowed

2. Present age:

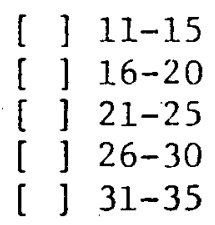

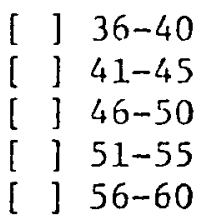

[ ] $6.1-65$

[ ] $66-70$

[] $71-75$

[ ] $76-80$

[ ] 81 or older

3. Age when baptized:
[ ] 10 or under [ ] 26-30
[ ] 11-15
[ ] $31-35$
$\begin{array}{ll}\text { [ ] } & 46-50 \\ {[\text { ] }} & 51-54 \\ {[\text { [ ] }} & 55-60 \\ {[]} & 61-65\end{array}$
[ ] $66-70$
[ ] 71-75
[ ] $16-20$
[] $36-40$
[ ] $21-24$
[] $41-45$
[ ] $76-80$
[ ] 81 or older

4. How long were you in the church?
[ ] less tian a year
[ ] 1-5 years
[ ] 6-10 vears
[ ] 11-1j years
[ ] 16-20 years

[ ] $21-25$ years

] $31-35$ years

[ ] 36-40 years

[] 41-45 years

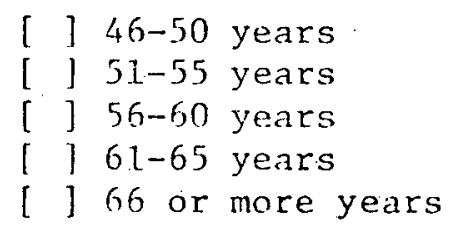

5. How far Eron the church do you live?

In miles:

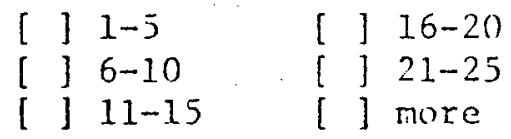

In time:

[ ] 15 min. [ ] 1 hour

[ ] $30 \mathrm{~min}$ [ ] $1 \mathrm{hr} .15 \mathrm{~min}$.

[ ] $45 \mathrm{~min}$. [ ] more

6. How many other members of your family are in our congregation? (circle one)
01
2.345
67
8910
$11 \quad 12 \quad 13 \quad 14$ more

7. Have you ever been a member of another SDA church? [ I yes [ ] no

8. Have you been a member of another denomination?
[ ] yes [ ] no Which one?

9. How did you get acquainted with the SDA church?
[ ] family
l 1 literature
1 radio/rv
l J friends
I l evangetistic campaign
1 orlicir (state)
I Ischool
I lay porsons 
10. What impressed you most. when you first attended the suld church?
[ ] building [ ] people
[ ] message [ ] youth activities:
[ ] pastor [ ] other (state)

11. Did you recelve pre-baptismal instruction?

[] none [ ] poor [ ] Eair I ] satisfactory [ ] complete

12. Did you receive post-baptismal care?

[] none [] poor [] fair [ ] satisfactory [ ] complete

13. How would you evaluate your relationship with the church?

[ ] a vital part [ ] one of the bunch [ ] unknown

[ ] other

14. What did you like best in the church?

15. Was there anything you disliked? If so, what?

16. Reasons why you left the church?

II. How You See the Congregation

\section{A. Activities}

17. How do you perceive the activities of the church?
[ ] burdensome
[ ] necessary duty
[.]
[ ] enjoyable
[ ] major source of satisfaction

18. How do you perceive the programs of the church?
[ ] ineffective
[ ] partially effective
[ ]
[ ] quite effective.
[ ] very effective 
19. Which activity or custon do you leel should be phased out?

20. Which activity or activities do you feel should receive more emphasis?

B. Internal Enviroment

How do you evaluate the following aspects of the life of the church? Zero Poor Fair food Outstanding

21. Unicy

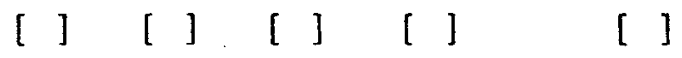

22. Fellowship

$\left[\begin{array}{llllll}] & {[} & {[}\end{array}\right] \quad[] \quad[]$

23. Interest and care shown visitors

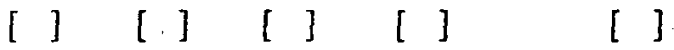

24. AEFimation and support to meniers

$\left[\begin{array}{llllll}] & {[}\end{array}\right] \quad\left[\begin{array}{ll}] & {[}\end{array}\right]$

C. Worsinip

25. Hor do you perceive the worship services of your church?
[ ] dul1
[ ] routine
[ ] inspiring
[ ] average
[ ] outstanding
[ ] other

26. Reverence in the worship services was
[.] poor
[ ] average
[ ] good
[ ] excellent

27. In which of the following did you nost feel Cod's presence?

[ ] Sabbath school [ ] Sabbath iorship [ ] Prayer meteting [ ] Communion services [ ] other

28. How would you evaluate your attendance at services? (circle one)

\begin{tabular}{|c|c|c|c|c|c|c|}
\hline \multirow[b]{2}{*}{ Sabrath sehool } & \multirow{2}{*}{$\begin{array}{l}\text { Zero } \\
0\end{array}$} & \multirow{2}{*}{ 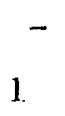 } & \multicolumn{2}{|c|}{ Avtrage } & \multicolumn{2}{|c|}{ Fxcellent } \\
\hline & & & 2 & 3 & 4 & 5 \\
\hline Sahbath worship & 0 & 1 & 2 & 3 & 4 & \\
\hline Pravere ment ins: & 0 & 1 & 2 & 3 & $\iota_{4}$ & 5 \\
\hline
\end{tabular}


D. Preaching:

29. In general, liow did you perceive the proaching at the church?

[ ] poor [ ] routine [ ] challenging [ ] inspiring

[.] excellent

30. The best sermons I remember vere on: (subject)

1.

2 .

\section{E. Finances}

31. The Einancial demands of the church were:

[ ] excessive [] affordable [ ] normal [ ] insignificant

F. Outreach

32. Your participation in the outreach program was:
[ ] poor
[ ] occasional
[ ] active
[ ] very active

33. Your participation helped you spiritually

[ ] zero

[ ] sometimes. [ ] quite a bit [ ] a great deal

G. Building

34. The church facilities are [ ] inadequate [ I not representative

[ ] need improvement [ ] good [ ] excellent

\section{H. General}

35. What do you think is the main cause for loss of interest and separation from the church?

[ ] doctrinal disagreement

[] problems with members

[ ] problems with leaders

[ ] problems of the individual

[ ] lack of pastoral care

[ ] other 
36. Do you have any specific recommendations for changes in the church?

37. Are there areas of church life which you feel should be explored but for which you have no specific recommendations at this tine? [ ] yes [ no]

If so, what?

38. Did you join a church of another denomination? [ ] yes [ ] no If so, which?

39. Do you consider yourself an Adventist? [ ] yes [ ] no

40. Would you like to return to the church? [ ] yes [ ] no

[ ] maybe someday [ ] not sure Why? 
APPENDIX B

SUGGESTED TOPICS FOR THE STUDY GROUPS 
TOPIC 1

FELLOWSHIP

\section{Diagnosis}

1. How would you evaluate now the reception given you the first time you visited this church?

2. Which aspects impressed your positively and which negatively?

3. In that which relates to the life of the church as a family,

a. What do you like mo-t?

b. Are there some things you dislike?

4. How would you evaluate the spirit that is manifested in the church? Love? Indifference? Friction?

5. How would you evaluate the present interest in and attitude shown visitors?

\section{Solutions}

1. What could be done to improve the care of:

a. Visitors

b. Those who are ill

c. Those who are discouraged

d. Those who are facing problems (family, lack of job, finances, etc.)

e. Children and young people

f. New members (by transfer, baptism, or profession of faith)?

2. What could be done to

a. Improve the spirit of friendship, brotherhood, unity, fellowship?

b. Avoid conflicts?

3. Additional ideas or suggestions. 
TOPIC 2

WORSHIP ANI) ADORATION

\section{Diagnosis}

1. When a worship service is closed, do you have the feeling that you have been in communion with God?

2. Which do you think is more important, the quality of the service or your attitude at the worship hour?

3. What do you consider to be obstacles to true adoration?

4. Are you satisfied with the way the congregation participates in singing?

\section{Solutions}

1. What habits or practices related to the worship hour should be avoided?

2. What habits or practices related to the worship hour should be promoted?

3. In the case of this church, how do the following affect the spirit of worship?
a. The building
2. The P.A. system
c. The work of deacons
d. The music
e. The length of the services
f. Other aspects

4. What suggestions would you give to improve the spirit of worship?

5. What ideas would you offer to transform every service into an act of real adoration?

6. What ideas would you suggest to foster a more active participation of all worshipers at the services?

7. Additional ideas or suggestions. 
TOPIC 3

PREACIIING

\section{Diagnosis}

1. What kind of sermons feed you spiritually?

2. What kind of sermons are not a help or an inspiration to you?

3. Does preaching in general provide you with solutions to your problems or worries, or produce feelings of fear, anxiety, or guilt?

\section{Solutions}

1. How long should a Sabbath morning sermon be?

2. Should more opportunities be given to lay people of the church to preach in the services?

3. What recommendations or suggestions would you give to whoever has the task of preaching? What should he avoid? What should he do?

4. How should the Bible be used in preaching? Do you have any recommendations?

5. How should the Spirit of Prophecy be used in preaching? Do you have any recommendations?

6. Additional ideas or suggestions.

TOPIC 4

THE OUTREACH PROGRAM

I. Diagnosis

1. What kind of missionary work do you most enjoy doing?

2. Are you spiritually helped by our participation in outreach programs?

3. What things help and inspire you to do missionary work?

What inspires you most while doing missionary work? 
4. What things discourage you from doing missionary work?

What discourages you most while doing missionary work?

II. Solutions.

1. What kind of materials should the church have to encourage missionary participation?

2. What kind of training would you receive to be more effective in doing the job?

3. Could you identify any weaknesses in the outreach program of this church? If so, what practical solutions would you give?

4. What recommendations would you give to the pastor and the leaders of the Lay Activities Department of the church?

5. Other ideas and suggestions.

TOPIC 5

PRAYER MEETINGS

I. Diagnosis

1. How many members of this group regularly attend the mid-week prayer meetings?

2. Why do you attend?

3. Why do you not attend?

II. Solutions

1. What type of meeting do you think would be ideal?
a. Hour
b. Duration
c. Music and singing
d. Preaching
e. Prayer bands' (groups)
f. Other activities

2. How should the congregation participate in the mid-week service? 
3. What topics or type of studies would you prefer?

4. What suggestions would you give to improve attendance?

5. Would it be better to have the meetings at member's homes on a rotating basis?

6. Additional ideas or suggestions.

TOPIC 6

THE CHURCH AND MONEY

I. Diagnosis

1. Do you think that the church asks for too much money?

2. What has your experience been in participating in the Christian stewardship plan?

II. Solutions

1. Do you think that the church should change the usual form of collecting the offerings during the services?

2. Do you have some other suggestions or ways to obtain money to support the program of the church?

3. How could offerings best be gathered to have them form a part of the act of adoration to God?

4. What is your opinion about financial campaigns conducted from the pulpit? How could this facet be improved?

5. Would you like to have more frequent financial reports from the church treasurer?

6. Additional ideas or suggestions.

TOPIC 7

THE BUILDING AND ITS FACILITIES

I. Diagnosis

1. What characteristics of the church facilities do you like most?

2. What cliaracteristicis do you disilike? 
II. Solutions

1. What could be done to make the building more attractive and practical?

a. Interior
(1) The sanctuary
(2) Children's rooms
(3) Recreational facilities
(4) Location or arrangement of pews
(5) Platform
(6) Choir location
(7) Library, reading room
(8) Paint: present condition, colors
(9) Ventilation: Air conditioning, heating system
(10) Illumination: natural, artificial

b. Exterior
(1) Paint: present condition, colors
(2) Shrubbery and 1 awn
(3) I11umination
(4) Parking facilities

\section{c. Equipment}

(1) Sound system

(2) Musical instruments

2. Do you think it would be profitable to have the church open for more than the worship services, such as for periods of meditation, play, or rest?

3. Additional ideas or suggestions 
TOPIC 8

THE CHURCH AND THE COMMUNITY

I. Diagnosis

1. Are the church and its message we11 known in the community it serves?

2. Does the church have a good name in the community?

3. Is the church doing something to benefit the community other than preaching its message?

II. Solutions

1. In what ways could the church exert a stronger influence on the life of the community?

2. How could the church best relate with the leaders of the community?

3. What kind of community service programs could Seventh-day Adventist youth develop?

4. How could the Community Welfare Center have a greater impact in the community?

5. In what way could the church enter into the communication and information channels of the community?

6. How could the church take better advantage of special occasions or events of the country, state, or city?

7. Additional ideas or suggestions

TOPIC 9

YOUTH

\section{Diagnosis}

1. Share what the personal analysis and the survey revealed.

2. Report on the number and percentage of young people in the congregation.

3. Analyze possible lowal confricts with youth.

4. Share the concerns and goals of the young people. 


\section{Solutions}

1. How to improve:

a. Relationship between adults and youth

b. The spiritual life

c. The social activities

d. The recreational facilities and program

2. How to involve youth in the outreach program of the church.

3. How to preach successfully to young people. 
APPENDIX C

RESULTS OF THE SURVEY AMONG MEMBERS 
SURVEY

DALLAS AND HOUSTON COMPARED BY PERCENTAGES

\begin{tabular}{lcc} 
Dallas & $\begin{array}{c}\text { No. of } \\
\text { respondents }\end{array}$ & Percentage \\
\cline { 2 - 3 } & 110 & 58.5 \\
Houston & 78 & -41.5
\end{tabular}

1. $\underline{\text { Sex }}$

$\underline{\text { Sex }}$

Female

Male

Da11as

Houston

Total

46.4

53.9

49.5

50.0

43.6

47.3

2. Present Age

\begin{tabular}{rrrr}
\multicolumn{1}{c}{ Age } & Da11as & Houston & Tota1 \\
-15 & 1.8 & 1.3 & 1.6 \\
$16-20$ & 12.7 & 24.4 & 17.6 \\
$21-25$ & 13.6 & 16.7 & 14.9 \\
$26-30$ & 20.9 & 21.8 & 21.3 \\
$31-35$ & 9.1 & 6.4 & 8.0 \\
$36-40$ & 8.2 & 5.1 & 6.9 \\
$41-45$ & 9.1 & 6.4 & 8.0 \\
$46-50$ & 5.5 & 6.4 & 5.9 \\
$51-55$ & 0.9 & 2.6 & 1.6 \\
$56-60$ & 4.6 & 2.6 & 3.7 \\
$61-65$ & 4.6 & 2.6 & 3.7 \\
$66-70$ & 2.7 & 1.3 & 2.1 \\
$71-75$ & 0.9 & - & 0.5
\end{tabular}


3. Age When Baptized

\begin{tabular}{rrrr} 
Age & Dallas & Houston & Total \\
\cline { 2 - 3 }-15 & 30.0 & 33.3 & 31.4 \\
$16-20$ & 16.4 & 15.4 & 16.0 \\
$21-25$ & 18.2 & 15.4 & 17.0 \\
$26-30$ & 11.8 & 14.1 & 12.8 \\
$31-35$ & 6.4 & 6.4 & 6.4 \\
$36-40$ & 0.9 & 2.6 & 1.6 \\
$41-45$ & 1.8 & 3.9 & 2.7 \\
$46-50$ & 3.6 & - & 2.1 \\
$51-55$ & 1.8 & - & 1.1 \\
$56-60$ & 0.9 & - & 0.5 \\
$61-65$ & 0.9 & - & 0.5 \\
$66-70$ & 0.9 & 1.3 & 1.1 \\
$71-75$ & - & - & -
\end{tabular}

4. Time in the Church

Years

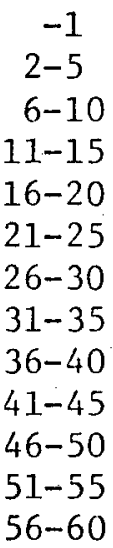

Dallas

16.4

22.7

11.0

14.6

11.0

8.2

4.6

0.9

3.6

0.9

0.9

1.8
Houston

10.3

25.6

7.7

14.1

16.7

15.4

2.6

1. 3

$-$

2.6

$-$

$-$
Total

13.8

23.9

2.6

14.4

13.3

11.2

3.7

1.1

2.1

0.5

1.6

1.1

5. Member of Another SDA Church

\section{Answer}

Yes

No

No Ans
Da11as

40.2

30.0

29.1
Houston

39.7

35.9

24.4
Total

40.4

32.5

27.1 
6. Member of Another Denomination

\begin{tabular}{lccr} 
Denomination & Dallas & Houston & Total \\
\cline { 2 - 3 } & & & \\
Roman Catholic & 37.3 & 20.5 & 30.3 \\
Baptist & 3.6 & 1.3 & 2.7 \\
Presbyterian & 0.9 & - & 0.5 \\
Pentecostal & 0.9 & 1.3 & 1.1 \\
Methodist & - & - & 0.9 \\
Church of God & 1.8 & 7.7 & 2.3 \\
$\quad 7$ th Day & & &
\end{tabular}

7. Means by Which They Came to the Church

\begin{tabular}{lcrrr}
\multicolumn{1}{c}{ Means } & Dallas & Houston & Total \\
\cline { 2 - 2 } Family & & & \\
Friends & 61.8 & 53.9 & 58.6 \\
Evangelistic Camp. & 15.5 & 24.4 & 19.2 \\
Literature & 12.7 & 2.6 & 8.2 \\
School & 2.7 & 6.4 & 4.3 \\
Radio & - & 2.6 & 1.1 \\
Other & 2.7 & 3.9 & 3.2 \\
& 2.7 & 2.6 & 2.7
\end{tabular}

8. What Impressed Most

Impressed most

\begin{tabular}{l} 
by \\
\hline Building \\
Message \\
Pastor \\
People \\
Program \\
Other
\end{tabular}

Da11as Houston Tota1

$\begin{array}{rrr}1.8 & - & 1.1 \\ 53.7 & 59.0 & 55.9 \\ 9.1 & 7.7 & 8.5 \\ 12.7 & 10.3 & 11.7 \\ 6.4 & 6.4 & 6.4 \\ 6.4 & 6.4 & 6.4\end{array}$


9. Distance from the Church (Miles)

\begin{tabular}{cccc} 
Miles & Dallas & Houston & Total \\
\cline { 2 - 3 }-1 mile & 2.7 & 25.6 & 12.2 \\
$1-5$ & 47.3 & 33.3 & 41.5 \\
$6-10$ & 14.6 & 25.6 & 19.2 \\
$11-15$ & 15.5 & 1.3 & 9.6 \\
$15-20$ & 10.9 & - & 6.4 \\
$21-25$ & 0.9 & 1.3 & 1.0
\end{tabular}

10. Members of the Family Also SDA

\begin{tabular}{crrr} 
Number & Dallas & Houston & Tota1 \\
\hline 0 & 10.9 & 19.2 & 14.4 \\
1 & 8.2 & 5.1 & 6.9 \\
2 & 11.8 & 11.5 & 11.7 \\
3 & 20.9 & 2.6 & 13.3 \\
4 & 10.0 & 3.9 & 7.5 \\
5 & 9.1 & 2.6 & 6.4 \\
6 & 2.7 & 5.1 & 3.7 \\
7 & 1.8 & 6.4 & 3.7 \\
8 & 2.7 & 1.3 & 2.1 \\
9 & 2.7 & 6.4 & 4.3 \\
more & 10.0 & 26.9 & 17.0 \\
a11 & 1.8 & 3.9 & 2.7
\end{tabular}

11. Evaluation of Relationship with the Church

Degree of

Relationship Dallas Houston Total

Vital

Enjoying fellowship

Unknown

42.7

50.0

35.1

2.6

45.8

other (discipline)

4.7
-5

1.3

39.9

4.3

0.5 
12. Evaluation of Attendance at Sabbath School

\begin{tabular}{lccr} 
Scale & Dallas & Houston & Total. \\
\cline { 2 - 2 } 0 (none) & 3.6 & 1.3 & 2.7 \\
1. & 1.9 & 2.6 & 1.6 \\
2 & - & 2.6 & 1.1 \\
3 & 4.6 & 5.1 & 4.8 \\
4 & 1.8 & 18.0 & 8.5 \\
5 (regular) & 79.1 & 61.5 & 71.8
\end{tabular}

13. Evaluation of Attendance at Worship Service

$\begin{array}{lccc}\text { Scale } & \text { Dallas } & \text { Houston } & \text { Total } \\ & & & \\ 1 & - & - & - \\ 2 & 0.9 & 1.3 & 1.1 \\ 3 & 0.9 & 2.6 & 1.6 \\ 4 & 2.7 & 3.9 & 3.2 \\ 5 \text { (regular) } & 1.8 & 9.0 & 4.8 \\ & 83.6 & 75.6 & 80.3\end{array}$

14. Evaluation of Attendance at Prayer Meeting

$\begin{array}{lrrrr}\text { Scale } & \text { Dallas } & & \text { Houston } & \text { Total } \\ 0 \text { (none) } & 17.3 & & 19.7 \\ 1 & 1.8 & 14.1 & 6.9 \\ 2 & 10.0 & 12.8 & 11.2 \\ 3 & 11.8 & 10.3 & 11.2 \\ 4 & 11.8 & 10.3 & 11.2 \\ 5 \text { (regular) } & 33.6 & 15.4 & 26.1\end{array}$

15. Evaluation of Pre-baptismal Instruction Received

\begin{tabular}{lccc} 
Degree of Instruction & Dallas & Houston & Total \\
\cline { 3 - 5 } Little & & & \\
Acceptable & 11.8 & 20.5 & 15.4 \\
Satisfactory & 14.6 & 20.5 & 17.0 \\
Complete & 26.4 & 15.4 & 21.9 \\
& 44.6 & 39.7 & 12.6
\end{tabular}


16. Evaluation of Post-baptismal Care Received

\begin{tabular}{lrrr} 
Degree of Care & Dallas & Houston & Total \\
\cline { 3 - 4 } & & & \\
Little & 23.6 & 30.8 & 26.6 \\
Acceptable & 19.1 & 9.0 & 18.5 \\
Satisfactory & 19.1 & 26.9 & 22.3 \\
Complete & 30.9 & 18.0 & 26.1
\end{tabular}

17. Tempted to Leave the Church?

\begin{tabular}{lcccc} 
Answer & Da1las & & Houston & Tota1 \\
\cline { 2 - 2 } Yes & 32.7 & & 25.6 & 29.8 \\
No & 40.0 & 53.9 & 45.7 \\
No Answer & 27.3 & 20.5 & 23.9
\end{tabular}

18. Evaluation of Activities of the Church

Degree of

enjoyment

Tiresome

Unavoidable duty

Pleasant

Greatest source

of satisfaction
Dallas

2.7

10.0

5.3 .6

30.0

7.7

3.9

57.7

23.1

19. Evaluation of the Programs of the Church

Degree of

effectiveness

Ineffective

Partially effective

Effective

Very effective
Dallas

$-$

25.5

50.0

21.9
Houston

9.0

37.2

26.9

15.4
4.8

7.5

55.3

27.1
6.6

22.3

26.1 
20. Unity among Members

\begin{tabular}{lrrr} 
Evaluation & Dallas & Houston & Total \\
\cline { 3 - 4 } Nothing & & & \\
Poor & 2.7 & 9.0 & 5.3 \\
Acceptable & 42.7 & 43.6 & 43.1 \\
Good & 26.4 & 18.0 & 22.9 \\
Excellent & 22.7 & 20.5 & 21.8 \\
& 2.7 & 5.1 & 3.7
\end{tabular}

21. Fellowship

Evaluation

Da11as

Houston

Tota1

Nothing

Poor

3.6

7.7

33.3

29.5

15.4

3.9

5.3

36.2

30.3

17.3

16.5

Excellent

3.6

3.7

22. Assistance to Visitors

Evaluation

Dallas

Houston

Total

Nothing

Poor

4.6

12.8

8.0

53.6

29.7

47.9

24.6

14.1

14.1

20.2

Good

10.9

2.7

2.0

12.2

5.3

23. Affirmation to Members

Evaluation

Dallas

Houston

Total

Nothing

5.5

5.1

5.3

Poor

30.9

21.8

27.1

Acceptable

29.1

30.8

29.8

17.3

19.2

18.1

Excellent

8.2

16.7

11.7 
24. Evaluation of the Worship Services

\begin{tabular}{lcrr}
$\begin{array}{l}\text { Quality of } \\
\text { Services }\end{array}$ & Dallas & Houston & Total \\
\cline { 1 - 1 } Boring & - & 3.9 & 1.6 \\
Routine & 14.6 & 20.5 & 17.0 \\
Acceptable & 30.9 & 32.1 & 31.4 \\
Inspiring & 30.0 & 30.8 & 30.3 \\
Excellent & 20.0 & 11.5 & 16.5
\end{tabular}

25. Enjoyment of God's Presence

\begin{tabular}{lrrr}
\multicolumn{1}{c}{ Service } & Dallas & Houston & Total \\
Sabbath school & 16.6 & 31.4 & 19.2 \\
Worship service & 58.9 & 45.3 & 60.1 \\
Prayer meeting & 23.8 & 15.1 & 13.8 \\
Other & 0.7 & 2.3 & 3.2
\end{tabular}

26. Evaluation of Reverence at the Services

\begin{tabular}{lrrr}
$\begin{array}{l}\text { Degree of } \\
\text { Reverence }\end{array}$ & Da11as & Houston & Tota1 \\
\cline { 2 - 3 } Poor & 40.0 & 52.6 & 45.2 \\
Acceptable & 25.5 & 20.5 & 23.4 \\
Good & 24.6 & 15.4 & 20.7 \\
Excellent & 5.5 & 9.0 & 6.9
\end{tabular}


27. Evaluation of Preaching

Quality of

Preaching

\begin{tabular}{lrrrr}
\multicolumn{1}{c}{ Preaching } & Dallas & Houston & Total \\
\cline { 2 - 3 } Poor & 2.7 & & 7.7 & 4.8 \\
Routine & 14.6 & & 42.3 & 26.1 \\
Challenging & 10.0 & & 6.4 & 8.5 \\
Inspiring & 33.6 & & 20.5 & 28.2 \\
Excellent & 25.5 & 11.5 & 19.7
\end{tabular}

28. Evaluation of Financial Demands

$\begin{array}{lrrrr}\text { Evaluation } & \text { Dallas } & \text { Houston } & \text { Total } \\ \text { Excessive } & & & & \\ \text { Affordable } & 24.6 & & 18.0 & 12.8 \\ \text { Reasonable } & 53.6 & & 53.9 & 23.4 \\ \text { Minimum } & 3.6 & 1.9 & 53.8 \\ & & & 2.7\end{array}$

29. Participation in Outreach Program

Degree of

Participation

Da1las Houston

$\underline{\text { Tota1 }}$

Poor

25.5

32.1

28.2

Occasional

46.4

35.9

42.0

Permanent

7.3

15.4

10.6

Decisive

17.3

7.7

13.3 
30. Participation He1ps Spiritually

Degree of

Spiritual Ilelp

Da11as

Houston

Tota1

Not at all

Sometimes

1.8

2.6

19.1

10.3

2.13

Effectively

49.1

39.7

15.4

Indispensable

20.0

30.8

45.2

24.8

31. Material Facilities of the Church

\begin{tabular}{|c|c|c|c|}
\hline Quality & Da11as & Houston & Total \\
\hline Inadequate & 1.8 & 1.3 & 1.6 \\
\hline Not representative & 2.7 & 10.3 & 5.9 \\
\hline Needs improvement & 68.2 & 16.7 & 46.8 \\
\hline Good & 18.2 & 41.0 & 27.7 \\
\hline Excellent & 2.7 & 24.4 & 11.7 \\
\hline
\end{tabular}

32. Reasons for Dropouts Given By Present Members

\section{Reasons}

Disagreement with doctrines

Problems among members

Problems with leadership

Problems of the individual

Lack of pastoral care.

other
Dallas

7.3

47.3

3.6

15.5

1.8

1.8
Houston

$$
\begin{array}{r}
- \\
47.4 \\
2.6 \\
21.8 \\
18.0 \\
1.3
\end{array}
$$

Total

4.3

47.3

3.2

18.1

8.5

1.6 


\section{SURVEY}

Genera1 Information

\section{$\underline{\text { Item }}$}

Dallas

Houston

Total

Item
Female
Male
Catholic [background]
Tempted [to leave church]
16-25 bears of age]
26-30 bears of age]

$$
\text { No. }
$$

$\%$

No.

$\%$

No.

$\begin{array}{llll}51 & 54.8 & 42 & 45.2\end{array}$

93

$\begin{array}{llll}55 & 61.8 & 34 & 38.2\end{array}$

89

$\begin{array}{llll}41 & 71.9 & 16 & 28.1\end{array}$

57

$\begin{array}{llll}36 & 64.2 & 20 & 35.7\end{array}$

56

$\begin{array}{llll}29 & 47.5 & 32 & 52.4\end{array}$

$\begin{array}{lll}23 & 57.5 \quad 17 \quad 42.5\end{array}$

61

40

\section{Sex}

\begin{tabular}{|c|c|c|c|c|}
\hline Sex & Catholic & Tempted $^{b}$ & $16-25^{c}$ & $26-30^{\circ}$ \\
\hline Female $^{e}$ & 54.4 & 42.9 & 55.7 & 42.6 \\
\hline Male & 43.9 & 57.1 & 42.6 & 57.5 \\
\hline
\end{tabular}

a Dallas 71.9; Houston 28.1

$\mathrm{b}_{\text {Dallas } 64.3 \text {; Houston } 35.7}$

CDallas 47.5; Houston 52.5

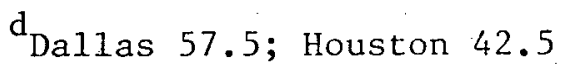

e Dallas 54.8; Houston 45.2

$\mathrm{f}_{\text {Dallas }} 61.8$; Houston 38.2 
2. Present Age

\begin{tabular}{rrrrrr} 
Age & Female & Male & Catholic & Tempted & 16-25 \\
\cline { 2 - 3 }-15 & 2.1 & 1.1 & 1.7 & 1.8 & 54.1 \\
$16-20$ & 23.7 & 12.4 & 8.8 & 19.6 & \\
$21-25$ & 13.0 & 16.8 & 21.1 & 10.7 & \\
$26-30$ & 18.3 & 25.8 & 19.3 & 21.4 & \\
$31-35$ & 6.4 & 10.1 & 10.5 & 14.3 & \\
$36-40$ & 9.7 & 4.5 & 1.7 & 12.5 & \\
$41-45$ & 5.4 & 11.2 & 8.8 & 10.7 & \\
$46-50$ & 6.4 & 3.4 & 10.5 & 3.6 & \\
$51-55$ & 2.1 & 1.1 & 1.7 & 1.8 & \\
$56-60$ & 3.2 & 3.4 & 5.3 & 1.8 & \\
$61-65$ & 2.1 & 2.2 & 1.7 & 1.8 & \\
$66-70$ & - & 1.1 & 1.7 & 1.8 &
\end{tabular}

3. Age When Baptized

Age when

baptized Female Male. Catholic Tempted 16-25 26-30

$\begin{array}{rrrrrrr}-15 & 43.0 & 20.2 & 8.8 & 3.6 & - & 32.5 \\ 16-20 & 11.9 & 21.3 & 14.0 & 44.6 & - & 7.5 \\ 21-25 & 14.0 & 21.3 & 28.1 & 17.9 & - & 25.0 \\ 26-30 & 15.0 & 11.2 & 21.0 & 10.8 & 12.7 & 32.5 \\ 31-35 & 3.2 & 9.0 & 14.0 & 10.8 & 1.6 & - \\ 36-40 & 2.1 & 1.1 & 1.7 & 7.1 & - & - \\ 41-45 & 3.2 & 2.2 & 1.7 & 1.8 & - & - \\ 46-50 & 2.1 & 2.2 & 5.3 & 1.8 & - & - \\ 51-55 & 1.1 & 1.1 & 1.7 & 1.8 & - & - \\ 56-60 & 1.1 & - & - & - & - & - \\ 61-65 & - & 2.2 & - & - & - & - \\ 66+ & - & - & - & - & - & -\end{array}$


4. Time in the Church

$\begin{array}{rrrrrrrr}\text { Years } & \text { Female } & \text { Male } & \text { Catholic } & \text { Tempted } & & 16-25 & 26-30 \\ -1 & 10.7 & 18.0 & 31.6 & 1.8 & 19.6 & 20.0 \\ 2-5 & 27.0 & 21.3 & 33.3 & 14.3 & 34.4 & 25.0 \\ 6-10 & 8.6 & 11.2 & 12.3 & 16.1 & 9.8 & 7.5 \\ 11-15 & 11.8 & 12.7 & 3.5 & 10.8 & 16.4 & 5.0 \\ 16-20 & 18.2 & 9.0 & 3.5 & 17.9 & 8.2 & 17.5 \\ 21-25 & 10.7 & 12.4 & 3.5 & 17.9 & 9.8 & 15.0 \\ 26-30 & 2.1 & 4.5 & 1.7 & 14.3 & & - & 7.5 \\ 31-35 & 2.1 & - & - & 3.6 & - & - \\ 36-40 & 3.2 & 1.1 & 5.3 & 1.8 & & - & - \\ 41-45 & 2.1 & 1.1 & 1.7 & - & - & - \\ 46-50 & - & 2.2 & 1.7 & 1.8 & - & - \\ 51-55 & - & - & - & - & - & -\end{array}$

5. Member of Another SDA Church

$\begin{array}{lcccccc}\text { Answer } & \text { Female } & \text { Male } & \text { Catholic } & \text { Tempted } & \text { 16-25 } & \text { 26-30 } \\ \text { Yes } & 41.9 & 40.4 & 22.8 & 26.8 & 32.8 & 37.5 \\ \text { No } & 33.3 & 31.5 & 21.1 & -12.9 & 37.7 & 42.5 \\ \text { No Ans. } & - & - & - & 30.4 & - & -\end{array}$

6. Member of Another Denomination

\begin{tabular}{|c|c|c|c|c|c|}
\hline Denomination & Female & Male & Tempted & $16-25$ & $26-30$ \\
\hline Roman Catholic & 3.3 .3 & 28.1 & 26.8 & 27.9 & 27.5 \\
\hline Baptist & 3.2 & 2.2 & 3.6 & 1.6 & - \\
\hline Presbyterian & 1.1 & 1.1 & - & - & - \\
\hline Pentecostal & 1.1 & 1.1 & 1.8 & - & - \\
\hline Methodist & 1.1 & 1.1 & 1.8 & - & 2.5 \\
\hline Church of God, & & & & & \\
\hline 7 th-day & 3.2 & 3.4 & 3.6 & 8.2 & 2.5 \\
\hline
\end{tabular}


7. Means By Which They Came to the Church

\begin{tabular}{|c|c|c|c|c|c|c|}
\hline Means & Female & Male & Catholic & Tempted & $16-25$ & $26-30$ \\
\hline Family & 64.5 & 53.9 & 47.4 & 69.6 & 65.6 & 65.0 \\
\hline Friends & 16.1 & 23.6 & 28.1 & 7.1 & 18.0 & 17.5 \\
\hline \multicolumn{7}{|c|}{ Evangelistic } \\
\hline Campaign & 4.3 & 10.1 & 14.0 & 7.1 & 6.6 & 7.5 \\
\hline Literature & 4.3 & 4.5 & 3.5 & - & - & 2.5 \\
\hline School & 1.1 & 1.1 & 3.5 & 3.6 & 1.6 & - \\
\hline Radio & 4.3 & 2.2 & 3.5 & 5.4 & 4.9 & - \\
\hline other & 2.1 & 3.4 & - & 5.4 & 1.6 & 2.5 \\
\hline
\end{tabular}

8. What Impressed Most

Greatest

impression Female Male Catholic Tempted 16-25 26-30

$\begin{array}{lrrrrrr}\text { Building } & - & 2.5 & - & 3.6 & - & 2.5 \\ \text { Message } & 50.5 & 60.7 & 64.9 & 55.4 & 52.5 & 55.0 \\ \text { Pastor } & 9.7 & 7.9 & 15.8 & 5.4 & 9.8 & 10.0 \\ \text { People } & 14.0 & 10.1 & 10.5 & 14.3 & 13.1 & 7.5 \\ \text { Program } & 6.4 & 5.6 & 5.3 & 3.6 & 6.6 & 5.0 \\ \text { Other } & 6.4 & 6.7 & 3.5 & 10.8 & 8.2 & 7.5\end{array}$

9. Distance from the Church (Miles)

Miles Female. Male Catholic Tempted 16-25 26-30

$\begin{array}{rrrrrrr}-1 & 11.8 & 12.4 & 17.5 & 10.7 & 18.0 & 12.5 \\ 1-5 & 36.6 & 47.2 & 35.1 & 37.5 & 39.3 & 45.0 \\ 6-10 & 20.4 & 16.8 & 22.8 & 23.2 & 21.3 & 17.5 \\ 11-15 & 9.7 & 10.1 & 7.0 & 9.0 & 6.5 & 5.0 \\ 16-20 & 7.6 & 5.6 & 10.5 & 10.8 & 4.9 & 7.5 \\ 21-25 & 1.1 & 2.2 & - & 1.3 & 1.6 & 2.5\end{array}$


10. Other Members of the Family Also SDA

\begin{tabular}{|c|c|c|c|c|c|c|}
\hline $\begin{array}{c}\text { Number of } \\
\text { Members }\end{array}$ & Female & Male & Catholic & Tempted & $16-25$ & $26-30$ \\
\hline 0 & 17.2 & 11.2 & 21.1 & 8.9 & 22.9 & 17.5 \\
\hline 1 & 4.3 & 10.1 & 12.3 & 10.7 & 3.3 & 15.0 \\
\hline 2 & 16.1 & 7.9 & 17.5 & 8.9 & 4.9 & 22.5 \\
\hline 3 & 11.8 & 15.7 & 21.0 & 12.5 & 16.4 & 2.5 \\
\hline 4 & 3.2 & 10.1 & 3.5 & 12.5 & 3.3 & 2.5 \\
\hline 5 & 4.3 & 7.9 & 7.0 & 8.9 & 4.9 & 5.0 \\
\hline 6 & 4.3 & 3.4 & 1.7 & 1.8 & 6.6 & - \\
\hline 7 & 5.4 & 2.2 & 3.5 & 1.8 & 3.3 & 2.5 \\
\hline 8 & 4.3 & - & - & 1.8 & 1.6 & 2.5 \\
\hline More & 16.1 & 18.0 & 1.7 & 28.6 & 21.3 & 20.0 \\
\hline A11 & 3.2 & 2.2 & - & 1.8 & 1.6 & 5.0 \\
\hline
\end{tabular}

11. Evaluation of Relationship with the Church

Degree of

$\underline{\text { Relationship }}$

Female Male Catholic Tempted 16-25 26-30

$\begin{array}{lrrrrrr}\text { Vital } & 50.5 & 42.7 & 49.1 & 48.2 & 37.7 & 50.0 \\ \text { Enjoy Fellow- } & & & & & & \\ \quad \text { ship } & 36.6 & 43.8 & 35.1 & 39.3 & 50.8 & 32.5 \\ \begin{array}{l}\text { Unknown } \\ \text { Other (Dis- }\end{array} & 2.1 & 4.5 & 7.1 & 3.6 & 1.6 & 5.0 \\ \quad \text { cipline) } & - & 1.1 & 1.7 & 1.8 & - & -\end{array}$

12. Evaluation of Attendance at Sabbath School

\begin{tabular}{|c|c|c|c|c|c|c|}
\hline Evaluation & Female & Male & Catholic & Tempted & $16-25$ & $26-30$ \\
\hline 0 (none) & 2.1 & 3.4 & 1.7 & 1.8 & 4.9 & 5.0 \\
\hline 1 & 1.1 & 2.2 & - & 1.8 & 4.9 & - \\
\hline 2 & 1.1 & 1.1 & - & - & - & - \\
\hline 3 & 5.4 & 3.4 & 5.3 & 1.8 & 4.9 & 12.5 \\
\hline 4 & 10.8 & 6.7 & 14.0 & 12.5 & 16.4 & 5.0 \\
\hline 5 (regular) & 71.0 & 74.2 & 73.7 & 80.4 & 80.4 & 75.0 \\
\hline
\end{tabular}


13. Attendance Worship Service

\begin{tabular}{|c|c|c|c|c|c|c|}
\hline Evaluation & Fema le & Male & Catholic & Tempted & $16-25$ & $26-30$ \\
\hline 0 (none) & & - & - & - & - & - \\
\hline 1 & 1.1 & 1.1 & - & - & 3.3 & - \\
\hline 2 & 3.2 & - & - & - & 1.6 & 2.5 \\
\hline 3 & 2.2 & 4.5 & - & 5.4 & 6.6 & 2.5 \\
\hline 4 & 4.3 & 5.6 & 5.2 & 3.6 & 8.2 & 10.0 \\
\hline 5 (regular) & 82.8 & 78.7 & 86.0 & 87.5 & 75.4 & 32.5 \\
\hline
\end{tabular}

14. Attendance Prayer Meeting

Evaluation Female Male Catholic Tempted 16-25 26-30

$\begin{array}{lrrrrrr}0 \text { (none) } & 23.7 & 16.8 & 19.3 & 25.0 & 21.3 & 30.0 \\ 2 & 10.7 & 2.2 & 10.5 & 8.9 & 11.5 & 5.0 \\ 3 & 7.5 & 14.6 & 5.3 & 14.3 & 8.2 & 12.5 \\ 4 & 10.7 & 12.4 & 12.3 & 8.9 & 11.5 & 12.5 \\ 5 & 10.7 & 12.4 & 10.5 & 8.9 & 14.7 & 12.5 \\ \text { (regular) } & 21.5 & 30.3 & 33.3 & 30.4 & 18.0 & 22.5\end{array}$

15. Baptisma1 Instruction

Degree of

Instruction Female Male Catholic Tempted 16-25 26-30

$\begin{array}{llllllr}\text { Few } & 19.3 & 12.4 & 17.5 & 19.6 & 26.2 & 7.5 \\ \text { Acceptable } & 10.7 & 22.5 & 10.5 & 17.9 & 18.0 & 12.5 \\ \text { Satisfactory } & 20.4 & 23.6 & 35.1 & 23.2 & 18.0 & 25.0 \\ \text { Complete } & 48.3 & 37.1 & 36.8 & 39.3 & 34.4 & 52.5\end{array}$


16. Post-Baptismal Care

Degree of

Instruction

Few

30.1

Acceptable $\quad 14.0$

Satisfactory

Complete

17.2

30.1

\begin{abstract}
Male
\end{abstract}
Catholic

Tempted

$\underline{16-25} \quad 26-30$

24.7

31.6

15.8

32.1

8.9

31.1

22.5

14.6

22.8

28.1

19.6

33.9

13.1

22.5

$22.9 \quad 30.0$

17. Tempted to Leave the Church.

\begin{tabular}{|c|c|c|c|c|c|}
\hline Answer & Female & Male & Catholic & $16-25$ & $26-30$ \\
\hline Yes & 25.8 & 36.0 & 26.3 & 27.9 & 30.0 \\
\hline No & 50.5 & 41.6 & 57.9 & 50.8 & 52.5 \\
\hline No Answer & - & - & - & - & - \\
\hline
\end{tabular}

18. Evaluation of Activities of the Church

Degree of Enjoyment

Tiresome

Unavoidable duty

Pleasant

Greatest source

of satisfaction
Female Male Catholic Tempted 16-25 26-30

$\begin{array}{lllll}3.2 & 6.7 & 1.7 & 10.7 & 8.2\end{array}$

9.7

$4.5 \quad 3.5$

$45.2 \quad 67.4 \quad 56.1$

5.4

58.9

$8.2 \quad 2.5$

$57.4 \quad 50.0$

$32.2 \quad 20.2 \quad 38.6$

21.4

22.9

42.5 
19. Evaluation of the Programs of the Church

Degree of

Effectivness

Ineffective

Partially effective

Effective

Very effec-

tive

Fema1

Male

2.15

.6

8.2

\section{1}

30.3

22.8

46.4

22.9

35.0

33.

49.4

50.9

35.7

54.1

42.5

$26.9 \quad 12.4$

22.8

12.5

13.120 .0

20. Unity among Members

\begin{tabular}{|c|c|c|c|c|c|c|}
\hline Evaluation & Female & Ma1e & Catholic & Tempted & $16-25$ & $26-30$ \\
\hline Nothing & 6.4 & 3.4 & 1.7 & 5.4 & 8.2 & 5.0 \\
\hline Poor & 48.4 & 36.0 & 47.4 & 55.4 & 34.4 & 37.5 \\
\hline Acceptable & 18.3 & 29.2 & 28.1 & 28.6 & 21.3 & 35.0 \\
\hline Good & 23.7 & 21.3 & 21.0 & 7.1 & 31.1 & 17.5 \\
\hline Excellent & 1.1 & 6.7 & - & 1.8 & 3.3 & 5.0 \\
\hline
\end{tabular}

21. Fe11owship

Evaluation Female Male. Catholic Tempted 16-25 26-30

$\begin{array}{lrrrrrr}\text { Nothing } & 10.7 & - & 7.0 & 5.4 & 4.9 & 5.0 \\ \text { Poor } & 36.6 & 33.7 & 35.1 & 42.9 & 29.5 & 30.0 \\ \text { Acceptable } & 29.0 & 32.6 & 29.8 & 35.7 & 37.7 & 27.5 \\ \text { Good } & 16.1 & 18.0 & 24.6 & 10.7 & 16.4 & 22.5 \\ \text { Excellent } & 1.1 & 6.7 & - & 3.6 & 1.6 & 7.5\end{array}$

22. Assistance to Visitors

Evaluation Female. Male Catholic Tempted 16-25 26-30

$\begin{array}{lrrrrrr}\text { Nothing } & 11.8 & 4.5 & 10.5 & 5.4 & 11.5 & 7.5 \\ \text { Poor } & 46.2 & 48.3 & 52.6 & 62.5 & 47.5 & 40.0 \\ \text { Acceptable } & 20.4 & 21.3 & 21.1 & 12.6 & 1.8 .0 & 27.5 \\ \text { Good } & 10.7 & 14.6 & 12.3 & 7.1 & 13.1 & 12.5 \\ \text { Excellent } & 4.3 & 6.7 & 3.5 & .5 .4 & 3.3 & 12.5\end{array}$


23. Affirmation to Members

\begin{tabular}{|c|c|c|c|c|c|c|}
\hline Evaluation & Female & Ma1e & Catholic & Tempted & $16-25$ & $26-30$ \\
\hline Nothing & 7.5 & 3.4 & 8.8 & 21.4 & 6.6 & - \\
\hline Poor & 23.7 & 28.1 & 22.8 & 41.1 & 19.7 & 22.5 \\
\hline Acceptable & 31.2 & 30.3 & 31.6 & 28.6 & 29.5 & 32.5 \\
\hline Good & 18.3 & 19.1 & 21.0 & 16.1 & 21.3 & 17.5 \\
\hline Excellent & 12.9 & 10.0 & 10.5 & 3.6 & 14.7 & 20.0 \\
\hline
\end{tabular}

24. Evaluation of Worship Services

Quality of

Services Female Male Catholic Tempted 16-25 26-30

Boring

Routine

10.4

Acceptable

17.2

3.4

$-$

28.0

18.0

36.0

15.8

31.2

28.1

22.8

36.8

Excellent

19.3

13.5

21.1

.8
23.2
48.2
21.4
5.4

4.9

18.0

27.9

7.5

$31.1 \quad 27.5$

18.0

27.5

25. Enjoyment of God's Presence

Service

Sabbath school Worship service Prayer meeting Other
Female Male Catholic Tempted

$\begin{array}{rr}16.1 & 20.2 \\ 60.2 & 61.8 \\ 15.1 & 13.5 \\ 3.2 & 3.4\end{array}$

19.3

68.4

8.4

3.5
21.4

57.1

14.3

5.4 $\underline{16-25} \quad 26-30$

$27.9 \quad 10.0$

$54.1 \quad 70.0$

$13.1 \quad 10.0$

4.95 .0

26. Evaluation of Reverence

Degree of

Reverence

Female

Male Catholic

Tempted

16-25

$26-30$

Poor.

47.3

41.6

29.8

51.4

40.2

30.0

Acceptable

21.6

21.1

23.2

22.9

22.5

Good

18.3

24.8

38.6

19.6

14.7

37.5

10.5

$-$

11.5

5.0

$\begin{array}{ll}7.5 & 6.8\end{array}$

10.5 


\section{Evaluation of Preaching}

Quality of

Preaching

Poor

Routine

Challenging

Inspiring

Excellent

Female Male

Catholi
7.0
21.0
12.3
28.1
28.1

Tempted

$\underline{16-25} \quad \underline{26-30}$

$\begin{array}{rr}4.3 & 5.6 \\ 24.7 & 28.1 \\ 9.7 & 7.9 \\ 30.1 & 27.0 \\ 20.4 & 20.2\end{array}$

5.4

8.2

18.0

20.0

39.3

6.6

17.5

2.1

32.8

25.0

16.1

22.9

25.0

28. Evaluation of Financial Demands

\begin{tabular}{|c|c|c|c|c|c|c|}
\hline Evaluation & Female & Male & Catholics & Tempted & $16-25$ & $26-30$ \\
\hline Excessive & 12.9 & 12.4 & 8.8 & 21.4 & 19.7 & 7.5 \\
\hline Affordable & 19.3 & 29.2 & 22.8 & 35.7 & 14.7 & 32.5 \\
\hline Reasonable & 59.1 & 48.3 & 63.2 & 37.5 & 5.7 & 50.0 \\
\hline Minimum & 2.2 & 3.4 & 1.7 & 3.6 & 3.3 & 2.5 \\
\hline
\end{tabular}

29. Participation in the Outreach Program

Degree of

Participation

Poor

Occasional

Permanent

Decided

Female

$\underline{\mathrm{Mal}}$

Catholics

Tempted

$\underline{16-25} \quad \underline{26-30}$

33.3

20.2

29.8

52.9

40.3

21.4

46.4

39.320 .0

33.3

12.3

14.3

$42.6 \quad 47.5$

10.7

11.2

14.0

16.1

$6.6 \quad 12.5$

$8.2 \quad 17.5$

\section{Participation Helps Spiritua11y}

Degree of Spiritual Help

None at all

Sometimes

Effectively

Is indispensable

Female : Male Catholics Tempted 16-25 26-30

$\begin{array}{rrrrrr}3.2 & 1.1 & 1.7 & 3.6 & - & 2.5 \\ 15.1 & 14.6 & 19.3 & 19.6 & 16.4 & 12.5 \\ 43.0 & 49.4 & 45.6 & 48.2 & 50.8 & 42.5 \\ 23.7 & 27.0 & 24.6 & 25.0 & 22.9 & 42.5\end{array}$


31. Church Facilities

\begin{tabular}{|c|c|c|c|c|c|c|}
\hline Quality & Female & Ma1e & Catholic & Tempted & $16-25$ & $26-30$ \\
\hline Inadequate & 1.1 & 2.2 & 1.7 & 1.8 & 1.6 & - \\
\hline Not repre- & 6.4 & 5.6 & 3.5 & 18 & 131 & 25 \\
\hline Needs im- & & & & & 1. & 2.0 \\
\hline provement & 49.5 & 43.9 & 52.6 & 66.1 & 45.9 & 45.0 \\
\hline Good & 22.6 & 33.8 & 31.6 & 19.6 & 21.3 & 32.5 \\
\hline Excellent & 14.0 & 10.1 & 8.8 & 8.9 & 13.1 & 12.5 \\
\hline
\end{tabular}

32. Reasons for Dropouts

Reasons Female Male Catholic Tempted 16-25 26-30

Doctrinal disagreement

Human problems

Problems with leadership

Problems with individuals Lack of pastoral care Other rese

$\begin{array}{rrrrrr}5.4 & 3.4 & 8.8 & 3.6 & 4.9 & 2.5 \\ 49.5 & 46.1 & 45.6 & 60.7 & 46.4 & 45.0 \\ 4.3 & 2.2 & 7.0 & 3.6 & 3.3 & 5.0 \\ 20.4 & 16.8 & 15.8 & 17.8 & 22.9 & 22.5 \\ 5.4 & 11.2 & 9.0 & 5.4 & 13.1 & 5.0 \\ - & 3.4 & 1.7 & 3.5 & 3.3 & 2.5\end{array}$




\section{APPENDIX D}

REPORTS OF THE STUDY GROUPS 2 TO 6--DALLAS 
REPORT GROUP 2--DALLAS

WHEREAS the blessings received in participating in worship depend on both the attitude of the worshipper and the quality of the service itself, it was suggested:

1. Preparation of the worshipper. To encourage every worshipper to do thorough previous preparation at home and during the trip to church in order to be ready to worship "in spirit and in truth." This preparation should include:

a. Allowing enough time for the preparation at home and for the trip in order to avoid unnecessary haste and tensions

b. Avoiding, as far as possible, going through places such as shopping areas, or too crowded roads, in order to keep a relaxed attitude which will prepare the spirit for adoration. If this is not possible, to have music or to sing, thus being predisposed to adoration upon arriving at the sanctuary.

c. Arriving at the church early enough to devote time to reading and meditation. This does not hinder the manifestation of a spirit of joyful fellowship.

\section{Preparation of the service}

a. That those in charge of organizing the service prepare all details enough in advance so that every service may start and close at the appointed time

b. Avoid all kinds of interferences to the spirit of worship, such as avoidable delays or announcements or 
interruptions in the flow of the program. This can be avoided by thorough planning and preparation.

c. Since lack of reverence is an obstacle to true adoration, to start a campaign immediately aimed at creating a spirit of order and reverence during the worship hours. The following recommendations were presented:

(1) to use the back doors of the sanctuary located on both sides of the pulpit, as little as possible

(2) promptness in starting and closing a11 services

(3) use of music, which inspires worship

(4) that the campaign to foster reverence be conducted in a spirit of friendship, Christian love, and understanding, avoiding tensions

d. That preaching always be prepared with the aim of filling the needs of the hearers, in order to maintain their interest and attention

3. Additiona1 suggestions from the audience

a. To prepare a climate of worship through music, either live or previously recorded, during the fifteen minutes preceding every worship service

b. That ushers be located at the doors to receive and help seat people as they arrive

c. That, whenever possible, every member be seated from the beginning of the Sabbath school in the area where his/her class usually meets to avoid unnecessary movement: 
c. To keep the last two pews at each side of the sanctuary for mothers with children who cannot be in the mothers' room, thus allowing them to leave the place easily in case of need

d. That a person be designated to control the thermostat for the heater/air-conditioning

6. To renew the publication of the church bulletin

REPORT GROUP 3--DALLAS

Considering the role preaching plays in the upbuilding and growth of the church, it was suggested:

1. That more sermons be preached on prophecy and doctrine with strong Christocentric accent

2. That, as a general rule, sermons be between thirty and forty minutes in length

3. That Sabbath morning services be so planned as to allow the preaching service to begin at eleven and close at noon, trying to keep promptness throughout the various parts

4. That sermons be prepared with the object of upbuilding the congregation, and in no case to be used as a whip. This does not mean that rebuke or admonition should not be present. What should be avoided is the use of the pulpit to refer to personal problems.

5. To request preachers to carefully prepare sermons, avoiding superficiality

6. That in the Sabbath worship hour, priority be given to the sermon. In case of lack of time the children's story should be 
canceled, leaving enough time for the sermon.

7. That whenever possible, the pulpit be occupied by the pastor, leaving it to lay preachers only in case of emergency. When lay preachers are assigned to preach, that both preparation and delivery of the sermon be made in consultation and under the advice of the pastor.

8. To give study to the possibility of having a pulpit calendar so that the congregation may know beforehand the subjects to be presented

9. To begin again the practice of having the week of prayer for young people and for the church, inviting when it is possible a guest speaker

Additional recommendation from the congregation:

10. To organize and develop a training program for lay preachers

REPORT GROUP 4--DALLAS

The following suggestions were given as goals to be reached:

1. To give complete support to the activities of the "sunshine bands" going to sing and witness at hospitals and nursing homes

2. In order to improve participation, to organize the church according to the spiritual gifts of every member, assigning a leader to every group formed.

3. That the experienced members train the inexperienced through a direct on-the-job training process 
4. That activities planned for Sabbath afternoon be conducted always at the same time and according to schedule

5. To reap the results of the different radio programs, the following practical suggestions were presented:

a. To request from Elder N. Mulinari, the names and addresses of listeners to the program Amanecer in the Dallas area

b. That any campaign conducted in the Dallas area be advertised through the different radio programs

6. To emphasize the fact that success in the program of the church depends not only on the leadership, but on the attitude and participation of every individual member as well

7. That a person be designated to lead the campaign for better care of visitors at the church

8. That internal missionary work be organized, sending cards or visiting absent members Additional suggestions from the congregation

1. That appropriate material be provided for the work

2. That a training program for lay persons be organized as soon as possible

\section{REPORT GROUP 5--DALLAS}

Considering the importance of prayer meeting in improving the spiritual health of the church, it was suggested:

1. To increase attendance

a. That the services be transformed into deep spiritual gatherings 
b. In order to avoid routine, that the services be carefully prepared, making them as interesting as possible

c. That the topics to be dealt with be announced beforehand to promote a better preparation of the audience

d. That after participating in the services, every member share the message presented with those who did not attend, building up interest in regular attendance

e. That transportation be arranged for those who do not have their own transportation

2. To increase lay participation:

a. That interviews with members be conducted to share conversion experiences, special blessings received, etc.

b. That inspiring missionary experiences be shared with the other members of the congregation

c. That in every service a person or family present their most cherished Bible text and explain why it is a favorite

d. That the old practice of giving testimonies be renewed

e. That a series of studies on Daniel, Revelation, Isaiah, etc., be presented

f. That at least every quarter an evening be dedicated to visitors

g. That at least twice a year some kind of nusical 
program be conducted. on Wednesday evening

3. That, in order to share the blessings received, the services be recorded, keeping the tapes to share with those who missed that particular service

Additional suggestion from the congregation

1. That special study be given to the organization of a church choir which would practice in connection with the mid-week meeting

\section{REPORT GROUP 6--DALLAS}

WHEREAS tithe giving and offerings are a part of worship as an act of adoration, and in order to make their gathering an integral part of our praise to God, it was suggested:

1. That every member put aside and prepare at home the offerings and tithes he will bring to church

2. That special study be given to a systematic plan to avoid the gathering of too many offerings, by combining some of them in to one

3. That during Sabbath morning services, only two offerings be taken: the Sabbath School offering and the worship service offering

4. That special offerings be announced one or two weeks in advance to allow time for due preparation

5. That any request for money. from the pulpit be characterized by special tact and keeping due reverence

6. That the tithe envelopes be returned to the mombers 
as they leave the worship services

7. That deacons be organized into shifts so that everyone may know beforehand when he will collect the offerings

8. That the business meetings of the church be conducted at appropriate hours in order to get a larger attendance and participation, avoiding the consideration of financial questions that are not proper for the Sabbath hours

Additional suggestion presented by the congregation

1. That the treasury of the church present a financial report to the congregation at the end of every quarter 
SELECTED BIBLIOGRAPHY 
SELECTED BIBLIOGRAPHY

Books

Anderson, Gerald L., and Stransky, Thomas, eds. Mission Trends No. 2. Grand Rapids: Wm. B. Eerdmans, 1975.

Anderson, James D. To Come Alive. New York: Harper and Row, Publishers, 1973.

Autrey, C. E. Basic Evangelism. Grand Rapids: Zondervan, 1974.

Barnes, Albert. Notes on the Epistles of Paul. New York: Harper and Brothers, 1864.

Barth, Marcus. The Broken Wa11: A Study of Ephesians. Chicago: The Judson Press, 1959.

Bennis, Warren C. Changing Organizations. New York: McGraw Hil1, 1966.

Billy Graham Ev. Assn. Great Churches Today. Minneapolis: World Wide Pub., 1973.

Bloesch, Donald G. Wellsprings of Renewal. Grand Rapids: Vm. B. Eerdmans, 1974.

- The Reform of the Church. Grand Rapids: Wri. D. Eerdmans, 1974.

Bonhoeffer, Dietrich. Life Together. New York: Harper and Row, 1954.

Bradford, Charles E. Preaching to the Times. Washington, D.C.: Review and Herald Pub. Assn., 1975.

Briste1, C. W. Pastoral Care in the Church. New York: Harper and Row, 1964.

Brown, Robert McAfee. Frontiers for the Church Today. New York: Oxford University Press, 1973.

Burkhart, Roy A. The Person You Can Be. New York: Harper and Row, 1962. 
Caemmerer, Richard R. The Church in the World. St. Louis: Concordia Pub. House, 1949.

Calabreese, Alphonse and Proctor, William. The Christian Love Treatment. Garden City, New York: Doubleday and Company, 1976.

Campolo, Anthony, Jr. A Denomination Looks at Itself. Valley Forge: Judson Press, 1971.

Chitwood, B. J. What the Church Needs Now: A P1an for Renewa1. o1d Tappan, N. J.: Flemming H. Revell Co., 1973.

Christensen, James L. How to Increase Church Attendance. Westwood, N.J.: Fleming H. Reve11 Co., 1961.

- Don't Waste Your Time in Worship. Old Tappan, N.J.: F1emming H. Reve11 Co., 1978.

Clemons, William and Hester, Harvey. Growth through Groups. Nashville: 'Broadman Press, 1974.

Comis, Arthur W. and Snygg, Donald. Individual Behavior: A Perceptual Approach to Behavior. New York: Harper, 1959.

Cosby, Gordon. Handbook for Mission Groups. Waco, Texas: Word Books, 1975.

Currie, Robert. Methodism Divided: A Study in the Sociology of Ecumenicalism. London: Faber and Faber, 1968.

Des Portes, E1isa R. Congregations in Change. New York: Seabury Press, 1973.

Detamore, Fordice. Seeking His Lost Sheep. Nashville: Southern Pub. Assn., 1965.

Dudley, Carl S. Where Have All Our People Gone? New York: The Pilgrim Press, 1979.

Dudley, Roger E. Why Teenagers Reject Religion. Washington, D.C.: Review and Herald, 1978.

Engel, James F. and Morton, H. Wilbert. What's Cone Wrong with the Harvest. Grand Rapids: Zondervan, 1978.

Engstrom, Ted. W., and Dayton, Edward R. The Art of Mamagement for Christian Leaders. Waco, Texas: Word Books, 1976.

Enns, Arnow. Man, Milieu and Mission in Argentina. Grand Rapids: Wm. B. Eerdmans, 1971. 
Erdman, Charles R. The Epistle of Paul to the rphesians.

Philadelphia: Westminster Press, 1931.

Evans, Louis H., Jr. Creative Love. Old Tappan, N.J.: Flemming H. Reve11 Co., 1977.

Fisher, Wallace E. Preface to Parish Renewal. Nashville: Abingdon Press, 1968.

Elanagan, Donal, ed. The Meaning of the Church. Dublin, Ohio: Gill and Son, 1966.

Flew, R. Newton. Jesus and His Church. London: Epworth Press, reprinted 1960 .

- The Nature of the Church. London: S. C. M. Press, Ltd., 1952 .

Gallup Opinion Index. Religion in America. Reports 70, 114, 130.

Gamble, Paul, and Gamble, Gary. Pastoral Assertiveness: A New Model for Pastoral Care. Nashville: Abingdon, 1978.

Gardner, John W. Self-Renewal. New York: Harper and Row, 1963.

General Conference of Seventh-day. Adventists, Statistical Report, 1978.

Getz, Gene A. Building Up One Another. Wheaton, Ill.: S. P. Publications, 1979 .

- Sharpening the Focus of the Church. Chicago: Moody Press, 1954.

- The Measure of the Church. Glendale: Regal Books, 1973.

Glock, Charles Y., and Stark, Rodney. Religion and Society in

Tension. Chicago: Rand McNally, 1965.

Gore, Charles. St. Paul's Epistle to the Ephesians. London: John Murray, 1967.

Green, Michael. Evangelism in the Early Church. Grand Rapids: Wm. B. Eerdmans, 1976 .

Greeves, Frederic. Theology and the Care of Souls. New York: Channel Press, 1962 .

Halverson, Richard C. How I Changed My Thinking about the Church. Grand Rapids: Zondervan Pub. House, 1972.

Havlick, John F. Pcople-centered Evangelism. Nashville: Broadman Press, $197 \overline{1 .}$ 
Hinson, Glenn H. The Integrity of the Church. Nashville: Broadman Press, 1978.

Hoefler, Richard Carl. Creative Preaching and Oral Writing. Lima, Ohio: The C.S.S. Pub. Co., 1978.

Horn, Henry E. Worship in Crisis. Philadelphia: Fortress Press, 1972.

Howard, Walden. Nine Roads to Renewal. Waco, Texas: Word Books, 1967.

Hunter, George III. The Contagious Congregation. Nashville: Abingdon, $197 \overline{9}$.

Hurlock, Elizabeth B. Developmental Psychology. New York: McGraw Hill Book Co., 1975 .

Jacobsen, Marian Leach. Crowded Pews, Lonely People. Wheaton, I11.: Tyndale House Pub., 1975.

Jenkins, Daniel. Beyond Religion. Philadelphia: Westminster Press, 1962 .

Jud, Gerald J.; Dills, Edgard W. Jr.; and Burch, Genevieve Walters. Ex-Pastors: When Men Leave the Parish Ministry. Philadelphia: Pilgrim Press, 1976.

Kelley, Dean M. Why Conservative Churches are Growing. New York: Harper and Row, 1972 .

Kilinski, Kenneth K., and Wofford, Jerry C. Organization and Leadership in the Local Church. Grand Rapids: Zondervan, 1973.

King, Morton B., and Hunt, Richard A. Measuring Religious Dimensions: Dallas: Southern Methodist University Printing Dept., 1972.

Kraus, Norman C. The Community of the Spirit. Grand Rapids: $\mathrm{Wm}$. B. Eerdmans, 1974 .

Kuiper, R. D. The Glorious Body of Christ. London: The Manner of Truth Trust, 1966.

Kurtz, Arnold. Leadership for Church Organization. Berrien Springs, Michigan: Andrews University, 1979.

Lambie, Thomas A. The Church, the Body of Christ. New York: Fleming H. Revel1 Co., 1946.

Lawson, I,eRoy, and Yamamori, Tetsunao. Church Crowth: Everybody's Business. Cincinnati: Standard Publishing Co., 1975. 
Lecky, Robert S., and Wright, E1liot H. Can These Bones Live? New York: Sheed and Ward, 1969.

Leas, Speed, and Kittlaus, Paul。'Church Fights. Philadelphia: The Westminster Press, 1973.

Linthicum, Robert C. Christian Revolution for Church Renewal. Philadelphia: The Westminster Press, 1972.

Lindgren, Alvin J., and Shawchuck, Norman. Management for Your Church. Nashville: Abingdom Press, 1978.

Luecker, Erwin E. Change and the Church. St. Louis: Concordia Pub. House, 1969 .

Mains, David. Fu11 Circle. Waco, Texas: Word Books, 1971.

Martin, Noah S. Beyond Renewal. Scottdale, Pa.: Herald Press, 1976.

McCabe, Herbert. "The Church and the World." In The Meaning of the Čhurch, pp. 55-71. Edited by Donald Flanagan. Dublin, Ireland: Gill and Son, 1966.

McGavran, Donald, and Arn, W. C. Ten Steps for Church Growth. New York: Harper, 1977.

- Understanding Church Growth. Grand Rapids: Wm. Eerdmans, 1970.

McNutt, William Ray. Worship in the Churches. Philadelphia: The Judson Press, 1941.

Mead, Loren S. New Hope for Congregations. New York: The Seabury Press, 1972 .

Meyer, F. B. Ephesians, a Devotional Commentary. Grand Rapids: Zondervan, 1953.

Montgomery, Warwick John. Damned through the Church. Minneapolis: Bethany Fellowship Inc., 1976.

Munger, Robert. "Purpose, Priority and Planning as.Factors of Renewal of a Local Congregation." Syllabus for Seminar on Church Renewa1. Grand Rapids, July 1979.

Nelson, William R., and Lincoln, William F. Journey Toward Renewal. Valley Forge, Pennsylvania: Judson Press, 1971.

Niebuhr, Richard H. Christ and Culture. New York: Harper and Brothers, 1951 . 
- The Social Sources of Denominationalism. New York: Meridian Books, 1957.

o'Connor, Elizabeth. Journey Inward, Journey Outward. New York: Harper and Row, 1966.

Odiorne, George S. MBO II (Management by Objectives). Belmont, Calif.: Fearon Pitman Pub., 1979.

Parker, Sidney B. The Problem of Church Dropout. - New York: Vantage Press, 1971.

Patterson, Bob E. The Stirring Giant. Waco, Texas: Word Books, 1971 .

Perry, Lloyd. Getting the Church on Target. Chicago: Moody Press, 1977.

Pinson, William Jr., "The Total Dimension in Renewal." In Resources for Renewal, pp. 53-62. Edited by George L. Worrell. Nashville: Broadman Press, 1975.

Raines, Robert. New Life in the Church. New York: Harper, 1961.

Read, Wil1iam; Monterroso, Victor; and Johnson, Harmon Ao Latin American Church Growth. Grand Rapids: Wm. B. Erdmans, 1969.

Rietz, Rudiger. The Church in Experiment. Nashville: Abingdon Press, 1969.

Richards, Lawrence 0 . A New Face for the Church. Grand Rapids: Zondervan Pub. House, 1970.

- Three Churches in Renewal. Grand Rapids: Zondervan Pub. House, 1975.

Roberson, Roland. The Sociological Interpretation of Religion. Oxford: Basil Blackwell, 1970.

Rose, Stephen, ed. Who is Killing the Church? New York: Association Press, 1966.

Seifert, Harvey. New Power for the Church. Philadelphia: Westminster Press, 1976.

Snyder, Howard A. The Community of the King. Downers Grove, 111.: Inter-Varsity Press, 1978.

- The Problein of Wineskins. Downers Grove, I11.: InterVarsity Press, 1978. 
Stammler, Eberhard. Churchless Protestants. Philadelphia: Westminister Press, 1964.

Thurneysen, Edward. A Theology of Pastora1 Care. Richmond, Virginia: John Knox Press, 1962.

Tippett, Allan R. Church Growth and the Word of God. Grand Rapids: Wm. H. Eerdinans, 1970

Troeltsch, Ernst. The Social Teachings of the Christian Churches. New York: Harper and Row, 1960.

Visser't Mooft, W. A. The Renewal of the Church. Philadelphia: The Westminster Press, 1957.

Wagner, Peter C. Your Spiritual Gifts Can Help Your Church Grow. Glendale, Calif.: Regal Books, 1979. - Your Church Can Grow. Glendale, Calif.: Regal Books, 1976.

Wesson, Anthony J., ed. Experiments in Renewal. London: Epworth Press, 1971 .

White, E1len G. Christian Service. Takoma Park, Washington, D.C.: Home Missionary Dept. of the Seventh-day Adventist Church, 1947.

- Evangelism. Washington, D.C.: Review and Herald Pub. Assn., 1946 .

- Fundamentals of Christian Education. Nashville: Southern Pub Assn., 1923.

- Gospel Workers. Washington, D.C.: Review and Herald Pub. Assn., 1916.

- Testimony Treasures. 3 vols. Mountain View, Calif.: Pacific Press Pub. Assn., 1949.

White, James F. Christian Worship in Transition. Nashville: Abingdon, 1970.

Wilson, John. Religion in American Society. Englewood C1iffs, N.J.: Prentice Hall, Inc., 1978.

Wise, Carrol A. The Meaning of Pastoral Care. New. York: Harper and Row, 1966.

Worley, Robert C. $\Lambda$ Gathering of Strangers. Philadelphia: The Westminster Press, 1976. 
- Change in the Church: $\Lambda$ Source of Hope. Philadelphia: The Westminster Press, 1971.

- Dry Bones Breathe! Chicago: The Brethren Press, 1976.

Worrel1, George E. Resources for Renewal. Nashville: Broadman Press, 1975.

\section{Periodicals}

Aeschlimann, Alfredo. "La Responsabilidad del Pastor Hacia los Nuevos Conversos." El Ministerio Adventista, Marzo-Abril, 1979, pp. 9-15.

General Conference of SDA. "Annual Council Action on Evangelism and Finishing God's Work." The Ministry, December 1976, pp. 3-10.

Jones, V. "Attitude of College Students and Their Change: A 37-Year Study." Genetic Psychological Monograph 31 (1970): 3-80.

Teel, Charles, Jr. "How to Be a Movement, Not a Machine." Spectrum, Spring, 1975, p. 49.

World Vision International. "Danger!" Christian Leadership Letter, December 1977.

\section{Theses}

Bonz, Charles C。 "Congregational Self-Study。" Ph.D. dissertation, Columbia Theological Seminary, Decatur, Georgia, 1972.

Nielsen, Louis C。 "Disassociation: An Investigation into the Contributing Factors of Backsliding and Separation from the SDA Church in Michigan." D.Min Project, Andrews University, 1977.

Smuts, James H. "An Examination of the Reasons Leading Individuals to Apostatize." M.A. thesis, The Seventh-day Adventist: Theological Seminary, Washington, D.C., 1950. 
VITA

Name: Ruben Pereyra

Date and Place of Birth: February 18, 1933, Rivera, Uruguay

Undergraduate and Graduate Schools Attended:

Colegio Adventista'de Chile, Chillán, Chile

Colegio Adventista del P1ata, Entre Ríos, Argentina

Andrews University, Berrien Springs, Michigan

Degrees Awarded:

1953 Bachiller en Teología, Colegio Adventista de Chile 1976 Licenciado en Teolog1a, Colegio Adventista del Plata

1979 Master of Arts (and M.Di.v. equivalency)

Andrews University

1980 Doctor of Ministry, Andrews University

Experience:

1954-1960 Pastoral ministry, South Chile Conference of Seventh-day Adventists

1961-1963 Pastoral ministry, Central Chile Conference of Seventh-day Adventists

1963-1964 Mission Evangelist, Lake Titicaca Mission of Seventh-day Adventists

1964-1969 Ministerial Secretary and Evangelist, Inca Union of Seventh-day Adventists

1969-1978 Ministerial Secretary and Evangelist, South American Division of Seventh-day Adventists

1970-1979 Editor of E1 Ministerio Adventista (Spanish) and o Ministerio Adventista (Portuguese) 




\begin{abstract}
A PROCESS OF SELF-ASSESSMENT AND GOAL SETTING FOR A LATIN-AMERICAN LOCAL CONGREGATION AS A POSSIBLE MEANS TO CREATE THE NECESSARY CONDITIONS FOR CHURCH RENEWAL, FRUTTFUL EVANGELISM, AND EFFECTIVE NURTURE
\end{abstract}

by

Ruben Pereyra

Chairperson: Werner Vyhmeister 


\title{
ABSTRACT OF GRADUATE STUDENT RESEARCH \\ Project Report
}

\author{
Andrews University \\ Seventh-day Adventist Theological Seminary
}

Title: A PROCESS OF SELF-ASSESSMENT AND GOAL SETTING FOR A LATINAMERICAN LOCAL CONGREGATION AS A POSSIBLE MEANS TO CREATE THE NECESSARY CONDITIONS FOR CHURCH RENEWAL, FRUITFUL EVANGELISM, AND EFFECTIVE NURTURE

Name of researcher: Ruben Pereyra

Name and title of faculty adviser: Werner Vyhmeister, Ph.D.

Date completed: May 1980

\section{Problem}

Dropouts from church membership have increased during the 1960s among Christian denominations. Abundant literature has been circulating analyzing possible causes and suggesting remedies. The picture is not yet clear. Meanwhile, several types of solutions have been proposed and tried with different degrees of success or failure.

As the issue is also a concern among Seventh-day Adventists, a program considering the particular situation of this denomination, 
in a Latin-American setting, is presented. One way to a renewal experience that would help confirm members and thus prevent dropouts is suggested.

Method

As a first step, a review of the current literature has been made to evaluate the different suggestions given and methods used to increase accessions and reduce apostasies. Further, a program based on a self-assessment process and followed by goal setting and continuous evaluation that can be applied to a local congregation is outlined.

The thesis of the project has been tested in two local congregations of Texas。 In order to search for areas where improvement is necessary, three different surveys were conducted among present and former members of the participating congregations. The analysis of findings of these experiences is made in the project; some conclusions have been drawn and these are estimated as applicable also to other circumstances and situations.

\section{$\underline{\text { Results }}$}

By the end of the program, the churches involved in the pilot test had a clear idea of their needs and had outlined ways and means to satisfy them. The goal setting became the starting point for a reformation in the life of the congregations. According to the studies conducted, improving fellowship, the quality of worship, and preaching were among the priorities of the congregations involved. 


\section{Conclusions}

After the literature about the issue was reviewed and the field tests were conducted, a twofold remedy for facing the problem of dropouts was proposed: (1) the church family must discover a true picture of itself and search for identification of weak areas, and (2) a dedicated effort must be made to face the shortcomings and search for improvement.

The renewal of the internal climate of the church, the quality of relationship among members, and an improvement of the quality of worship and preaching would transform the congregation into a source of spiritual power and affirmation. This would result in more accessions and fewer apostasies. 